\title{
Regional Impacts of Russia’s Accession to the World Trade Organization
}

\section{Thomas Rutherford, University of Colorado David Tarr, The World Bank}

\begin{abstract}
In this paper we develop a computable general equilibrium model of the regions of Russia to assess the impact of accession to the World Trade Organization (WTO) on the regions of Russia. We estimate that the average gain in welfare as a percentage of consumption for the whole country is 7.8 percent (or 4.3 percent of consumption); we estimate that three regions will gain considerably more: Northwest (11.2 percent), St. Petersburg (10.6 percent) and Far East (9.7 percent). We estimate that the Urals will gain only $6.2 \%$ of consumption, considerably less than the national average. The principal explanation in our central analysis for the differences across regions is the ability of the different regions to benefit from a reduction in barriers against foreign direct investment. The three regions with the largest welfare gains are clearly the regions with the estimated largest shares of multinational investment. But the Urals has attracted relatively little FDI in the service sectors. An additional reason for differences across regions is quantified in our sensitivity analysis: regions may gain more from WTO accession if they can succeed in creating a good investment climate.
\end{abstract}

World Bank Policy Research Working Paper 4015, September 2006

The Policy Research Working Paper Series disseminates the findings of work in progress to encourage the exchange of ideas about development issues. An objective of the series is to get the findings out quickly, even if the presentations are less than fully polished. The papers carry the names of the authors and should be cited accordingly. The findings, interpretations, and conclusions expressed in this paper are entirely those of the authors. They do not necessarily represent the view of the World Bank, its Executive Directors, or the countries they represent. Policy Research Working Papers are available online at http://econ.worldbank.org.

This paper was prepared at the request of the Government of the Russian Federation to the World Bank. We gratefully acknowledge financial support from the United Kingdom's Department for International Development. We thank Oleksandr Shepotylo for help with the data and estimates of parameters in this paper and Maria Kasilag for help with the logistics. 


\title{
Regional Impacts of Russia's Accession to the WTO
}

\author{
by \\ Thomas Rutherford and David Tarr
}

\section{Introduction}

Russia is the largest economy in the world that is not a member of the World Trade Organization. Russia applied for membership in the General Agreement on Tariffs and Trade (GATT) in June 1993 and the GATT Working Party was transformed into the World Trade Organization (WTO) Working Party in 1995. President Vladimir Putin has made WTO accession a priority for Russia, and after languishing for several years, the Russian accession negotiations began to see real progress under his administration.

In response to numerous calls for a quantitative assessment of the impact of WTO accession on Russia, Jensen, Rutherford and Tarr (forthcoming) have estimated the economy-wide and sector impacts of Russian WTO accession. While this paper has been helpful in identifying the sectors likely to expand and contract and the reasons for the gains to Russia from WTO accession, geographically Russia is the largest country in the world. There are parts of European Russia close to markets of Western Europe and parts of Far Eastern Russia that are close to the markets of China and Japan, while large portions of Siberia are relatively isolated. We can expect the impacts across the regions to be very diverse, even for the same industry. Consequently, there is a need for a model of Russia that distinguishes its regions.

In this paper we develop a ten region model of Russia for the purpose of assessing the impacts across these ten regions. The structure of the model for each region follows the general structure of the national model of Jensen, Rutherford and Tarr. In particular, we allow foreign direct investment in the business services sectors in each region. We also allow for imperfect competition where the sectors that use goods or services produced under imperfect competition obtain endogenous productivity effects from additional varieties of goods or services (the Dixit-Stiglitz framework).

We present results and explain the economic intuition for these results from a computable general equilibrium model that we believe is appropriate to evaluate the regional impacts of Russian accession to the WTO. We argue that the gains to Russia from WTO accession will derive from three principal effects, which are, in order of importance:

(1) Liberalization of barriers to foreign direct investment in services. A growing body of evidence and economic theory suggest that the close availability of a diverse set of business services is important 
for economic growth. ${ }^{1}$ The key idea in the literature is that a diverse set (or higher quality set) of business services allows users to purchase a quality adjusted unit of business services at lower cost. Russian commitments to multinational service providers will encourage them to increase foreign direct investment to supply the Russian market. Russian businesses will then have improved access to the services of multinational service providers in areas like telecommunication, banking, insurance, transportation and other business services. This should lower the cost of doing business in Russia, increase productivity of Russian firms using these services and generally improve the competitiveness of the Russian economy. However, the regions of Russia vary widely in their capacity to attract foreign direct investment. Differences in results across regions depend to a significant extent on their attractiveness as a location for FDI.

(2) Russian tariff reduction. Tariff reduction will lead to improved domestic resource allocation since tariff reduction induces the country to shift production to sectors where production is valued more highly based on world market prices. This impact, known as the "gains from trade" is a fundamental effect from trade liberalization and is often stressed by international trade economists in the literature. In addition, Russian businesses will be able to more easily import modern technologies or a greater variety of technologies and this will increase Russian productivity. As we show, this second impact is more important. $^{2}$

(3) Improved access to the markets of non-CIS countries in selected products. Russia has already negotiated most-favored nation (MFN) status on a bilateral basis with most of its important trading partners, so Russia's exporters will not see an immediate reduction in the tariffs they face and this effect may not be expected to be large. But Russia will have improved rights under antidumping and

\footnotetext{
${ }^{1}$ As early as the 1960s, the urban and regional economics literature (e.g., Jacobs, 1969; Chinitz 1961; Vernon 1960; Stanback, 1979) recognized the importance of non-tradable intermediate goods (primarily producer services produced under conditions of increasing returns to scale) as an important source of agglomeration externalities which account for the formation of cities and industrial complexes, and explanations of the difference in economic performance across regions. The more recent economic geography literature (e.g., Fujita, Krugman and Venables, 1999) has also focused on the fact that related economic activity is economically concentrated due to agglomeration externalities (e.g., computer businesses in Silicon Valley, ceramic tiles in Sassuolo, Italy). Evidence comes from a variety of sources. Ciccone and Hall (1996) show that firms operating in economically dense areas are more productive than firms operating in relative isolation. Caballero and Lyons (1992) show that productivity increases in industries when output of its input supplying industries increases. Hummels (1995) shows that most of the richest countries in the world are clustered in relatively small regions of Europe, North America and East Asia, while the poor countries are spread around the rest of the world. He argues this is partly explained by transportation costs for inputs since it is more expensive to buy specialized inputs in countries that are far away for the countries where a large variety of such inputs are located.

${ }^{2}$ Romer (1994) has emphasized that the impact of trade liberalization on new or higher quality products is much more important quantitatively than improved resource allocation.
} 
countervailing duty investigations in its export markets, which is the source of the improved access we model. ${ }^{3}$

Our aggregate results for each region are summarized in table 13a. Our central estimates are that the overall gains to Russia from WTO accession are 7.8 percent of Russian consumption (or 4.3 percent of GDP). While the average gain in welfare as a percent of GDP for the whole country is 4.3 percent, we estimate that three regions will gain considerably more: Northwest (6.2 percent), St. Petersburg (5.7 percent) and Far East (5.2 percent). The principal explanation for the differences across regions is the ability of the different regions to benefit from a reduction in barriers against foreign direct investment. The four regions with the largest welfare gains are clearly the regions with the estimated largest shares of multinational investment. All have estimated multinational shares of the service sector that are twice the national average in maritime services, rail services, truck services, air transportation services, telecommunications, science and financial services. On the other hand, we estimate that the Urals will gain only 3.3\% of GDP, considerably less than the national average. But the Urals has relatively little FDI in the services sectors.

We observe that the reduction in barriers to FDI alone results in an improvement in Russian welfare on average across regions of 6.7 percent of consumption (or 3.7 percent of GDP). Improved market access and tariff reduction contribute an improvement in Russian welfare by 0.3 percent and 0.7 percent of consumptioni, respectively, or a combined one percent. Thus, by far the most important effect derives from the reduction in barriers to FDI in services. We also simulate a reduction in the barriers to FDI in business services of only fifty percent of the cuts we assume in our WTO scenario. The gains in Russian welfare are substantially reduced to 4.2 percent of consumption, which again shows the importance of reducing barriers to FDI in order to increase Russian productivity, competitiveness and welfare. Thus, the estimated gains from FDI liberalization are almost three-quarters of the total gains from Russian WTO accession. Thus, while improving its offer to foreign services providers within the context of the GATS has been one of the most difficult aspects of Russia's negotiation for WTO accession, our estimates suggest that the most important component of WTO accession for Russia in terms of the welfare gains is liberalization of its barriers against FDI in services sectors.

In the sensitivity analysis, we also incorporate data on the investment potential of regions based on the investment potential rankings of Expert RA. The principal result is that the estimated gains for Moscow, St. Petersburg and Tumen increase and the estimated gains for Siberia, Northwest, North,

\footnotetext{
${ }^{3}$ WTO accession will grant an "injury determination" to Russia in antidumping cases in WTO members countries. Combined with the decision by the US and the EU to treat Russia as a market economy this will imply Russian exporters may have considerably improved rights in these cases in the US. But market economy status may be denied in particular cases, so it will be necessary to see how this is implemented in practice.
} 
Central and the Far East decline. Despite smaller estimated gains in this scenario, Far East and Northwest are still estimated to receive above average gains. The results suggest that the gains for a region could vary considerably depending on whether it succeeds in creating an atmosphere conducive to investment.

Our estimates show that many of our Russian goods sectors should expand and employment in many services sectors expands. This occurs despite the reduction in all tariffs by 50 percent and a reduction in barriers against foreign direct investment in business services. Whether a sector expands or contracts depends on what happens to the incentives of one sector versus another. Economy-wide, Russia will see an increase in exports equal to the increase in imports. The expansion in exports occurs because Russia will have to pay for additional imports through hard currency, which increases the demand for hard currency and causes a real depreciation of the ruble. A depreciated ruble makes exporting more profitable and decreases the demand for imports until the additional exports are equal to the additional imports. The export intensive sectors tend to gain the most from ruble depreciation.

In goods sectors, we estimate that the ferrous metals, non-ferrous metals and chemicals sectors are the goods sectors that expand the most. These are the sectors that export the most intensively. They also experience a terms of trade gain from improved treatment in antidumping cases. We estimate that food, machinery and equipment and construction materials will decline as these sectors export relatively less and are relatively highly protected.

In business services, employment effects vary across sectors, with some expanding (multinationals will demand Russian labor when they locate in Russia and the demand for business services increases) and some contracting demand for labor (since multinationals use Russian labor less intensively than Russian companies). But users of business services will become more internationally competitive as they obtain an increase in the quality and diversity of available competitively priced business services.

This paper quantifies and supports the views expressed by the some in the government that when all changes are taken into account, many goods sectors would expand, despite a reduction in their tariff.

The paper is organized as follows. In section II, we describe the model and the most important data. In section III, we describe and interpret the policy scenarios and quantitatively assess the sensitivity of the results to parameter assumptions. Many of the scenarios we describe are decomposition scenarios that allow us to assess the relative importance of the various aspects that we consider important to Russian WTO accession. We provide sensitivity analysis in section IV and briefly conclude in section V. 


\section{Overview of the Model and Key Data}

\section{Production and Geographic Structure}

There are 30 sectors in the model that are listed in table 1 . There are three types of sectors: perfectly competitive goods and services, imperfectly competitive goods sectors and imperfectly competitive business services sectors.

The geographic decomposition of our model of Russia is shown in table 2. In the first instance, we obtain data from the publication the Regions of Russia by Rosstat on 88 regions of Russia. The 88 regions have several names in Russian; the most common legal jurisdiction is referred to in Russian as an “oblast.” Oblasts are analogous to states in the United States or provinces in Canada. But there are also jurisdictions known as territories, federal cities, autonomous districts and an autonomous region. Since we want to use the term "region" for another purpose in the model, we use the Russian term "oblast" for all of these 88 geographic areas, ${ }^{4}$ with the understanding that they are not all oblasts in the Russian sense of the term.

We group several contiguous oblasts into what we call Regional Markets (RMs). The mapping of oblasts into regional markets is also shown at the top of table 2. In this paper, we shall analyze effects at the level of the Regional Market. Value-added, exports and imports by sector for our ten regions of Russia are presented in tables 3-11.

We assume that firms and sectors operate at the Regional Market level, primary factors of production are not able to move between Regional Markets (unless otherwise notes). We assume a nested CES structure of demand. Since this implies that the structure of demand is both a homothetic and weakly separable, consumers and firms in a representative Regional Market r employ multiple stage budgeting for all goods.

\section{Price determination for competitive goods and services sectors}

Firms in each Regional Market have three choices for sales: sell in their own Regional Market; sell to other parts of Russia; or export to the rest of the world. This is depicted in figure 1. Firms maximize revenue for any given output level based on their transformation possibilities between the three types of goods which is defined by a constant elasticity of transformation production function. For all firms within the same Regional Market, the product they export to other parts of Russia (including other oblasts within their own regional market) is homogeneous. It follows from our assumptions of

\footnotetext{
${ }^{4}$ Several of the territories are part of oblasts, so it was necessary to adjust the data to avoid double counting of the territories.
} 
homogeneous demand and production outside of the own Regional Market, that for each competitive good, say good g, there will be only three prices for good g of Regional Market r: the price of good g in Regional Market $r$; the price of good g from Regional Market $r$ in other parts of Russia; and the price of good g from Regional Market $r$ in the rest of the world.

The structure of demand for goods or services from competitive sectors is shown in figure 2. Consumers and firms in a representative Regional Market $r$ first optimize their choice of expenditures on foreign goods versus goods from Russia. Subsequently they optimally allocate their expenditures between goods from other Russian Regional Markets and their own Regional Market. Finally, they optimally allocate their expenditures between goods from the other Russian Regional Markets. This structure assumes that consumers differentiate the products of producers from different regional markets; but, they regard as homogeneous the products of producers from different oblasts within the same regional market.

\section{Goods produced subject to increasing returns to scale}

The structure of demand for goods produced under increasing returns to scale is shown in figure 3. Consumers (and firms) in RM r, optimally allocate expenditures on good g among the goods available from the different regional markets of Russia and the rest of the world producers. Having decided how much to spend on the products from each regional market, consumers then allocate expenditures among the producers within each regional market. Since we assume identical elasticity of substitution at all levels, this is equivalent to firm level product differentiation of demand. That is, the structure is equivalent to a single stage in which consumers decide how much to spend on the output of each firm in the first stage of optimal allocation of expenditure.

We assume that imperfectly competitive manufactured goods may be produced in each region or imported. Both Russian and foreign firms in these industries set prices such that marginal cost (which is constant) equals marginal revenue in each regional market. There is a fixed cost of operating in each region and there is free entry, which drives profits to zero for each firm on its sales in each regional market in which it sells. Quasi-rents just cover fixed costs in each region in the zero profit equilibrium. We assume that all firms that produce from the same regional market have the same cost structure- the standard symmetry assumption.

Foreigners produce the goods abroad at constant marginal cost but incur a fixed cost of operating in each RM in Russia. The cif import price of foreign goods is simply defined by the import price; by the zero profits assumption, in equilibrium the import price (less tariffs) must cover fixed and marginal costs that foreign firms incur in each regional market. 
Similar to foreign firms, Russian firms also produce their goods in their home regions; they incur a fixed cost of operation if each RM in which they operate. By the zero profit constraint, if they operate in a RM, the price of their product must just cover both fixed and marginal costs of operation in that RM.

In figure 4, we depict the structure of production for imperfectly competitive Russian firms. Regional firms use intermediate inputs (which can be foreign inputs, inputs from other regions of Russia or from its own region) and primary factors of production to produce output. We emphasize that business services are not part of the "other services” nest; rather business services substitute for primary factors of production in a CES nest. ${ }^{5}$ We show that the elasticity of substitution between business services and primary factors of production significantly impacts the results.

We assume that Russian firms do not have any market power on world markets and thus act as price takers on their exports to world markets. On the exports to the rest of the world then, price equals marginal costs. On sales to Russia, firms must use a specific factor in addition to the other factors of production. The existence of the specific factor implies that additional output or firms can only come at increasing marginal costs. Imperfectly competitive Russian goods producers sell in all of Russia; but services firms do not sell in other Russian regional markets.

We employ the standard Chamberlinian large group monopolistic competition assumption within a Dixit-Stiglitz framework, which results in constant markups over marginal cost. For simplicity we assume that the composition of fixed and marginal cost is identical in all firms producing under increasing returns to scale (in both goods and services). This assumption in a Dixit-Stiglitz based Chamberlinian large-group model assures that output per firm for all firm types remains constant, i.e., the model does not produce rationalization gains or losses.

An increase in the number of varieties increases the productivity of the use of imperfectly competitive goods based on the standard Dixit-Stiglitz formulation. Dual to the Dixit-Stiglitz quantity aggregator is the Dixit-Stiglitz cost function which shows the productivity adjusted cost of using the available varieties in the regional market when varieties are purchased at minimum cost for a given output level. This cost function for users of goods produced subject to increasing returns to scale declines in the total number of firms in the industry. The lower the elasticity of substitution, the more valuable is an additional variety.

We have assumed that imperfectly competitive firms within a regional market have symmetric cost structures and face symmetric demand for their outputs. It follows from these assumptions that all

\footnotetext{
${ }^{5}$ For example, firms can employ an accountant or a lawyer, or contract for accounting or legal services. They can employ a driver and buy a truck, or contract for delivery services. These examples make it evident that it is more appropriate to allow substitution between business services and primary factors of production than to assume a Leontief structure.
} 
imperfectly competitive firms from a regional market will obtain the same price in any regional market of Russia in which they operate, although the price will differ across regional markets since the fixed costs associated with entering any regional market varies across the regional markets.

\section{Services sectors that are produced in Russia under increasing returns to scale and imperfect competition}

These sectors include telecommunications, financial services, most business services and transportation services. In services sectors, we observe that some services are provided by foreign service providers on a cross border basis analogous to goods providers from abroad. But a large share of business services are provided by service providers with a domestic presence, both multinational and Russian. ${ }^{6}$ As shown in figure 5, our model allows for both types of foreign service provision in these sectors. There are cross border services allowed in this sector and they are provided from the firms outside of Russia at constant costs - this is analogous to competitive provision of goods from abroad. Cross border services from the rest of the world, however, are not good substitutes for service providers who have a presence within the regional market of Russia where consumers of these services reside. ${ }^{7}$

Russian firms providing imperfectly competitive business services operate at the regional level and organize production in a manner fully analogous to imperfectly competitive Russian firms producing goods. Thus, figure 4 applies to both Russian imperfectly competitive goods and services firms. Other assumptions we made for imperfectly competitive goods producers, such as entry conditions, pricing and symmetry are also apply to imperfectly competitive services providers. The only difference is that we assume that regional services providers sell only in their own regional market. It follows from these assumptions that there is a unique price for all Russian providers of imperfectly competitive business services in a regional market.

There are also multinational service firm providers that choose to establish a presence in a RM of Russia in order to compete with regional Russian firms directly in the Russian Regional Market. The decision to locate in a regional market by a multinational must take into account the existence of a fixed cost of operating in a regional market. As with imperfectly competitive goods producers, quasi-rents must cover the fixed plus marginal costs of producing in a regional market and we have a zero profit equilibrium.

\footnotetext{
${ }^{6}$ One estimate puts the world-wide cross-border share of trade in services at $41 \%$ and the share of trade in services provided by multinational affiliates at 38\%. Travel expenditures $20 \%$ and compensation to employees working abroad $1 \%$ make up the difference. See Brown and Stern (2001, table 1).

${ }^{7}$ Daniels (1985) found that service providers charge higher prices when the service is provided at a distance.
} 
When multinational service providers decide to establish a domestic presence in a regional market of Russia, they will import some of their technology or management expertise. That is, foreign direct investment generally entails importing specialized foreign inputs. Thus, the cost structure of multinationals differs from Russian service providers. Multinationals incur costs related to both imported primary inputs and Russian primary factors, in addition to intermediate factor inputs. Foreign provision of services differs from foreign provision of goods, since the service providers use Russian primary inputs. This is shown in figure 6, where we show multinationals combining imported primary inputs with inputs of the service good from the oblasts within the regional market. Domestic service providers do not import the specialized primary factors available to the multinationals. Figure 4 for Russian business service providers is analogous to figure 6 for multinational service providers except for the nest for imported primary inputs. Foreign service providers also must use a specific factor to produce the output and this implies that additional output can only be obtained at increasing marginal costs. Since the structure of costs for all multinational firms that provide a service $\mathrm{s}$ in a given region $\mathrm{m}$ is identical and demand is symmetric, there is a unique price for all multinationals providers of service $\mathrm{s}$ in regional market $\mathrm{m}$.

For multinational firms, the barriers to foreign direct investment affect their profitability and entry. Reduction in the constraints on foreign direct investment in a region will induce foreign entry that will typically lead to productivity gains because when more varieties of service providers are available, buyers can obtain varieties that more closely fit their demands and needs (the Dixit-Stiglitz variety effect).

\section{Factors of Production}

Primary factors include skilled and unskilled labor and three types of capital; (i) mobile capital (within regions); (ii) sector-specific capital in the energy sectors reflecting the exhaustible resource; and (iii) sector specific capital in imperfectly competitive sectors. We also have primary inputs imported by multinational service providers, reflecting specialized management expertise or technology of the firm. The existence of sector specific capital in several sectors implies that there are decreasing returns to scale in the use of the mobile factors and supply curves in these sectors slope up.

The above list of primary factors exist in all regions. In the case of skilled and unskilled labor it is natural to assume that the representative agent in the region obtains the returns from these factors of production. Consistent with standard trade models, in our central model we assume that capital and labor are immobile between regions. However, this model is a regional disaggregation of a national model of Russia; consequently, it does not seem reasonable to assume that all capital in a region is owned by the agents in that region. Thus, we make the assumption that a fraction of the capital in any region is held by agents outside of the region, but the capital is held by residents in the country. We take the fraction of the 
capital held by agents in the region to be 50 percent, but this percentage is not crucial to the solution of the model.

Regarding the capital of each region that is held outside of the region, it is convenient to think of a national mutual fund that holds the remaining capital in each region. For all three capital types ((i) mobile; (ii) specific capital in the energy sectors; and (iii) specific capital in the IRTS sectors) fifty percent of the capital used in the region is owned by this mutual fund and the balance is owned by the representative agent in the region. The national mutual fund invests in all regions and obtains an overall return. The representative agent in the region also holds shares in the national mutual fund. ${ }^{8}$.

For each region we report returns to capital as returns to the three types of regional capital held by the region's representative agent. Plus the region's representative agent obtains a share of the returns from the national mutual fund. The return to national capital is the region's share of the return of the national mutual fund reported as a percentage of initial consumption of the region.

\section{Key Data}

\section{Ad Valorem Equivalence of Barriers to Foreign Direct Investment in Services Sectors}

Among the key restrictions against multinational service providers that have existed or exist in Russia are: the Rostelecom monopoly on long distance fixed-line telephone services (scheduled to be removed), affiliate branches of foreign banks are prohibited, and there is a quota on the multinational share of the insurance market. ${ }^{9}$ Estimates of the ad valorem equivalence of these and other barriers to FDI in services are key to the results. Consequently, we commissioned 20 page surveys from Russian research institutes that specialize in these sectors and econometric estimates of these barriers based on these surveys.

\footnotetext{
8 Define M(r) as the representative agent's share of the returns to the national mutual fund. We calculate M(r) as follows. For each region $r$, the initial consumption income $C(r)$ equals its endowment income $E(r)$ minus the share of the trade surplus $B(r)$ attributed to the region: $C(r)=E(r)-B(r)$. Define $B(r)=[C(r) / C]^{*} B$ where $C$ is aggregate consumption for Russia and $B$ is the aggregate trade surplus. That is, the region's share of the trade surplus is proportional to its share of aggregate consumption.
}

$E(r)$ is defined above, but is also defined as: $E(r)=L(r)+K(r)+M(r)$. That is, endowment income for each region is labor income $\mathrm{L}(\mathrm{r})$; plus capital income on regional capital held by the representative agent in the region $\mathrm{K}($ r); plus the representative agent's share of the returns to the national mutual fund M(r). E(r), L(r) and K(r) are all known. We calculate $M(r)$ residually for each region $r$ as:

$E(r)-L(r)-K(r)=C(r)-B(r)-L(r)-K(r)=M(r)$.

\footnotetext{
${ }^{9}$ The protocol on Russian accession signed between the European Union and Russia on May 21, 2004 calls for the termination of the Rostelekom monopoly by 2007 and allows for an increase in the upper limit on the multinational share of the Russian insurance market.
} 
These questionnaires provided us with data, descriptions and assessments of the regulatory environment in these sectors. ${ }^{10}$ Using this information and interviews with specialist staff in Russia, as well as supplementary information, Kimura, Ando and Fujii (2004a, 2004b, 2004c) then estimated the ad valorem equivalence of barriers to foreign direct investment in several Russian sectors, namely in telecommunications; banking, insurance and securities; and maritime and air transportation services. The process involved converting the answers and data of the questionnaires into an index of restrictiveness in each industry. Kimura et al. then applied methodology explained in the volume by C. Findlay and T. Warren (2000), notably papers by Warren (2000), McGuire and Schulele (2000) and Kang (2000). For each of these service sectors, authors in the Findlay and Warren volume evaluated the regulatory environment across many countries. The price of services is then regressed against the regulatory barriers to determine the impact of any of the regulatory barriers on the price of services. Kimura et al. then assumed that the international regression applies to Russia. Applying that regression and their assessments of the regulatory environment in Russia from the questionnaires and other information sources, they estimated the ad valorem impact of a reduction in barriers to foreign direct investment in these services sectors. ${ }^{11}$ The results of the estimates are listed in table $2 .{ }^{12}$ In the case of maritime and air transportation services, we assume that the barrier will only be cut by 15 percentage points, since pressure from the Working Party in these sectors is not strong.

Share of Expatriate Labor Employed by Multinational Service providers. The impact of liberalization of barriers to foreign direct investment in business services sectors on the demand for labor in these sectors will depend importantly on the share of expatriate labor used by multinational firms. We explain in the results section that despite the fact that multinationals use Russian labor less intensively than their Russian competitors, if multinationals use mostly Russian labor their expansion is likely to increase the demand for Russian labor in these sectors. ${ }^{13}$ We obtained estimates of the share of expatriate labor or specialized technology that is used by multinational service providers in Russia, but which is not

10 This information was provided by the following Russian companies or research institutes: Central Science Institute of Telecommunications Research (ZNIIS) in the case of telecommunications, Expert RA for banking, insurance and securities; Central Marine Research and Design Institute (CNIIMF) for maritime transportation services and Infomost for air transportation services. We thank Vladimir Klimushin of ZNIIS; Dmitri Grishankov and Irina Shuvalova of ExpertRA; Boris Rybak and Dmitry Manakov of InfoMost; and Tamara Novikova, Juri Ivanov and Vladimir Vasiliev of CNIIMF. The questionnaires are available at www.worldbank.org/trade/russia-wto. The same sources provided the data on share of expatriate labor discussed below.

11 Warren estimated quantity impacts and then using elasticity estimates was able to obtain price impacts. The estimates by Kimura et al. that we employ are for "discriminatory” barriers against foreign direct investment. Kimura et al. also estimate the impact of barriers on investment in services that are the sum of discriminatory and nondiscriminatory barriers.

12 See Jensen, Rutherford and Tarr (2006) for an explanation of the estimate in telecommunications.

${ }^{13}$ See Markusen, Rutherford and Tarr (2005) for a detailed explanation on why FDI may be a partial equilibrium substitute for domestic labor but a general equilibrium complement. 
available to Russian firms, from the Russian research institutes that specialize in these sectors. In general, we found that multinational service providers use mostly Russian primary factor inputs and only small amounts of expatriate labor or specialized technology. In particular, the estimated share of foreign inputs used by multinationals in Russia is: telecommunications, $10 \%$ plus or minus $2 \%$; financial services, $3 \%$, plus or minus $2 \%$; maritime transportation, $3 \%$, plus or minus $2 \%$; and air transportation, $12.5 \%$, plus or minus $2.5 \%$.

\section{Tariff and Export Tax data}

Tariff rates by sector are taken from the paper by Tarr, Shepotylo and Koudoyarov (2006). Tarr, Shepotylo and Koudoyarov estimate the tariff rates by sector in our model based on the following data and methodology. For the purpose of calculating the tariff rates, we obtained data on the quantity and value of imports for 2001, 2002 and 2003 from the electronic database of the commercial company Academy-Service. ${ }^{14}$ This dataset provides information on the Russian tariff structure at the tariff line level, i.e., the 10-digit level. The source of information on tariff rates is the Decree of the Government of Russian Federation on import duties \#830. ${ }^{15}$ The decree is available, for example, at www.consultant.ru.

The average MFN tariff in Russia has increased between 2001 and 2003. On an un-weighted simple average basis it increased from $11.6 \%$ to $12.9 \%$; on a weighted average basis it increased from $11.4 \%$ to $14.5 \%$. This average is calculated based on MFN tariffs.

Collected tariffs are less than MFN tariffs because of a several exemptions in the Russian tariff structure. Most notably, CIS imports usually enter tariff free (although there are exceptions to this rule), and personal and private imports also enter tariff free for sufficiently small values of imported shipments. We also provide estimates of the tariff rates where we adjust for zero tariff collections on CIS imports. That is, in our formulas for calculating the tariff on a tariff line, we set ad valorem and specific rates on imports from the CIS countries equal to zero to take into account the special trade regime within the CIS. We call these calculations our estimated collected tariff rates. We find that overall estimated collected tariff rates are lower than the MFN rates by about one percent.

Our overall estimated collected tariff rate was equal to $10.4 \%$ in $2001,10.9 \%$ in 2002, and $11.5 \%$ in 2003. On the other hand, based on Ministry of Finance and Customs Committee data, the actual

\footnotetext{
${ }^{14}$ http://www.ftinform.com

${ }^{15}$ We looked at three editions of the decree: first, dated by 11.30 .2001 for 2001; the second, dated by 02.06 .2003 for 2002 rates, and the third, dated by December 2003 for 2003 rates.
} 
collected rate was $9.5 \%$ in 2001, 9.7\% in 2002, and 9.8\% in 2003. The difference can be attributed to the fact that we did not take into account any exemptions other than the CIS free trade zone exemption. ${ }^{16}$

We believe collected tariff rates more closely approximate the protection a sector receives and the incentives it faces. Using our estimated collected tariff rates, and based on a Rosstat mapping from the tariff line data of the Customs Committee to the sectors in our input output table, we calculated a weighted average tariff rate for the sectors of our model. The results of this procedure for each sector of our model are reported in table 12a.

Export tax rates are calculated from the 2001 input-output table of Rosstat and are reported in table 12a. Since we do not change export taxes in the counterfactual simulations, these parameters are less important to the results than the tariff rates.

\section{Input-output tables}

The core input-output model is the 2001 table produced by Rosstat. The official table contained only 22 sectors, and importantly has little service sector disaggregation. In order to disaggregate the table, we used costs and use shares from our 35 sector Russian input-output table for 1995 prepared by expert S. P. Baranov. (For details see www.worldbank.org/trade/russia-wto.) When we broke up a sector such as oil and gas into oil, gas and oil processing, we assumed that the cost shares and use shares of the sector were the same in 2001 as they were in the 1995 table. For example, steel is an input to the oil and gas sector. Suppose in 1995, that oil purchased 55 percent of the steel used in oil and gas. Then we assume that in 2001, oil purchased 55 percent of the steel used in oil and gas.

\section{Regional IO tables}

We generated input-output tables for the regions based on output data from the regions and the national input-output table. For each industrial sector we took national output from the national inputoutput table for 2001, and we used the data in Regions of Russia to allocate the shares of that output across regions. That is, from the Regions of Russia 2001, we have, by region; industry shares of output for the year 2000 (table 13.3); thousands of tons of oil recovery, including gas condensate, for the year 2000 (table 13.13); extraction of natural gas (in millions of cubic meters for the year 2000, table 13.14); thousands of tons of mined coal for the year 2000 (table 13.15). We also have external exports and imports by region, as well as the commodity structure of exports and imports by region for the year 2001

\footnotetext{
${ }^{16}$ To calculate actual collected rate, we used the Ministry of Finance data on collected import duties as a numerator. As a denominator, we used the overall import volume less import from Belarus as reported by the Russian Customs Committee. The exclusion of the imports from Belarus is determined by the fact that the electronic dataset which we used in the calculations reported import volume without imports from Belarus.
} 
(tables 23.1 and 23.2). We also have unpublished data supplied by Rosstat on exports and imports by sector and by region of Russia.

We assume that the technology of production is common across regions, so that the same input output coefficients apply across all regions. We create an input output table for each region of Russia, where the shares of output and energy for each region are taken from the Regions of Russia and we have common technology across all regions. We infer regional demand (and supply) of services, assuming that intermediate and final demand for services have the same intensity of demand in all regions as in the national model.

We have to adjust the resulting regional import and export intensities so that regional exports in aggregate are consistent with national import and export values. We do not need to make any other adjustments, as the production technologies are assumed consistent across the regions.

\section{FDI Shares}

We explain the methodology further in the appendix, but briefly, we first employed the NOBUS survey to obtain the shares of workers working in multinationals service sectors in each sector in each region. We used this as a proxy for the share of output in each service sector in each region. We also obtained information from (1) our estimates from Russian service sector institutes of the share by sector of multinational ownership in the key services sectors; ${ }^{17}$ (2) Regions of Russia (2003) by Rosstat; and (3) the "BEEPS survey. Only the NOBUS survey provides data that allows us to estimate shares of multinational ownership by both region and sector. We thus start with our calculations based on the NOBUS information.

When found, however, that when we aggregate the NOBUS shares across regions or sectors, the other three sources of information show considerably higher foreign ownership shares than the NOBUS survey. We believe that the NOBUS survey estimates are too small, and adjust them. We adjusted our estimates from the NOBUS to be consistent with the estimates of the service sectors institutes. The service sector institute estimates are lower than those from the BEEPS or Regions of Russia, and thus involve less adjustment of the NOBUS data. We employed least squares adjustment of the NOBUS data so that the weighted average over all of Russia in each sector is consistent with the national estimates we received from the specialist service sector research institutes in Russia. This process will give as a structure of ownership based on the NOBUS survey, with the economy-wide average by sector determined by the national data. Results are presented in table $12 \mathrm{~b}$.

\footnotetext{
${ }^{17}$ We thank the service sectors institutes in Russia mentioned above for these estimates.
} 


\section{Policy Results}

For each of our ten regional markets, we first discuss our central scenario (results are in table 13). In our central scenario, we assume that tariffs on goods are cut by fifty percent, that barriers to foreign direct investment are eliminated or reduced (depending on the sector) and that seven industrial sectors receive an improvement in their market access between $0.5 \%$ and $1.5 \%$. See table $12 \mathrm{a}$ for details by sector. We present the overall welfare effects, the impact on wages and returns to capital, the changes in exports and the real exchange rate and factor adjustment costs. The gains come from a combination of effects, so we also estimate the comparative static impacts of the various components to WTO accession in order to assess their relative importance. We also decompose the results in the components of the gains to provide a transparent explanation of the results. Next we discuss the estimates of the impact at the level of productive sectors of the economy. In order to obtain an assessment of the adjustment costs, we estimate the percentage of mobile labor and capital that must change industries. We also conduct sensitivity analysis with respect to some key parameters and present these results. A key aspect of the sensitivity analysis is how the results differ when we assess the ability of different regions to attract FDI based on the ranking of their investment potential. The sensitivity analysis helps to provide insights into how the gains may differ across regions.

\section{Welfare Effects of WTO Accession}

In table 13a, we show that the weighted average of the welfare gains across all regions is 4.3 percent of GDP or 7.8 percent of consumption. By region, the welfare gains as a percent of GDP range from 3.1 percent in Tumen to 6.2 percent in the Northwest region. Except for Tumen, the gains as a percent of consumption range from 6.2 percent in the Urals regional market to 11.2 percent in the Northwest regional market. The gains to Tumen as a percent of consumption are much higher because a larger share of the GDP of Tumen is invested, so consumption is a smaller share of GDP.

In order to assess what is causing these results we have undertaken several additional simulations in which we allow only one of the components of our WTO scenario to change, while holding others constant. That is we evaluate separately the impact of complete removal of barriers to foreign direct investment in business services, but no other changes; the impact of an increase in market access alone; and a cut tariff barriers only.

Explaining Differences across Regions. While the average gain in welfare as a percent of GDP for the whole country is 4.3 percent, we estimate that three regions will gain considerably more: Northwest (6.2 percent), St. Petersburg (5.7 percent) and Far East (5.2 percent). The principal explanation for the differences across regions is the ability of the different regions to benefit from a reduction in 
barriers against foreign direct investment. Some regions may attract FDI much more easily than others. A key parameter in our model is the initial share of multinational investment in each sector in each region. Multinational firms have widely different shares of the business services sectors in the different regions. A ten percent expansion of multinational firms will be a much larger absolute amount in a region that has substantial FDI initially. Thus, larger initial shares of FDI in a region will lead to larger absolute increases in FDI in the region when the barriers against FDI are reduced.

In table $12 \mathrm{~b}$, we display our estimates of the shares of the industry captured by multinational firms. The three regions with the largest welfare gains are clearly the regions with the estimated largest shares of multinational investment (along with a fourth region, the North region, which also gains substantially). All have estimated multinational shares of the service sector that are twice the national average in maritime services, rail services, truck services, air transportation services, telecommunications, science and financial services. On the other hand, we estimate that the Urals will gain only 3.3\% of GDP, considerably less than the national average. But we see from table $12 \mathrm{~b}$ that the Urals has relatively little FDI in the services sectors, as the Urals share of FDI ranges from about 50 to 70 percent of the national average depending on the sector.

Impact of Foreign Direct Investment Liberalization in Business Services. In this scenario, presented in table 13b, we reduce barriers against FDI in the services sectors according to the cuts in table 12, but there is no reduction in tariffs or improved market access. Russian commitments to reduce barriers against multinational service providers will allow multinationals to obtain greater after tax returns on their investments in Russia. This will encourage them to increase foreign direct investment to supply the Russian market. Although we expect some decline in the number of purely Russian owned businesses serving the services markets, on balance there will be additional service providers. Russian users of businesses services will then have improved access to the providers of services in areas like telecommunication, banking , insurance, transportation and other business services. We have referenced several empirical papers in the introduction which show that availability of a diverse set of service suppliers is crucial to the growth of countries as this should lower the cost of doing business and increase productivity of Russian firms using these services. We estimate that the gains to Russia from liberalization of barriers to FDI in services are about 6.7 percent of the value of Russian consumption or 3.7 percent of the value of GDP. 
Impact of Improved Market Access. In table 13d, we present the results of a scenario in which we allow for improved market access (according to the terms of trade improvements of table 12), but we do not lower tariffs or barriers to FDI in services sectors. We estimate that the impact of improved market access at 0.3 percent of consumption ( $0.2 \%$ of GDP). The gains come from both improved prices for exports. But also a higher value for exports allows Russia to buy more imports and more varieties of imports increase productivity. The gains are quite small compared with the gains from liberalization of barriers against FDI in services. In part this is because the ad valorem equivalent of the barriers against FDI are much higher than the percentage improvement in market access, while Russia already has mostfavored-nation (MFN) status or better on a bilateral or plurilateral basis with virtually all its trading partners.

Improved market access has a small but positive effect on all regions except Tumen. The reason the impact is negative for Tumen is that Tumen exports mainly oil and gas, products that do not gain from the improved market access. The improved market access results in greater exports for the economy, which has the effect of appreciating the real exchange rate, and thereby reducing the value of the principal exports of Tumen. This is analogous to the Dutch disease problem, except it is non-oil and gas exports that are hurting the oil and gas exports in this scenario.

Impact of Tariff Reduction. The results for this scenario are presented in table 13e. We lower tariffs by fifty percent, but there is no liberalization of the barriers to FDI or improved market access. The estimated welfare gains to the economy are 0.7 percent of consumption or 0.4 percent of GDP.

The gains to the economy from tariff reduction alone come about for two reasons. Tariff reduction in Russia will lead to improved domestic resource allocation since tariff reduction will induce Russia to shift production to sectors where production is valued more highly based on world market prices. This impact, known as the "gains from trade" is the fundamental effect from trade liberalization and is often stressed by international trade economists. In addition, Russian businesses will be able to more easily import a variety of modern technologies and this will increase Russian productivity.

Summary of Overall Welfare Effects. We observe that the reduction in barriers to FDI results in an improvement in Russian welfare on average across regions of 6.7 percent of consumption. Improved market access and tariff reduction contribute an improvement in Russian welfare by 0.3 percent and 0.7 percent, respectively, or a combined one percent. Thus, by far the most important effect derives from the reduction in barriers to FDI. We also simulate a reduction in the barriers to FDI in business 
services of only fifty percent of the cuts we assume in our WTO scenario (shown in table 13c). The gains in Russian welfare are substantially reduced which again shows the importance of reducing barriers to FDI in order to increase Russian productivity and welfare.

\section{Impact on the Productive Sectors}

It is useful to discuss principles of sector analysis before discussing the results. Businessmen in Russia sometimes complain that the tariff or FDI barriers in their sector will decline and forecast that WTO accession could adversely impact on their sector. The initial effect of the tariff reduction is to induce an increase in the demand for imports, and this is the immediate impact that businessmen fear. But the rest of the world will not provide Russia with a "free lunch," i.e., the increased imports have to be paid for by increased exports. The increased demand for imports raises the prices of foreign exchange (more technically, depreciates the real exchange rate) that in turn induces an increase in exports and a decrease in the quantity of imports. The real exchange rate depreciates until the value of the increase in exports equals the value of increased imports. The percentage change in the overall value of increased international exports is presented in the table 13a and equals 9.4 percent in our central scenario. ${ }^{18}$ The expansion of exports varies across regions ranging from a low of 2.8 percent from Tumen to a high of 23 percent from the Central region. ${ }^{19}$

Thus, not all sectors can decline since Russia has to pay for its imports with hard currency. It is not the absolute level of the tariff that is important for the impact of WTO accession on the sector; rather it is the impact of changes in protection on relative prices. The tariff reduction induces output expansion in many sectors because, first, tariff reduction reduces the costs of imported intermediate inputs, so the price of intermediate inputs may decline in many sectors. Second, and crucially, tariff reduction induces a depreciation in the real exchange rate.

Similarly, all regions within Russia must pay for their imports, from abroad or from other regions. Analogous to our national model, we assume that each region has a balance of trade constraint such that

\footnotetext{
${ }^{18}$ The change in the value of international exports must equal the change in the value of international imports. Since international exports exceed international imports in the benchmark equilibrium, the percentage change in exports is smaller than the percentage change in imports.

${ }^{19}$ Since the initial value of exports exceeds the initial value of imports in our data set, a smaller percentage increase in exports is equal in absolute dollar value to a larger percentage increase in imports.
} 
any increase or decrease in imports is exactly matched by an increase or decrease in exports. Moreover, total employment in the region is unchanged by the trade or FDI policy changes. Thus, an expansion of employment in one sector must be offset by a decline in employment in another sector.

In tables 15-18, we present the estimated results in particular sectors and region. We present the results for the WTO overall scenario. Our WTO accession scenario involves a proportional reduction in all tariffs to one-half of their original level, improved market access and complete removal of barriers to FDI in services. Results are presented for output, exports, imports and employment of skilled and unskilled labor by sector. We discuss manufacturing and services sectors separately.

Expanding Manufacturing Sectors. Results for the manufacturing sectors that expand or contract depend on several industry characteristics. Sectors which are likely to expand are those that either: export a relatively large share of their output; obtain an exogenous increase in export prices as a result of WTO accession; are relatively unprotected initially compared to other sectors of the economy; or experience a significant reduction in the cost of their intermediate inputs, typically because they have a large share of intermediate inputs that come from sectors that produce additional varieties due to trade or FDI liberalization.

The manufacturing sectors that we estimate are likely to expand their output the most are ferrous metals, chemicals and non-ferrous metals. ${ }^{20}$ These sectors are among the sectors that we assume will gain an exogenous increase in the price of its exports upon WTO accession. They are also among those that export the highest share of their output — they all export over thirty percent of the value of their output on

${ }^{20}$ In the Saint Petersburg, Northwest, Far East and North regions, we estimate a more substantial expansion of the business services sectors than in other regions, since, as explained above, these regions already experience more foreign direct investment relative to the other regions of the economy. The expansion of business services in these regions attracts labor and capital away from other sectors of the region, which explains why output of nonferrous metals declines in the Northwest region (and slightly in the Saint Petersburg region). But non-ferrous metals is a rather small sector in those regions so it does not significantly detract from the economy-wide overall expansion of non-ferrous metals-which is equal to 61 billion rubles in 2001 rubles.

The estimated decline in the value of non-ferrous metals output in the Northwest and Saint Petersburg regions is 100 million rubles for the sum of the decline from the two regions. Since value-added is 308 billion rubles in Saint Petersburg and 152 billion in the Northwest region in 2001 rubles, this is only about two-tenths of one percent of the value added of the regions. Economy-wide, value-added of non-ferrous metals is 195 billion rubles in 2001, so these declines are only about one-half of one percent of the value-added of non-ferrous metals. 
a national basis. Export intensity is important because a reduction in tariffs generally depreciates the real exchange rate (see Table 13 for estimates). Since the real exchange rate depreciates, sectors that export intensively will gain an increase in the value of their exports in terms of rubles. ${ }^{21}$

Declining Manufacturing Sectors. The sectors that contract the most are the sectors that are the most protected prior to tariff reduction and which have a relatively small share of exports. Most notably this includes food, machinery and equipment and construction materials. All of these sectors do little exporting and are among the sectors with tariff rates above ten percent. Textiles and apparel, with the highest tariff in the economy, also declines, but less significantly. But the export and import intensities vary across regions, so results differ across regions.

Business Services Sectors. Russian business and labor interests in these sectors are not the same, and we discuss the impact on labor in these sectors first. Our central estimates, shown in tables 16 and 17, are that skilled and unskilled employment will expand in several business services sectors, most notably telecommunications, truck transportation and railway transportation services. The reason is that as a result of a reduction in the barriers to foreign direct investment in these sectors, we estimate that there will be an expansion in the number of multinational firms who locate in Russia to provide business services from within Russia, and a contraction in the number of purely Russian firms. But multinationals also demand Russian labor, even though they use Russian labor slightly less intensively than Russian firms. ${ }^{22}$ But as more service firms enter the market, the quality adjusted price of services falls, and

\footnotetext{
${ }^{21}$ Formally, there is no money in the model, so the value of exports increases in terms of the numeraire. The real exchange depreciates because the increased demand for imports accompanying the decline in tariffs induces an increase in the price of foreign exchange. In addition, the reduction in barriers to multinational investment in the services sector depreciates the real exchange rate. This is because multinationals use more foreign skilled labor, and they must pay in foreign exchange for the foreign skilled labor from domestic sales. The depreciation of the real exchange rate encourages exports and mutes the import expansion. The depreciated real exchange rate results in the export sectors having an increased incentive to export even if the tariffs in the export markets are unchanged. This is one of the primary reasons that international trade economists say that an import tariff is equivalent to a tax on exports. Given our view that Russia will neither give nor receive a free lunch from the rest of the world in the long run, we assume that there must be an increase in the value of exports to match the increase in the value of imports accompanying tariff reduction. The real exchange rate is the principal variable that induces the equilibrium between the change in imports and exports.

${ }^{22}$ As discussed above, we have employed estimates of the share of expatriate labor used by multinationals provided by Russian research institutes in the services sectors. In general the share is small, from about 3 to 15 percent, depending on the sector. We perform sensitivity analysis, using the high and low estimates provided by the research institutes.
} 
industries that use services expand their quantity demanded for business services. For telecommunications, truck transportation and railway transportation services, on balance, the increase in labor demand from the increase in the demand for business services exceeds the decline in labor demand from the substitution of multinational supply for Russian supply in the Russian market. Thus, we estimate that labor in these business services sectors will gain from an expansion in foreign direct investment and multinational provision of services in Russia.

These results are not uniform, however, as in maritime and financial services sectors we estimate a decline in employment. In these sectors the fact that multinationals use Russian labor less intensively dominates the impact of the greater use of business services.

Regarding capital, as a result of the removal of restrictions, we estimate there would be significant increase in foreign direct investment and an increase in multinational firms operating in Russia. Regarding Russian firms, we must be careful in interpreting what this means. As discussed above, we define joint ventures between Russian firms and multinationals as a multinational firm. An estimated decline in Russian firms does not mean their capital moved to other sectors or disappears. In many cases, it means the Russian firms have become joint venture partners with a multinational firm in the same sector. Multinationals will often look for Russian joint venture partners when they want to invest in Russia. Many Russian companies providing business services are likely to see this as a profitable opportunity and form joint ventures with multinationals. These Russian companies will become part of the expanding multinational share of the business services market. The Russian firms that become part of joint ventures with foreign investors will likely preserve or increase the value of their investments. Russian capital owners in business services who remain wholly independent of multinational firms, either because they avoid joint ventures or are not desired as joint venture partners, will likely see the value of their investments decline.

This suggests that domestic lobbying interests within a service sector are very diverse regarding FDI liberalization. We estimate that labor should find it in their interest to support FDI liberalization even if capital owners in the sector oppose it. But capital owners themselves may have diverse interests depending on their prospects for acquisition by multinationals. 


\section{Sensitivity Analysis}

\section{Sensitivity to Investment Potential of the Regions}

In our central scenario, results differ across regions due to a significant extent to the inherited FDI of the regions - the more existing FDI, the more the regions are capable of attracting new FDI for the same elasticities. In this scenario we augment the assessment of how regions may adapt and attract FDI based on the ranking of their investment potential. For investment potential ranking we use the rankings of Expert RA, which we explain in Appendix B. We use the investment potential rankings to adjust a parameter in our model (etaf) that reflects the responsiveness (elasticity) of foreign investment supply to an increase in the price of their product in the region. We assign higher values of etaf to regions with above average investment potential rankings and conversely for low investment potential rankings. We present these results in the first row of new results in table 19, where we also indicate how the elasticity etaf varies across regions based on the investment rankings.

The principal result is that the estimated gains for Moscow, St. Petersburg and Tumen increase and the estimated gains for Siberia, Northwest, North, Central and the Far East decline. Despite smaller estimated gains in this scenario, Far East and Northwest are still estimated to receive above average gains. The results suggest that the gains for a region could vary considerably depending on whether it succeeds in creating an atmosphere conducive to investment.

\section{Sensitivity to Results to a $50 \%$ Cut in the Barriers to Foreign Direct Investment}

We perform sensitivity analysis with respect to the extent of liberalization of barriers to foreign direct investment. In this scenario, we cut in the ad valorem tax equivalence of the barriers to FDI in the services sectors by 50 percent of the cut we executed in our central scenario. In this scenario, we allow for improved market access and a fifty percent cut in tariff barriers. We find that the gains to the economy are reduced to about 4.2 percent of consumption or 2.4 percent of GDP. St. Petersburg and the Northwest regions still are the regions that gain the most, but the rainking of gains among other regions changes slightly—reflecting different relative gains from FDI, versus tariff reduction or improved market access. 


\section{Piecemeal Sensitivity Analysis}

In table 19, we present the impact on welfare of varying the value of key parameters. In these scenarios, we retain the central value of all parameters except the parameter in question. In general, the gains to the economy (welfare gains) increase with an increase in elasticities, since higher elasticities imply that the economy is able to more easily shift to sectors or products that are cheaper after trade and FDI liberalization. ${ }^{23}$ There are two parameters in the table that have a strong impact on the results: the elasticity of substitution between value-added and business services (esubs) and the elasticity of multinational firm supply (etaf). A liberalization of the barriers to FDI will result in a reduction in the cost of business services, both from the direct effect of lowering the costs of doing business for multinational service providers and from the indirect effect that additional varieties of business services allow users to purchase a quality adjusted unit of services at less cost. When the elasticity of substitution between value-added and business services is high (esubs $=2$ in table 19), users have the greater potential to substitute the cheaper business services and this increases productivity. The elasticity of multinational and Russian firm supply (etaf, etad) is primarily dependent on the sector specific factor for each firm type (foreign or domestic). When etaf is high, a reduction in the barriers to foreign direct investment results in a larger expansion in the number of multinational firms supplying the Russian market, and hence more gains from additional varieties of business services. In addition, the share of the services market captured by multinationals has a strong effect, since a liberalization results in a larger number of new varieties introduced.

\section{Conclusions}

These results are consistent with the themes of empirical work on multilateral trade liberalization that suggest that a country will generally gain more from its own liberalization than it gains from improved access to the markets of its trading partners. Improved market access is a gain to Russia but is quantitatively less important than its own tariff and FDI liberalization in terms of increases in Russian

\footnotetext{
${ }^{23}$ An increase in the elasticity of substitution between varieties reduces the welfare gain. This is because when varieties are good substitutes, additional varieties are worth less to firms and consumers.
} 
welfare from WTO accession. In addition, we find that in the Russian context, liberalization of barriers to FDI are quantitatively more important than tariff liberalization. In part, this reflects the starting point of the analysis, in which we assess that Russia has done more to lower it tariffs on goods than it has to liberalize its barriers to FDI in services sectors. But it is also explained by the economic geography literature that suggests that access to a diverse set of service providers is crucial for growth.

Regional results in our central scenario differ mainly due to inherited FDI, where more existing FDI allows a region to more easily attract new FDI when barriers against FDI are relaxed. In our sensitivity analysis, we show that a better investment potential of a region will also lead to larger gains for a region. So creating a good investment climate can help a region gain more from WTO accession.

\section{References}

Brown, Drusilla and Robert Stern (2001), "Measurement and Modeling of the Economic Effects of Trade and Investment Barriers in Services,” Review of International Economics, 9(2): 262-286.

Caballero, R. and R. Lyons (1992), “The Case for External Economies,” in A. Cukierman, Z. Hercowitz and L. Leiderman, eds., Political Economy, Growth and Business Cycles, Cambridge, Massachusetts: MIT Press.

Chinitz, B. (1961), “Contrast in agglomeration: New York and Pittsburgh,” American Economic Review, Papers and Proceedings, 51:279-89.

Ciccone, A. and R. Hall (1996), "Productivity and the Density of Economic Activity,” American Economic Review, 86(1):54-70.

Dee, Philippa, Kevin Hanslow and Tien Phamduc (2003), "Measuring the Costs of Barriers to Trade in Services,” in Takatoshi Ito and Anne Krueger (eds.), Trade in Services in the Asia-Pacific Region, Chicago: University of Chicago Press.

Dixit, A. and J. Stiglitz (1977), “Monopolistic Competition and Optimum Product Diversity,” American Economic Review, 76(1):297-308.

Ethier, W.J. (1982), "National and International Returns to Scale in the Modern Theory of International Trade,” American Economic Review, 72(2):389-405.

Findlay, Christopher and Tony Warren (eds), Impediments to Trade in Services: Measurement and Policy Implications, (London: Routledge), 2000.

Fujita, Masahisa, Paul Krugman and Anthony J. Venables (1999), The Spatial Economy: Cities, Regions, and International Trade, Cambridge: MIT Press.

Harrison, Glenn, Thomas Rutherford and David Tarr (1997), “Quantifying the Uruguay Round,” Economic Journal. 
Holmes, T. (1995), “Localization of Industry and Vertical Disintegration,” Federal Reserve Bank of Minneapolis.

Hummels, D (1995), “Global Income Clustering and Trade in Intermediate Goods,” Graduate School of Business, University of Chicago.

Ivanova, Nadezhda (2005), "Estimates of Own and Cross-Price Elasticities of Disaggregated Imported and Domestic Goods in Russia, Graduate Institute of International Studies, Geneva. Available at http://siteresources.worldbank.org/INTRANETTRADE/Resources/Topics/Accession/elasticities_ NIvanova_sep2005_eng.pdf

Jacobs, J. (1969), The Economy of Cities, New York: Random House.

Jensen, Jesper, Thomas Rutherford and David Tarr (forthcoming), “The Impact of Liberalizing Barriers to Foreign Direct Investment in Services: The Case of Russian Accession to the World Trade Organization" Review of Development Economics.

Kimura, Fukunari, Mitsuyo Ando and Takamune Fujii (2004a), "Estimating the Ad Valorem Equivalent of Barriers to Foreign Direct Investment in the Telecommunications Services Sectors in Russia." Available at http://www.worldbank.org/trade/russia-wto.

Kimura, Fukunari, Mitsuyo Ando and Takamune Fujii (2004b), "Estimating the Ad Valorem Equivalent of Barriers to Foreign Direct Investment in the Maritime and Air Transportation Service Sectors in Russia.” Available at http://www.worldbank.org/trade/russia-wto.

Kimura, Fukunari, Mitsuyo Ando and Takamune Fujii (2004c), "Estimating the Ad Valorem Equivalent of Barriers to Foreign Direct Investment in Financial Services Sectors in Russia.” Available at http://www.worldbank.org/trade/russia-wto.

Markusen, James R. (1989), "Trade in Producer Services and in Other Specialized Intermediate Inputs," American Economic Review, 79:85-95.

Markusen, James R, Thomas Rutherford and David Tarr (2005), Trade and Direct Investment in Producer Services and the Domestic Market for Expertise,” Canadian Journal of Economics, Vol 38 (3), 758-777.

Marshall, J.N. (1988), Services and Uneven Development, London: Oxford University Press.

Matusz, Steven J, and David G. Tarr (2001), “Adjusting to Trade Policy Reform,” in A. Krueger (ed.), Economic Policy Reform, Chicago: University of Chicago Press.

Romer, Paul. (1994), “New Goods, Old Theory and the Welfare Costs of Trade Restrictions,” Journal of Development Economics," 43(1), February, 5-38.

Rossat (2002; 2003), Regions of Russia: Social and Economic Indicators, Moscow: Federal Service of State Statistics.

Rutherford, Thomas F. and David Tarr (2002), "Trade Liberalization and Endogenous Growth in a Small Open Economy," Journal of International Economics. 
Rutherford, Thomas F. (1999), "Applied General Equilibrium Modeling with MPSGE as a GAMS Subsystem: An Overview of the Modeling Framework and Syntax", Computational Economics.

Tarr, David, Oleksandr Shepotylo and Timour Koudoyarov (2006), "The Structure of import tariffs in Russia: 2001-2003,” in Trade Policy and WTO Accession for Development in Russia and the CIS: A Handbook, edited by David Tarr, in Russian, Moscow: Ves Mir. Available in English and Russian at www.worldbank.org/trade/russia-wto.

United Nations Conference on Trade and Development and World Bank (1994), Liberalizing Trade in Services: A Handbook, New York and Geneva: United Nations.

United Nations Conference on Trade and Development, Division on Transnational Corporations and Investment (1995 and 1996), World Investment Report 1995 and 1996, New York and Geneva: United Nations.

Vernon, R. (1960), Metropolis 1985, Cambridge: Harvard University Press. 
Table 1. List of Sectors

1. Sectors where foreign direct investment from new multinational services providers is possible

$\begin{array}{ll}\text { RLW } & \text { Railway transportation } \\ \text { TRK } & \text { Truck transportation } \\ \text { PIP } & \text { Pipelines transportation } \\ \text { MAR } & \text { Maritime transportation } \\ \text { AIR } & \text { Air transportation } \\ \text { TRO } & \text { Other transportation } \\ \text { TMS } & \text { Telecommunications } \\ \text { SCI } & \text { Science \& science servicing } \\ \text { FIN } & \text { Financial services }\end{array}$

2. Sectors where new foreign firms may provide new goods from abroad

$\begin{array}{ll}\text { FME } & \text { Ferrous metallurgy } \\ \text { NFM } & \text { Non-ferrous metallurgy } \\ \text { CHM } & \text { Chemical \& oil-chemical industry } \\ \text { MWO } & \text { Mechanical engineering \& metal-working } \\ \text { TPP } & \text { Timber \& woodworking \& pulp \& paper industry } \\ \text { CNM } & \text { Construction materials industry } \\ \text { FOO } & \text { Food industry } \\ \text { OTI } & \text { Other industries }\end{array}$

3. Competitive sectors subject to constant returns to scale

$\begin{array}{ll}\text { HEA } & \text { Public services, culture and arts } \\ \text { AGR } & \text { Agriculture \& forestry } \\ \text { COL } & \text { Coalmining } \\ \text { HOU } & \text { Housing and communal services } \\ \text { CON } & \text { Construction } \\ \text { ELE } & \text { Electric industry } \\ \text { GAS } & \text { Gas } \\ \text { CRU } & \text { Crude oil extraction } \\ \text { OIL } & \text { Oil refining and processing } \\ \text { OTH } & \text { Other goods-producing sectors } \\ \text { PST } & \text { Post } \\ \text { TRD } & \text { Wholesale and retail trade } \\ \text { CLI } & \text { Textiles and apparel }\end{array}$




\section{Table 2. List of Russian Regional Markets and Oblasts}

Russian regional "markets" (markets are aggregates of oblasts defined below)

$\begin{array}{ll}\text { msc } & \text { Moscow } \\ \text { stp } & \text { Saint-Petersburg } \\ \text { tmn } & \text { Tumenskaya } \\ \text { vgd } & \text { Northwest } \\ \text { nor } & \text { North } \\ \text { cen } & \text { Central } \\ \text { sou } & \text { South } \\ \text { url } & \text { Urals } \\ \text { sib } & \text { Siberia } \\ \text { far } & \text { Far East }\end{array}$

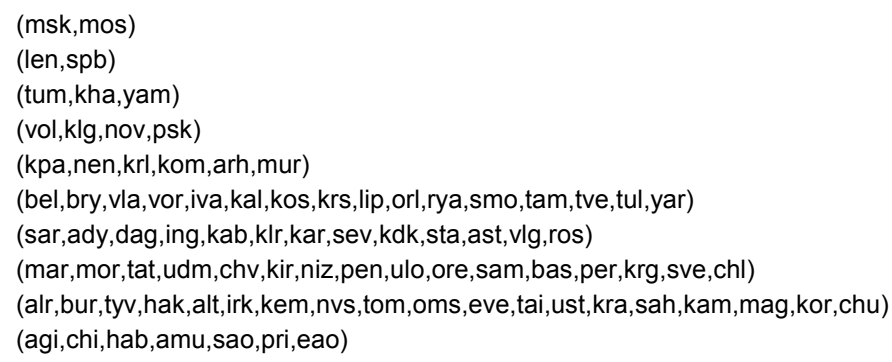

Oblasts (plus Republics, Territories, Federal Cities, Autonomous Regions, Autonomous Districts)

\begin{tabular}{|c|c|c|c|}
\hline 1. ady & Adygeya, The Republic of & 46. mar & Mari El, The Republic of \\
\hline 2. agi & Aginsky Buryatsky Autonomous District & 47. mor & Mordovia, The Republic of \\
\hline 3. alt & Altaisky krai & 48. msk & Moscow city \\
\hline 4. alr & Altay Republic & 49. mos & Moskovskaya \\
\hline 5. amu & Amurskaya & 50. mur & Murmanskaya \\
\hline 6. arh & Arkhangelskaya & 51. nen & Nenetsky Autonomous District \\
\hline 7. ast & Astrakhanskaya & 52. niz & Nizhegorodskaya \\
\hline 8. bas & Bashkortostan, The Republic of & 53. sev & North Osetia, The Republic of \\
\hline 9. bel & Belgorodskaya & 54. nov & Novgorodskaya \\
\hline 10. bry & Bryanskaya & 55. nvs & Novosibirskaya \\
\hline 11. bur & Buryatia, The Republic of & 56. oms & Omskaya \\
\hline 12. $\mathrm{chr}$ & Chechnya (sou), The Republic of */ & 57. ore & Orenburgskaya \\
\hline 13. chl & Chelyabinskaya & 58. orl & Orlovskaya \\
\hline 14. chi & Chitinskaya & 59. pen & Penzenskaya \\
\hline 15. chu & Chukotsky Autonomous District & 60. per & Permskaya \\
\hline 16. chv & Chuvashia, The Republic of & 61. pri & Primorsky krai \\
\hline 17. dag & Dagestan, The Republic of & 62. psk & Pskovskaya \\
\hline 18. eve & Evenkiysky Autonomous District & 63. ros & Rostovskaya \\
\hline 19. ing & Ingushetia, The Republic of & 64. rya & Ryazanskaya \\
\hline 20. irk & Irkutskaya & 65. spb & Saint Petersburg City \\
\hline 21. iva & Ivanovskaya & 66. sah & Sakha, The Republic of \\
\hline 22. eao & Jewish Autonomous Region & 67. sao & Sakhalinskaya \\
\hline 23. kab & Kabardino Balkaria, The Republic of & 68. sam & Samarskaya \\
\hline 24. $\mathrm{klg}$ & Kaliningradskaya & 69. sar & Saratovskaya \\
\hline 25. kal & Kaluzhskaya & 70. smo & Smolenskaya \\
\hline 26. klr & Kalymykia, The Republic of & 71. sta & Stavropolsky krai \\
\hline 27. kam & Kamchatskaya & 72. sve & Sverdlovskaya \\
\hline $\begin{array}{l}\text { 28. kar } \\
\text { 29. krl }\end{array}$ & $\begin{array}{l}\text { Karachaevo Cherkessia, The Republic of } \\
\text { Karelia, The Republic of }\end{array}$ & 73. tai & $\begin{array}{l}\text { Taimyrsky (Dolgano-Nenetsky) Autonomous } \\
\text { District }\end{array}$ \\
\hline 30. kem & Kemerovskaya & 74. tam & Tambovskaya \\
\hline 31. hab & Khabarovsky krai & 75. tat & Tatarstan, The Republic of \\
\hline 32. hak & Khakasia, The Republic of & 76. tom & Tomskaya \\
\hline 33. kha & Khanty-Mansiysky Autonomous District & 77. tul & Tulskaya \\
\hline 34. kir & Kirovskaya & 78. tum & Tumenskaya \\
\hline 35. kom & Komi, The Republic of & 79. tve & Tverskaya \\
\hline 36. kpa & Komi-Permyatsky Autonomous District & 80. tyv & Tyva, The Republic of \\
\hline 37. kor & Koryaksky Autonomous District & 81. udm & Udmurtia, The Republic of \\
\hline 38. kos & Kostromskaya & 82. ulo & Ulyanovskaya \\
\hline 39. kdk & Krasnodarsky krai & 83. ust & Ust-ordynsky Buryatsky Autonomous District \\
\hline 40. kra & Krasnoyarsky krai & 84. vla & Vladimirskaya \\
\hline 41. $\mathrm{krg}$ & Kurganskaya & 85. vlg & Volgogradskaya \\
\hline 42. krs & Kurskaya & 86. vol & Vologodskaya \\
\hline 43. len & Leningradskaya & 87. vor & Voronezhskaya \\
\hline 44. lip & Lipetskaya & 88. yam & Yamalo-Nenetsky Autonomous District \\
\hline 45. mag & Maganskaya & 89. yar & Yaroslavskaya \\
\hline
\end{tabular}

${ }^{\prime}$ No data. 
Table 3. Value Added in $\mathbf{2 0 0 0}$ by Russian Regional Market and by Sector

(in billions of 2001 rubles) ${ }^{a /}$

\begin{tabular}{|c|c|c|c|c|c|c|c|c|c|c|c|}
\hline Sector ${ }^{b /}$ & Central & Far East & North & Siberia & South & Urals & Moscow & $\begin{array}{r}\text { St. } \\
\text { Petersb. }\end{array}$ & Tumen & $\begin{array}{r}\begin{array}{r}\text { North- } \\
\text { west }\end{array} \\
\end{array}$ & $\begin{array}{r}\text { Sector } \\
\text { total }\end{array}$ \\
\hline MAR & 4.7 & 1.3 & 1.4 & 7.2 & 4.1 & 14.7 & 4.0 & 1.7 & 6.9 & 1.0 & 47.1 \\
\hline AGR & 110.2 & 17.5 & 7.4 & 84.8 & 125.2 & 155.3 & 15.2 & 11.8 & 8.2 & 15.1 & 550.7 \\
\hline AIR & 3.6 & 1.3 & 1.0 & 5.3 & 4.5 & 10.0 & 14.9 & 1.6 & 2.5 & 0.6 & 45.2 \\
\hline $\mathrm{CHM}$ & 13.9 & 0.3 & 1.6 & 10.6 & 9.3 & 35.6 & 7.7 & 2.0 & 0.1 & 4.2 & 85.4 \\
\hline CNM & 10.3 & 1.1 & 0.7 & 4.6 & 6.7 & 12.2 & 8.8 & 2.4 & 0.8 & 0.7 & 48.2 \\
\hline COL & 0.1 & 5.2 & 3.2 & 32.6 & 1.7 & 1.2 & & & & & 43.9 \\
\hline CON & 76.4 & 7.1 & 6.1 & 54.7 & 105.2 & 151.6 & 138.6 & 29.7 & 24.1 & 11.4 & 605.0 \\
\hline CRU & & 4.5 & 16.9 & 9.9 & 37.7 & 97.5 & & & 282.9 & 1.0 & 450.3 \\
\hline ELE & 26.7 & 7.8 & 7.1 & 34.7 & 22.9 & 62.9 & 42.9 & 10.5 & 19.1 & 5.8 & 240.4 \\
\hline FIN & 43.5 & 16.4 & 14.3 & 60.7 & 44.0 & 106.8 & 115.7 & 20.8 & 47.0 & 9.0 & 478.0 \\
\hline FME & 19.0 & 0.5 & 1.6 & 9.0 & 3.9 & 33.8 & 2.3 & 1.1 & & 11.3 & 82.5 \\
\hline FOO & 24.9 & 9.2 & 3.7 & 17.4 & 24.0 & 28.1 & 33.9 & 17.7 & 0.5 & 4.7 & 164.2 \\
\hline GAS & & 0.2 & 0.4 & 0.5 & 1.5 & 2.8 & & & 52.2 & 0.0 & 57.5 \\
\hline HEA & 42.3 & 17.5 & 14.6 & 58.8 & 45.0 & 100.6 & 126.3 & 21.8 & 40.6 & 8.9 & 476.4 \\
\hline $\mathrm{HOU}$ & 22.1 & 8.8 & 6.7 & 29.1 & 24.8 & 50.9 & 68.0 & 11.2 & 13.7 & 4.6 & 239.8 \\
\hline MWO & 38.7 & 11.2 & 2.6 & 19.4 & 18.0 & 101.8 & 45.4 & 18.9 & 3.0 & 3.6 & 262.7 \\
\hline NFM & 2.5 & 8.1 & 9.3 & 113.2 & 4.8 & 46.0 & 7.1 & 4.4 & & 0.2 & 195.5 \\
\hline OIL & 12.2 & 4.7 & 1.5 & 17.4 & 10.1 & 39.2 & 4.4 & 7.2 & 3.9 & & 100.6 \\
\hline OTH & 7.7 & 2.0 & 2.2 & 8.8 & 4.9 & 18.4 & 6.3 & 3.3 & 7.4 & 1.9 & 62.8 \\
\hline OTI & 13.6 & 0.6 & 0.7 & 2.5 & 4.0 & 9.2 & 9.9 & 2.6 & 0.1 & 0.9 & 44.0 \\
\hline PIP & 1.5 & 0.5 & 0.5 & 2.0 & 1.7 & 5.4 & 1.2 & 0.7 & 5.2 & 0.2 & 18.7 \\
\hline PST & 2.7 & 1.0 & 0.8 & 3.5 & 2.9 & 6.3 & 6.8 & 1.3 & 2.8 & 0.6 & 28.7 \\
\hline RLW & 23.5 & 6.9 & 6.3 & 30.2 & 20.5 & 53.8 & 34.5 & 9.4 & 16.1 & 6.2 & 207.3 \\
\hline $\mathrm{SCl}$ & 8.8 & 3.2 & 2.4 & 10.4 & 7.8 & 22.6 & 16.5 & 4.1 & 9.8 & 1.5 & 87.0 \\
\hline TMS & 7.6 & 2.8 & 2.2 & 10.1 & 8.3 & 18.7 & 21.1 & 3.6 & 7.4 & 1.5 & 83.3 \\
\hline TPP & 6.8 & 4.4 & 15.1 & 13.1 & 2.6 & 13.0 & 6.8 & 7.3 & 0.6 & 4.2 & 73.9 \\
\hline TRD & 205.4 & 78.2 & 67.0 & 300.6 & 223.3 & 535.3 & 456.6 & 101.6 & 386.8 & 48.2 & $2,402.9$ \\
\hline TRK & 10.2 & 3.5 & 3.1 & 13.6 & 11.3 & 24.6 & 23.0 & 4.7 & 12.9 & 2.2 & 109.2 \\
\hline TRO & 4.5 & 1.5 & 1.3 & 5.7 & 5.1 & 11.2 & 10.7 & 2.0 & 5.7 & 0.9 & 48.7 \\
\hline CLI & 3.8 & 1.6 & 1.2 & 5.0 & 4.4 & 8.6 & 12.9 & 2.0 & 1.9 & 0.8 & 42.3 \\
\hline $\begin{array}{l}\text { Market } \\
\text { total }\end{array}$ & 747.2 & 228.8 & 202.7 & 975.2 & 790.0 & $1,778.0$ & $1,241.5$ & 305.6 & 962.3 & 151.1 & $7,382.4$ \\
\hline
\end{tabular}

a/ Value added defined here does not include taxes.

b/ Sector codes are in Table 1, oblasts in the markets are listed in Table 2.

Source: Regions of Russia, Roskomstat, and authors' calculations. 
Table 4. Value-Added by Sector as a percent of the Value-Added of the Regional Market

\begin{tabular}{|c|c|c|c|c|c|c|c|c|c|c|}
\hline Sector & Central & Far East & North & Siberia & South & Urals & Moscow & $\begin{array}{r}\text { St. } \\
\text { Petersb. }\end{array}$ & Tumen & $\begin{array}{r}\text { North- } \\
\text { west }\end{array}$ \\
\hline MAR & 0.6 & 0.6 & 0.7 & 0.7 & 0.5 & 0.8 & 0.3 & 0.6 & 0.7 & 0.6 \\
\hline AGR & 14.8 & 7.6 & 3.7 & 8.7 & 15.8 & 8.7 & 1.2 & 3.9 & 0.9 & 10.0 \\
\hline AIR & 0.5 & 0.6 & 0.5 & 0.5 & 0.6 & 0.6 & 1.2 & 0.5 & 0.3 & 0.4 \\
\hline $\mathrm{CHM}$ & 1.9 & 0.1 & 0.8 & 1.1 & 1.2 & 2.0 & 0.6 & 0.7 & 0.0 & 2.8 \\
\hline CNM & 1.4 & 0.5 & 0.4 & 0.5 & 0.8 & 0.7 & 0.7 & 0.8 & 0.1 & 0.4 \\
\hline COL & 0.0 & 2.3 & 1.6 & 3.3 & 0.2 & 0.1 & & & & \\
\hline CON & 10.2 & 3.1 & 3.0 & 5.6 & 13.3 & 8.5 & 11.2 & 9.7 & 2.5 & 7.6 \\
\hline CRU & & 1.9 & 8.3 & 1.0 & 4.8 & 5.5 & & & 29.4 & 0.7 \\
\hline ELE & 3.6 & 3.4 & 3.5 & 3.6 & 2.9 & 3.5 & 3.5 & 3.5 & 2.0 & 3.9 \\
\hline FIN & 5.8 & 7.2 & 7.0 & 6.2 & 5.6 & 6.0 & 9.3 & 6.8 & 4.9 & 5.9 \\
\hline FME & 2.5 & 0.2 & 0.8 & 0.9 & 0.5 & 1.9 & 0.2 & 0.4 & & 7.5 \\
\hline FOO & 3.3 & 4.0 & 1.8 & 1.8 & 3.0 & 1.6 & 2.7 & 5.8 & 0.1 & 3.1 \\
\hline GAS & & 0.1 & 0.2 & 0.0 & 0.2 & 0.2 & & & 5.4 & 0.0 \\
\hline HEA & 5.7 & 7.6 & 7.2 & 6.0 & 5.7 & 5.7 & 10.2 & 7.1 & 4.2 & 5.9 \\
\hline $\mathrm{HOU}$ & 3.0 & 3.8 & 3.3 & 3.0 & 3.1 & 2.9 & 5.5 & 3.7 & 1.4 & 3.0 \\
\hline MWO & 5.2 & 4.9 & 1.3 & 2.0 & 2.3 & 5.7 & 3.7 & 6.2 & 0.3 & 2.4 \\
\hline NFM & 0.3 & 3.5 & 4.6 & 11.6 & 0.6 & 2.6 & 0.6 & 1.4 & & 0.1 \\
\hline OIL & 1.6 & 2.1 & 0.8 & 1.8 & 1.3 & 2.2 & 0.4 & 2.4 & 0.4 & \\
\hline OTH & 1.0 & 0.9 & 1.1 & 0.9 & 0.6 & 1.0 & 0.5 & 1.1 & 0.8 & 1.2 \\
\hline OTI & 1.8 & 0.2 & 0.3 & 0.3 & 0.5 & 0.5 & 0.8 & 0.8 & 0.0 & 0.6 \\
\hline PIP & 0.2 & 0.2 & 0.2 & 0.2 & 0.2 & 0.3 & 0.1 & 0.2 & 0.5 & 0.1 \\
\hline PST & 0.4 & 0.4 & 0.4 & 0.4 & 0.4 & 0.4 & 0.6 & 0.4 & 0.3 & 0.4 \\
\hline RLW & 3.1 & 3.0 & 3.1 & 3.1 & 2.6 & 3.0 & 2.8 & 3.1 & 1.7 & 4.1 \\
\hline $\mathrm{SCl}$ & 1.2 & 1.4 & 1.2 & 1.1 & 1.0 & 1.3 & 1.3 & 1.4 & 1.0 & 1.0 \\
\hline TMS & 1.0 & 1.2 & 1.1 & 1.0 & 1.0 & 1.1 & 1.7 & 1.2 & 0.8 & 1.0 \\
\hline TPP & 0.9 & 1.9 & 7.5 & 1.3 & 0.3 & 0.7 & 0.5 & 2.4 & 0.1 & 2.8 \\
\hline TRD & 27.5 & 34.2 & 33.0 & 30.8 & 28.3 & 30.1 & 36.8 & 33.3 & 40.2 & 31.9 \\
\hline TRK & 1.4 & 1.5 & 1.5 & 1.4 & 1.4 & 1.4 & 1.9 & 1.5 & 1.3 & 1.5 \\
\hline TRO & 0.6 & 0.7 & 0.7 & 0.6 & 0.6 & 0.6 & 0.9 & 0.7 & 0.6 & 0.6 \\
\hline CLI & 0.5 & 0.7 & 0.6 & 0.5 & 0.6 & 0.5 & 1.0 & 0.7 & 0.2 & 0.5 \\
\hline Total & 100.0 & 100.0 & 100.0 & 100.0 & 100.0 & 100.0 & 100.0 & 100.0 & 100.0 & 100.0 \\
\hline
\end{tabular}

See Table 1 for sector codes.

Source: Regions of Russia, Roskomstat. 
Table 5. Share of Sector Value-Added by Regional Market of Russia

(in percent)

\begin{tabular}{|c|c|c|c|c|c|c|c|c|c|c|c|}
\hline Good & Central & Far East & North & Siberia & South & Urals & Moscow & $\begin{array}{r}\text { St. } \\
\text { Petersb. }\end{array}$ & Tumen & $\begin{array}{r}\text { North- } \\
\text { west }\end{array}$ & $\begin{array}{r}\text { Sector } \\
\text { Total }\end{array}$ \\
\hline MAR & 10.0 & 2.8 & 2.9 & 15.2 & 8.8 & 31.3 & 8.5 & 3.7 & 14.7 & 2.0 & 100.0 \\
\hline AGR & 20.0 & 3.2 & 1.3 & 15.4 & 22.7 & 28.2 & 2.8 & 2.1 & 1.5 & 2.7 & 100.0 \\
\hline AIR & 7.9 & 2.8 & 2.1 & 11.6 & 10.0 & 22.1 & 32.9 & 3.6 & 5.5 & 1.4 & 100.0 \\
\hline $\mathrm{CHM}$ & 16.3 & 0.4 & 1.8 & 12.4 & 10.9 & 41.6 & 9.1 & 2.4 & 0.1 & 4.9 & 100.0 \\
\hline CNM & 21.3 & 2.3 & 1.5 & 9.6 & 13.9 & 25.2 & 18.2 & 4.9 & 1.6 & 1.4 & 100.0 \\
\hline $\mathrm{COL}$ & 0.3 & 11.8 & 7.3 & 74.2 & 3.8 & 2.7 & & & & & 100.0 \\
\hline CON & 12.6 & 1.2 & 1.0 & 9.0 & 17.4 & 25.1 & 22.9 & 4.9 & 4.0 & 1.9 & 100.0 \\
\hline CRU & & 1.0 & 3.7 & 2.2 & 8.4 & 21.7 & & & 62.8 & 0.2 & 100.0 \\
\hline ELE & 11.1 & 3.2 & 2.9 & 14.4 & 9.5 & 26.2 & 17.9 & 4.4 & 7.9 & 2.4 & 100.0 \\
\hline FIN & 9.1 & 3.4 & 3.0 & 12.7 & 9.2 & 22.3 & 24.2 & 4.4 & 9.8 & 1.9 & 100.0 \\
\hline FME & 23.0 & 0.6 & 1.9 & 10.9 & 4.8 & 40.9 & 2.8 & 1.4 & & 13.7 & 100.0 \\
\hline FOO & 15.2 & 5.6 & 2.2 & 10.6 & 14.6 & 17.1 & 20.6 & 10.8 & 0.3 & 2.8 & 100.0 \\
\hline GAS & & 0.3 & 0.7 & 0.8 & 2.5 & 4.8 & & & 90.8 & 0.0 & 100.0 \\
\hline HEA & 8.9 & 3.7 & 3.1 & 12.3 & 9.4 & 21.1 & 26.5 & 4.6 & 8.5 & 1.9 & 100.0 \\
\hline $\mathrm{HOU}$ & 9.2 & 3.7 & 2.8 & 12.1 & 10.3 & 21.2 & 28.4 & 4.7 & 5.7 & 1.9 & 100.0 \\
\hline MWO & 14.7 & 4.3 & 1.0 & 7.4 & 6.8 & 38.8 & 17.3 & 7.2 & 1.1 & 1.4 & 100.0 \\
\hline NFM & 1.3 & 4.1 & 4.7 & 57.9 & 2.5 & 23.6 & 3.6 & 2.2 & & 0.1 & 100.0 \\
\hline OIL & 12.1 & 4.7 & 1.5 & 17.3 & 10.0 & 38.9 & 4.4 & 7.2 & 3.9 & & 100.0 \\
\hline OTH & 12.3 & 3.2 & 3.6 & 14.0 & 7.8 & 29.3 & 10.0 & 5.2 & 11.7 & 3.0 & 100.0 \\
\hline OTI & 30.8 & 1.3 & 1.6 & 5.7 & 9.1 & 20.9 & 22.5 & 5.8 & 0.2 & 2.1 & 100.0 \\
\hline PIP & 7.8 & 2.7 & 2.5 & 10.5 & 8.9 & 28.9 & 6.4 & 3.6 & 27.7 & 1.0 & 100.0 \\
\hline PST & 9.3 & 3.5 & 2.8 & 12.2 & 10.1 & 22.0 & 23.9 & 4.5 & 9.9 & 1.9 & 100.0 \\
\hline RLW & 11.3 & 3.3 & 3.0 & 14.6 & 9.9 & 25.9 & 16.6 & 4.5 & 7.8 & 3.0 & 100.0 \\
\hline $\mathrm{SCl}$ & 10.1 & 3.6 & 2.8 & 11.9 & 8.9 & 26.0 & 18.9 & 4.7 & 11.3 & 1.7 & 100.0 \\
\hline TMS & 9.1 & 3.3 & 2.7 & 12.1 & 9.9 & 22.4 & 25.3 & 4.3 & 8.9 & 1.8 & 100.0 \\
\hline TPP & 9.3 & 5.9 & 20.5 & 17.8 & 3.5 & 17.6 & 9.2 & 9.8 & 0.8 & 5.7 & 100.0 \\
\hline TRD & 8.5 & 3.3 & 2.8 & 12.5 & 9.3 & 22.3 & 19.0 & 4.2 & 16.1 & 2.0 & 100.0 \\
\hline TRK & 9.3 & 3.2 & 2.8 & 12.5 & 10.4 & 22.6 & 21.1 & 4.3 & 11.8 & 2.0 & 100.0 \\
\hline TRO & 9.2 & 3.1 & 2.7 & 11.7 & 10.5 & 23.0 & 21.9 & 4.2 & 11.8 & 1.9 & 100.0 \\
\hline CLI & 9.0 & 3.7 & 2.8 & 11.7 & 10.5 & 20.4 & 30.6 & 4.7 & 4.6 & 1.9 & 100.0 \\
\hline Total & 329.2 & 99.4 & 96.2 & 453.3 & 284.4 & 734.1 & 465.5 & 128.4 & 340.9 & 68.7 & 3000.0 \\
\hline
\end{tabular}

Source: Regions of Russia and authors calculations. 
Table 6: Exports by Product and by Regional Market (in billions of 2001 rubles)

\begin{tabular}{|c|c|c|c|c|c|c|c|c|c|c|}
\hline Good & Central & Far East & North & Siberia & South & Urals & Moscow & $\begin{array}{r}\text { St. } \\
\text { Petersb. }\end{array}$ & Tumen & $\begin{array}{r}\text { North- } \\
\text { west } \\
\end{array}$ \\
\hline MAR & 4.9 & 1.7 & 1.7 & 7.1 & 4.5 & 13.7 & 4.3 & 2.2 & 6.9 & 1.2 \\
\hline AGR & 3.1 & 0.5 & 0.2 & 2.4 & 3.5 & 4.4 & 0.4 & 0.3 & 0.2 & 0.4 \\
\hline AIR & 5.6 & 2.4 & 1.8 & 7.6 & 6.8 & 13.2 & 18.9 & 3.0 & 4.4 & 1.2 \\
\hline $\mathrm{CHM}$ & 27.5 & 0.5 & 2.0 & 33.2 & 18.2 & 92.0 & 13.7 & 5.0 & 0.3 & 15.2 \\
\hline CNM & 1.8 & 0.2 & 0.1 & 1.7 & 1.2 & 3.4 & 1.6 & 0.6 & 0.2 & 0.2 \\
\hline COL & 0.1 & 4.2 & 2.6 & 26.4 & 1.3 & 0.9 & & & & \\
\hline CON & 4.0 & 0.4 & 0.3 & 2.9 & 5.6 & 8.0 & 7.3 & 1.6 & 1.3 & 0.6 \\
\hline CRU & & 7.1 & 27.0 & 15.8 & 60.3 & 156.1 & & & 452.8 & 1.6 \\
\hline ELE & 1.1 & 0.3 & 0.3 & 1.4 & 1.0 & 2.6 & 1.8 & 0.4 & 0.8 & 0.2 \\
\hline FIN & 0.7 & 0.3 & 0.2 & 0.9 & 0.7 & 1.6 & 1.8 & 0.3 & 0.7 & 0.1 \\
\hline FME & 50.5 & 1.1 & 3.7 & 22.4 & 11.1 & 83.8 & 7.1 & 4.8 & & 28.3 \\
\hline FOO & 8.7 & 9.7 & 2.5 & 12.6 & 23.1 & 10.1 & 27.0 & 9.2 & 0.1 & 3.6 \\
\hline GAS & & 1.4 & 3.1 & 3.6 & 11.5 & 21.8 & & & 410.7 & 0.0 \\
\hline HEA & 0.3 & 0.1 & 0.1 & 0.4 & 0.3 & 0.6 & 0.8 & 0.1 & 0.2 & 0.1 \\
\hline $\mathrm{HOU}$ & 0.3 & 0.1 & 0.1 & 0.4 & 0.3 & 0.6 & 0.8 & 0.1 & 0.2 & 0.1 \\
\hline MWO & 22.8 & 14.2 & 1.9 & 43.0 & 23.3 & 97.0 & 95.5 & 30.4 & 1.9 & 5.0 \\
\hline NFM & 4.6 & 15.1 & 18.4 & 203.1 & 11.1 & 101.6 & 17.2 & 11.3 & & 0.6 \\
\hline OIL & 35.5 & 13.7 & 4.5 & 50.9 & 29.5 & 114.4 & 12.8 & 21.1 & 11.5 & \\
\hline OTH & 1.7 & 0.4 & 0.5 & 1.9 & 1.1 & 4.0 & 1.4 & 0.7 & 1.6 & 0.4 \\
\hline OTI & 7.2 & 0.3 & 0.4 & 1.3 & 2.1 & 4.9 & 5.3 & 1.4 & 0.0 & 0.5 \\
\hline PST & 0.3 & 0.1 & 0.1 & 0.5 & 0.4 & 0.8 & 0.9 & 0.2 & 0.4 & 0.1 \\
\hline RLW & 0.9 & 0.3 & 0.2 & 1.1 & 0.8 & 2.0 & 1.3 & 0.3 & 0.6 & 0.2 \\
\hline $\mathrm{SCl}$ & 0.6 & 0.2 & 0.2 & 0.7 & 0.5 & 1.6 & 1.1 & 0.3 & 0.7 & 0.1 \\
\hline TMS & 0.9 & 0.3 & 0.3 & 1.2 & 1.0 & 2.1 & 2.4 & 0.4 & 0.9 & 0.2 \\
\hline TPP & 3.1 & 17.1 & 29.2 & 35.1 & 1.7 & 13.3 & 2.1 & 12.7 & 0.4 & 8.1 \\
\hline TRD & 2.0 & 0.8 & 0.7 & 3.0 & 2.2 & 5.3 & 4.5 & 1.0 & 3.9 & 0.5 \\
\hline TRK & 0.4 & 0.1 & 0.1 & 0.5 & 0.4 & 0.9 & 0.9 & 0.2 & 0.5 & 0.1 \\
\hline TRO & 0.5 & 0.2 & 0.2 & 0.7 & 0.6 & 1.3 & 1.2 & 0.2 & 0.7 & 0.1 \\
\hline CLI & 2.6 & 1.1 & 0.8 & 3.4 & 3.1 & 6.0 & 9.0 & 1.4 & 1.3 & 0.5 \\
\hline
\end{tabular}

See Tables 1 and 2 for sector and region definitions.

Source: Roskomstat unpublished surveys and authors' calculations. 
Table 7. Sector Exports as a Percent of Total Exports of the Regional Market

\begin{tabular}{|c|c|c|c|c|c|c|c|c|c|c|}
\hline Good & Central & Far East & North & Siberia & South & Urals & Moscow & $\begin{array}{r}\text { St. } \\
\text { Petersb. }\end{array}$ & Tumen & $\begin{array}{r}\text { North- } \\
\text { west }\end{array}$ \\
\hline MAR & 3 & 2 & 2 & 1 & 2 & 2 & 2 & 2 & 1 & 2 \\
\hline AGR & 2 & 1 & 0 & 0 & 2 & 1 & 0 & 0 & 0 & 1 \\
\hline AIR & 3 & 3 & 2 & 2 & 3 & 2 & 8 & 3 & 0 & 2 \\
\hline $\mathrm{CHM}$ & 14 & 1 & 2 & 7 & 8 & 12 & 6 & 5 & 0 & 22 \\
\hline CNM & 1 & 0 & 0 & 0 & 1 & 0 & 1 & 1 & 0 & 0 \\
\hline COL & 0 & 4 & 3 & 5 & 1 & 0 & & & & \\
\hline CON & 2 & 0 & 0 & 1 & 2 & 1 & 3 & 1 & 0 & 1 \\
\hline CRU & & 8 & 26 & 3 & 27 & 20 & & & 50 & 2 \\
\hline ELE & 1 & 0 & 0 & 0 & 0 & 0 & 1 & 0 & 0 & 0 \\
\hline FIN & 0 & 0 & 0 & 0 & 0 & 0 & 1 & 0 & 0 & 0 \\
\hline FME & 26 & 1 & 4 & 5 & 5 & 11 & 3 & 4 & & 41 \\
\hline FOO & 5 & 10 & 2 & 3 & 10 & 1 & 11 & 8 & 0 & 5 \\
\hline GAS & & 2 & 3 & 1 & 5 & 3 & & & 45 & 0 \\
\hline HEA & 0 & 0 & 0 & 0 & 0 & 0 & 0 & 0 & 0 & 0 \\
\hline $\mathrm{HOU}$ & 0 & 0 & 0 & 0 & 0 & 0 & 0 & 0 & 0 & 0 \\
\hline MWO & 12 & 15 & 2 & 9 & 10 & 13 & 40 & 28 & 0 & 7 \\
\hline NFM & 2 & 16 & 18 & 42 & 5 & 13 & 7 & 10 & & 1 \\
\hline OIL & 19 & 15 & 4 & 10 & 13 & 15 & 5 & 19 & 1 & \\
\hline OTH & 1 & 0 & 0 & 0 & 0 & 1 & 1 & 1 & 0 & 1 \\
\hline OTI & 4 & 0 & 0 & 0 & 1 & 1 & 2 & 1 & 0 & 1 \\
\hline PST & 0 & 0 & 0 & 0 & 0 & 0 & 0 & 0 & 0 & 0 \\
\hline RLW & 0 & 0 & 0 & 0 & 0 & 0 & 1 & 0 & 0 & 0 \\
\hline $\mathrm{SCl}$ & 0 & 0 & 0 & 0 & 0 & 0 & 0 & 0 & 0 & 0 \\
\hline TMS & 0 & 0 & 0 & 0 & 0 & 0 & 1 & 0 & 0 & 0 \\
\hline TPP & 2 & 18 & 28 & 7 & 1 & 2 & 1 & 12 & 0 & 12 \\
\hline TRD & 1 & 1 & 1 & 1 & 1 & 1 & 2 & 1 & 0 & 1 \\
\hline TRK & 0 & 0 & 0 & 0 & 0 & 0 & 0 & 0 & 0 & 0 \\
\hline TRO & 0 & 0 & 0 & 0 & 0 & 0 & 1 & 0 & 0 & 0 \\
\hline CLI & 1 & 1 & 1 & 1 & 1 & 1 & 4 & 1 & 0 & 1 \\
\hline Total & 100 & 100 & 100 & 100 & 100 & 100 & 100 & 100 & 100 & 100 \\
\hline
\end{tabular}

See Tables 1 and 2 for sector and region definitions.

Source: Roskomstat unpublished surveys and authors' calculations. 
Table 8. Sector Export Intensities by Regional Market: Exports of the Sector as a Percent of Production of the Sector (in percent)

\begin{tabular}{|c|c|c|c|c|c|c|c|c|c|c|}
\hline Good & Central & Far East & North & Siberia & South & Urals & Moscow & $\begin{array}{r}\text { St. } \\
\text { Petersb. }\end{array}$ & Tumen & $\begin{array}{r}\text { North- } \\
\text { west }\end{array}$ \\
\hline MAR & 53 & 57 & 57 & 51 & 53 & 50 & 54 & 57 & 51 & 57 \\
\hline AGR & 1 & 1 & 1 & 1 & 1 & 1 & 1 & 1 & 1 & 1 \\
\hline AIR & 46 & 48 & 48 & 44 & 45 & 43 & 43 & 48 & 47 & 48 \\
\hline $\mathrm{CHM}$ & 27 & 21 & 17 & 48 & 27 & 37 & 24 & 35 & 40 & 57 \\
\hline CNM & 3 & 3 & 3 & 6 & 3 & 5 & 3 & 4 & 4 & 7 \\
\hline COL & 23 & 23 & 23 & 23 & 23 & 23 & & & & \\
\hline CON & 3 & 3 & 3 & 3 & 3 & 3 & 3 & 3 & 3 & 3 \\
\hline CRU & & 56 & 56 & 56 & 56 & 56 & & & 56 & 56 \\
\hline ELE & 2 & 2 & 2 & 2 & 2 & 2 & 2 & 2 & 2 & 2 \\
\hline FIN & 1 & 1 & 1 & 1 & 1 & 1 & 1 & 1 & 1 & 1 \\
\hline FME & 40 & 35 & 34 & 37 & 43 & 37 & 48 & 75 & & 37 \\
\hline FOO & 4 & 12 & 8 & 8 & 11 & 4 & 9 & 6 & 3 & 9 \\
\hline GAS & & 27 & 27 & 27 & 27 & 27 & & & 27 & 27 \\
\hline HEA & 0 & 0 & 0 & 0 & 0 & 0 & 0 & 0 & 0 & 0 \\
\hline $\mathrm{HOU}$ & 1 & 1 & 1 & 1 & 1 & 1 & 1 & 1 & 1 & 1 \\
\hline MWO & 11 & 25 & 14 & 48 & 25 & 18 & 45 & 32 & 12 & 27 \\
\hline NFM & 44 & 45 & 48 & 43 & 58 & 55 & 62 & 67 & & 79 \\
\hline OIL & 32 & 32 & 32 & 32 & 32 & 32 & 32 & 32 & 32 & \\
\hline OTH & 12 & 12 & 12 & 12 & 12 & 12 & 12 & 12 & 12 & 12 \\
\hline OTI & 15 & 15 & 15 & 15 & 15 & 15 & 15 & 15 & 15 & 15 \\
\hline PST & 9 & 9 & 9 & 9 & 9 & 9 & 9 & 9 & 9 & 9 \\
\hline RLW & 2 & 2 & 2 & 2 & 2 & 2 & 2 & 2 & 2 & 2 \\
\hline $\mathrm{SCl}$ & 3 & 3 & 3 & 3 & 3 & 3 & 3 & 3 & 3 & 3 \\
\hline TMS & 7 & 7 & 7 & 7 & 7 & 7 & 7 & 7 & 7 & 7 \\
\hline TPP & 7 & 77 & 33 & 48 & 11 & 17 & 5 & 30 & 12 & 33 \\
\hline TRD & 1 & 1 & 1 & 1 & 1 & 1 & 1 & 1 & 1 & 1 \\
\hline TRK & 2 & 2 & 2 & 2 & 2 & 2 & 2 & 2 & 2 & 2 \\
\hline TRO & 5 & 5 & 5 & 5 & 5 & 5 & 5 & 5 & 5 & 5 \\
\hline CLI & 11 & 11 & 11 & 11 & 11 & 11 & 11 & 11 & 11 & 11 \\
\hline Total & 364 & 534 & 474 & 545 & 488 & 477 & 397 & 459 & 357 & 510 \\
\hline
\end{tabular}

See Tables 1 and 2 for sector and region definitions.

Source: Roskomstat unpublished surveys and authors' calculations. 
Table 9: Imports by Product and by Regional Market (in $\times 2001$ rubles)

\begin{tabular}{|c|c|c|c|c|c|c|c|c|c|c|}
\hline Good & Central & Far East & North & Siberia & South & Urals & Moscow & $\begin{array}{r}\text { St. } \\
\text { Petersb. }\end{array}$ & Tumen & $\begin{array}{r}\text { North- } \\
\text { west }\end{array}$ \\
\hline AGR & 4.6 & 1.4 & 0.8 & 4.3 & 5.0 & 7.6 & 7.9 & 2.0 & 1.3 & 0.8 \\
\hline AIR & 0.3 & 0.1 & 0.1 & 0.4 & 0.3 & 0.6 & 0.9 & 0.1 & 0.2 & 0.1 \\
\hline $\mathrm{CHM}$ & 12.5 & 4.0 & 2.8 & 18.8 & 9.7 & 25.5 & 47.9 & 8.9 & 4.9 & 3.6 \\
\hline CNM & 2.7 & 0.5 & 0.4 & 3.3 & 2.8 & 4.6 & 11.6 & 2.2 & 0.8 & 0.7 \\
\hline COL & 0.6 & 0.2 & 0.2 & 1.3 & 0.4 & 1.2 & 0.6 & 0.2 & 0.2 & 0.2 \\
\hline CON & 8.0 & 4.0 & 3.4 & 10.2 & 10.0 & 20.4 & 15.3 & 4.7 & 16.4 & 1.7 \\
\hline CRU & 1.5 & 0.6 & 0.2 & 2.2 & 1.4 & 5.1 & 0.6 & 0.9 & 1.1 & 0.0 \\
\hline ELE & 0.3 & 0.1 & 0.1 & 0.4 & 0.3 & 0.8 & 0.5 & 0.1 & 0.2 & 0.1 \\
\hline FIN & 1.6 & 0.6 & 0.5 & 2.2 & 1.6 & 3.7 & 4.2 & 0.8 & 1.7 & 0.3 \\
\hline FME & 9.5 & 1.2 & 0.8 & 3.1 & 7.8 & 11.7 & 13.4 & 4.3 & 2.9 & 2.8 \\
\hline FOO & 19.1 & 7.2 & 3.0 & 14.4 & 17.9 & 25.3 & 79.1 & 36.2 & 4.2 & 7.7 \\
\hline GAS & 0.1 & 0.0 & 0.0 & 0.1 & 0.1 & 0.3 & 0.2 & 0.0 & 0.2 & 0.0 \\
\hline HEA & 0.9 & 0.4 & 0.3 & 1.3 & 1.0 & 2.3 & 2.8 & 0.5 & 0.9 & 0.2 \\
\hline $\mathrm{HOU}$ & 3.5 & 1.4 & 1.1 & 4.6 & 3.9 & 8.0 & 10.7 & 1.8 & 2.2 & 0.7 \\
\hline MWO & 35.8 & 14.3 & 8.2 & 18.0 & 31.1 & 60.3 & 198.5 & 49.6 & 20.1 & 10.9 \\
\hline NFM & 3.9 & 2.1 & 1.5 & 13.2 & 4.7 & 10.9 & 9.2 & 3.5 & 2.2 & 1.2 \\
\hline OIL & 4.1 & 1.1 & 1.0 & 4.5 & 4.0 & 9.0 & 6.4 & 1.6 & 3.3 & 0.8 \\
\hline OTH & 1.7 & 0.6 & 0.5 & 2.2 & 1.7 & 4.1 & 3.7 & 0.8 & 2.0 & 0.4 \\
\hline OTI & 1.2 & 0.3 & 0.2 & 1.1 & 1.1 & 2.1 & 1.5 & 0.4 & 0.6 & 0.2 \\
\hline PST & 0.1 & 0.0 & 0.0 & 0.1 & 0.1 & 0.2 & 0.2 & 0.0 & 0.1 & 0.0 \\
\hline RLW & 0.1 & 0.0 & 0.0 & 0.2 & 0.1 & 0.3 & 0.3 & 0.1 & 0.2 & 0.0 \\
\hline $\mathrm{SCl}$ & 0.0 & 0.0 & 0.0 & 0.0 & 0.0 & 0.1 & 0.1 & 0.0 & 0.0 & 0.0 \\
\hline TMS & 0.8 & 0.3 & 0.2 & 1.0 & 0.8 & 1.8 & 2.0 & 0.4 & 0.7 & 0.2 \\
\hline TPP & 2.7 & 0.6 & 1.1 & 0.7 & 3.6 & 2.0 & 22.1 & 7.3 & 0.1 & 2.8 \\
\hline TRD & 1.0 & 0.4 & 0.3 & 1.5 & 1.1 & 2.6 & 2.4 & 0.5 & 1.5 & 0.2 \\
\hline TRK & 0.4 & 0.1 & 0.1 & 0.5 & 0.4 & 0.9 & 0.9 & 0.2 & 0.5 & 0.1 \\
\hline TRO & 0.1 & 0.0 & 0.0 & 0.2 & 0.2 & 0.3 & 0.3 & 0.1 & 0.2 & 0.0 \\
\hline CLI & 25 & 10 & 8 & 32 & 29 & 56 & 84 & 13 & 13 & 5 \\
\hline Total & 142 & 52 & 35 & 142 & 140 & 268 & 528 & 140 & 81 & 41 \\
\hline
\end{tabular}

See Tables 1 and 2 for sector and region definitions.

Source: Roskomstat unpublished surveys and authors' calculations. 
Table 10. Sector Imports as a Percent of Total Imports of the Regional Market

\begin{tabular}{|c|c|c|c|c|c|c|c|c|c|c|}
\hline Good & Central & Far East & North & Siberia & South & Urals & Moscow & $\begin{array}{r}\text { St. } \\
\text { Petersb. }\end{array}$ & Tumen & $\begin{array}{r}\text { North- } \\
\text { west }\end{array}$ \\
\hline AGR & 3 & 3 & 2 & 3 & 4 & 3 & 1 & 1 & 2 & 2 \\
\hline AIR & 0 & 0 & 0 & 0 & 0 & 0 & 0 & 0 & 0 & 0 \\
\hline $\mathrm{CHM}$ & 9 & 8 & 8 & 13 & 7 & 10 & 9 & 6 & 6 & 9 \\
\hline CNM & 2 & 1 & 1 & 2 & 2 & 2 & 2 & 2 & 1 & 2 \\
\hline COL & 0 & 0 & 1 & 1 & 0 & 0 & 0 & 0 & 0 & 1 \\
\hline CON & 6 & 8 & 10 & 7 & 7 & 8 & 3 & 3 & 20 & 4 \\
\hline CRU & 1 & 1 & 1 & 2 & 1 & 2 & 0 & 1 & 1 & 0 \\
\hline ELE & 0 & 0 & 0 & 0 & 0 & 0 & 0 & 0 & 0 & 0 \\
\hline FIN & 1 & 1 & 2 & 2 & 1 & 1 & 1 & 1 & 2 & 1 \\
\hline FME & 7 & 2 & 2 & 2 & 6 & 4 & 3 & 3 & 4 & 7 \\
\hline FOO & 13 & 14 & 9 & 10 & 13 & 9 & 15 & 26 & 5 & 19 \\
\hline GAS & 0 & 0 & 0 & 0 & 0 & 0 & 0 & 0 & 0 & 0 \\
\hline HEA & 1 & 1 & 1 & 1 & 1 & 1 & 1 & 0 & 1 & 0 \\
\hline $\mathrm{HOU}$ & 2 & 3 & 3 & 3 & 3 & 3 & 2 & 1 & 3 & 2 \\
\hline MWO & 25 & 28 & 23 & 13 & 22 & 23 & 38 & 35 & 25 & 27 \\
\hline NFM & 3 & 4 & 4 & 9 & 3 & 4 & 2 & 2 & 3 & 3 \\
\hline OIL & 3 & 2 & 3 & 3 & 3 & 3 & 1 & 1 & 4 & 2 \\
\hline OTH & 1 & 1 & 1 & 2 & 1 & 2 & 1 & 1 & 2 & 1 \\
\hline OTI & 1 & 1 & 1 & 1 & 1 & 1 & 0 & 0 & 1 & 0 \\
\hline PST & 0 & 0 & 0 & 0 & 0 & 0 & 0 & 0 & 0 & 0 \\
\hline RLW & 0 & 0 & 0 & 0 & 0 & 0 & 0 & 0 & 0 & 0 \\
\hline $\mathrm{SCl}$ & 0 & 0 & 0 & 0 & 0 & 0 & 0 & 0 & 0 & 0 \\
\hline TMS & 1 & 1 & 1 & 1 & 1 & 1 & 0 & 0 & 1 & 0 \\
\hline TPP & 2 & 1 & 3 & 1 & 3 & 1 & 4 & 5 & 0 & 7 \\
\hline TRD & 1 & 1 & 1 & 1 & 1 & 1 & 0 & 0 & 2 & 1 \\
\hline TRK & 0 & 0 & 0 & 0 & 0 & 0 & 0 & 0 & 1 & 0 \\
\hline TRO & 0 & 0 & 0 & 0 & 0 & 0 & 0 & 0 & 0 & 0 \\
\hline CLI & 17 & 20 & 22 & 23 & 21 & 21 & 16 & 9 & 15 & 13 \\
\hline Total & 142 & 52 & 35 & 142 & 140 & 268 & 528 & 140 & 81 & 41 \\
\hline
\end{tabular}

See Tables 1 and 2 for sector and region definitions.

Source: Roskomstat unpublished surveys and authors' calculations. 
Table 11. Sector Import Intensities by Regional Market: Regional Imports of the Sector as a Percent of Regional Consumption of the Product

\begin{tabular}{|c|c|c|c|c|c|c|c|c|c|c|}
\hline Good & Central & Far East & North & Siberia & South & Urals & Moscow & $\begin{array}{r}\text { St. } \\
\text { Petersb. }\end{array}$ & Tumen & $\begin{array}{l}\text { North- } \\
\text { west }\end{array}$ \\
\hline AGR & 4 & 4 & 4 & 4 & 4 & 4 & 4 & 4 & 4 & 4 \\
\hline AIR & 3 & 3 & 3 & 3 & 3 & 3 & 3 & 3 & 3 & 3 \\
\hline $\mathrm{CHM}$ & 35 & 36 & 30 & 47 & 29 & 33 & 74 & 58 & 19 & 57 \\
\hline CNM & 13 & 16 & 13 & 18 & 10 & 11 & 29 & 25 & 8 & 20 \\
\hline $\mathrm{COL}$ & 7 & 7 & 7 & 7 & 7 & 7 & 7 & 7 & 7 & 7 \\
\hline $\mathrm{CON}$ & 8 & 8 & 8 & 8 & 8 & 8 & 8 & 8 & 8 & 8 \\
\hline CRU & 5 & 5 & 5 & 5 & 5 & 5 & 5 & 5 & 5 & 5 \\
\hline ELE & 1 & 1 & 1 & 1 & 1 & 1 & 1 & 1 & 1 & 1 \\
\hline FIN & 1 & 1 & 1 & 1 & 1 & 1 & 1 & 1 & 1 & 1 \\
\hline FME & 32 & 17 & 19 & 14 & 36 & 17 & 38 & 37 & 25 & 75 \\
\hline FOO & 25 & 23 & 13 & 15 & 20 & 15 & 31 & 94 & 10 & 50 \\
\hline GAS & 2 & 2 & 2 & 2 & 2 & 2 & 2 & 2 & 2 & 2 \\
\hline HEA & 1 & 1 & 1 & 1 & 1 & 1 & 1 & 1 & 1 & 1 \\
\hline $\mathrm{HOU}$ & 8 & 8 & 8 & 8 & 8 & 8 & 8 & 8 & 8 & 8 \\
\hline MWO & 36 & 37 & 24 & 15 & 27 & 26 & 98 & 100 & 16 & 53 \\
\hline NFM & 16 & 40 & 41 & 96 & 35 & 23 & 39 & 41 & 23 & 25 \\
\hline OIL & 8 & 8 & 8 & 8 & 8 & 8 & 8 & 8 & 8 & 8 \\
\hline OTH & 19 & 19 & 19 & 19 & 19 & 19 & 19 & 19 & 19 & 19 \\
\hline OTI & 7 & 6 & 6 & 6 & 6 & 6 & 7 & 7 & 6 & 6 \\
\hline PST & 2 & 2 & 2 & 2 & 2 & 2 & 2 & 2 & 2 & 2 \\
\hline RLW & 0 & 0 & 0 & 0 & 0 & 0 & 0 & 0 & 1 & 0 \\
\hline $\mathrm{SCl}$ & 0 & 0 & 0 & 0 & 0 & 0 & 0 & 0 & 0 & 0 \\
\hline TMS & 6 & 6 & 6 & 6 & 6 & 6 & 6 & 6 & 6 & 6 \\
\hline TPP & 13 & 11 & 28 & 4 & 19 & 5 & 60 & 83 & 1 & 78 \\
\hline TRD & 0 & 0 & 0 & 0 & 0 & 0 & 0 & 0 & 0 & 0 \\
\hline TRK & 2 & 2 & 2 & 2 & 2 & 2 & 2 & 2 & 2 & 2 \\
\hline TRO & 1 & 1 & 1 & 1 & 1 & 1 & 1 & 1 & 1 & 1 \\
\hline CLI & 73 & 73 & 73 & 73 & 73 & 73 & 73 & 73 & 73 & 73 \\
\hline Total & 142 & 52 & 35 & 142 & 140 & 268 & 528 & 140 & 81 & 41 \\
\hline
\end{tabular}

See Tables 1 and 2 for sector and region definitions.

Source: Roskomstat unpublished surveys and authors' calculations. 
Table 12a. Tariff Rates, Export Tax Rates, Estimated Ad Valorem Equivalence of Barriers to FDI in Services Sectors and Estimated Improved Market Access (ad-valorem in \%) -- by sector

\begin{tabular}{|c|c|c|c|c|c|}
\hline & \multirow[b]{2}{*}{ Tariff rates } & \multirow[b]{2}{*}{$\begin{array}{c}\text { Export tax } \\
\text { rates }\end{array}$} & \multirow{2}{*}{$\begin{array}{c}\text { Estimated } \\
\text { change in } \\
\text { world market } \\
\text { price }\end{array}$} & \multicolumn{2}{|c|}{$\begin{array}{c}\text { Equivalent } \% \text { barriers } \\
\text { to FDI }\end{array}$} \\
\hline & & & & Base Year & $\begin{array}{l}\text { Post-WTO } \\
\text { Accession }\end{array}$ \\
\hline Electric industry & 2.6 & 0.0 & 0.0 & & \\
\hline Oil extraction & 0.0 & 7.9 & 0.0 & & \\
\hline Oil processing & 4.5 & 4.6 & 0.0 & & \\
\hline Gas & 5.0 & 18.8 & 0.0 & & \\
\hline Coalmining & 2.2 & 0.0 & 0.0 & & \\
\hline Other fuel industries & 5.0 & 2.6 & 0.0 & & \\
\hline Ferrous metallurgy & 5.9 & 0.4 & 1.5 & & \\
\hline Non-ferrous metallurgy & 8.5 & 5.3 & 1.5 & & \\
\hline Chemical \& oil-chemical industry & 7.5 & 1.6 & 1.5 & & \\
\hline Mechanical engineering \& metal-working & 10.7 & 0.0 & 0.0 & & \\
\hline Timber \& woodworking \& pulp \& paper industry & 13.5 & 6.9 & 0.0 & & \\
\hline Construction materials industry & 12.0 & 1.6 & 0.0 & & \\
\hline Textiles and Apparel & 16.8 & 4.1 & 0.5 & & \\
\hline Food industry & 14.1 & 3.1 & 0.5 & & \\
\hline Other industries & 12.4 & 0.0 & 0.5 & & \\
\hline Agriculture \& forestry & 8.4 & 0.6 & 0.0 & & \\
\hline Other goods-producing sectors & 14.6 & 0.0 & 0.5 & & \\
\hline Telecommunications & & & & 33.0 & 0.0 \\
\hline Science \& science servicing (market) & & & & 33.0 & 0.0 \\
\hline Financial services & & & & 36.0 & 0.0 \\
\hline Railway transportation & & & & 33.0 & 0.0 \\
\hline Truck transportation & & & & 33.0 & 0.0 \\
\hline Pipelines transportation & & & & 33.0 & 0.0 \\
\hline Maritime transportation & & & & 95.0 & 80.0 \\
\hline Air transportation & & & & 90.0 & 75.0 \\
\hline Other transportation & & & & 33.0 & 0.0 \\
\hline
\end{tabular}

Source: Tarr, Shepotylo and Koudoyarov (2005) for tariff rates; Kimura et al. (2004a,b,c) for barriers to FDI; Roskomstat for export tax rates; authors' estimates for change in world market prices. 
Table 12b. Shares of Business Services Sectors in the Regions of Russia Captured by Multinational Firms (ad-valorem in \%) -- by sector

\begin{tabular}{l|ccccccccc}
\hline & Maritime & Rail & Truck & Pipeline & Air & Transp. & Telecom & Science & Financial \\
\hline Moscow & 0.47 & 0.02 & 0.03 & 0.06 & 0.11 & 0.02 & 0.08 & 0.07 & 0.13 \\
St. Petersburg & 0.70 & 0.06 & 0.10 & 0.06 & 0.50 & 0.08 & 0.30 & 0.20 & 0.18 \\
Tumen & 0.29 & 0.04 & 0.05 & 0.01 & 0.46 & 0.04 & 0.20 & 0.12 & 0.08 \\
Northwest & 0.70 & 0.06 & 0.10 & 0.06 & 0.50 & 0.08 & 0.30 & 0.20 & 0.20 \\
North & 0.70 & 0.06 & 0.10 & 0.06 & 0.50 & 0.08 & 0.30 & 0.20 & 0.20 \\
Central & 0.41 & 0.03 & 0.07 & 0.05 & 0.35 & 0.05 & 0.20 & 0.09 & 0.09 \\
South & 0.46 & 0.04 & 0.06 & 0.05 & 0.30 & 0.05 & 0.19 & 0.10 & 0.09 \\
Urals & 0.15 & 0.02 & 0.03 & 0.02 & 0.16 & 0.03 & 0.09 & 0.07 & 0.04 \\
Siberia & 0.28 & 0.02 & 0.05 & 0.03 & 0.26 & 0.04 & 0.15 & 0.09 & 0.07 \\
Far East & 0.70 & 0.06 & 0.10 & 0.06 & 0.50 & 0.08 & 0.30 & 0.20 & 0.20 \\
& & & & & & & & & \\
National average & 0.35 & 0.03 & 0.05 & 0.03 & 0.25 & 0.04 & 0.15 & 0.10 & 0.10 \\
& & & & & & & & & \\
\hline
\end{tabular}


Table 13a. Impact of WTO Accession on Regional Markets (\% change from base year)

\begin{tabular}{|c|c|c|c|c|c|c|c|c|c|c|c|}
\hline & $\begin{array}{r}\text { Overall } \\
\text { average }\end{array}$ & Moscow & $\begin{array}{r}\text { St. } \\
\text { Peters. }\end{array}$ & Tumen & $\begin{array}{r}\text { North- } \\
\text { west } \\
\end{array}$ & North & Central & South & Urals & Siberia & $\begin{array}{l}\text { Far } \\
\text { East }\end{array}$ \\
\hline \multicolumn{12}{|l|}{ Aggregate welfare } \\
\hline Welfare (EV as \% of consumption) & 7.8 & 7.0 & 10.6 & 13.8 & 11.2 & 9.8 & 7.6 & 8.3 & 6.2 & 7.6 & 9.7 \\
\hline Welfare (EV as \% of GDP) & 4.3 & 4.7 & 5.7 & 3.1 & 6.2 & 4.7 & 4.2 & 4.7 & 3.3 & 4.2 & 5.2 \\
\hline \multicolumn{12}{|l|}{ Aggregate trade } \\
\hline Regional terms of trade ( $\%$ change) & 3.3 & 4.9 & 6.4 & 4.4 & 6.1 & 5.2 & 4.8 & 4.4 & 3.7 & 3.6 & 5.4 \\
\hline Regional exports (\% change) & 1.9 & 2.6 & 2.1 & 1.8 & 2.1 & 2.2 & 2.2 & 1.7 & 1.6 & 1.6 & 2.4 \\
\hline Real exchange rate ( $\%$ change) & 2.5 & 2.6 & 3.4 & 2.7 & 2.9 & 2.7 & 2.8 & 2.8 & 1.9 & 1.9 & 3.0 \\
\hline International exports ( $\%$ change) & 9.4 & 13.3 & 19.1 & 2.8 & 17.3 & 7.7 & 23.0 & 10.9 & 10.8 & 8.0 & 11.1 \\
\hline \multicolumn{12}{|l|}{ Return to primary factors (\% change) } \\
\hline Unskilled labor & 4.1 & 4.7 & 6.6 & 4.2 & 6.1 & 5.5 & 3.8 & 4.9 & 2.5 & 4.1 & 6.2 \\
\hline Skilled labor & 4.2 & 3.5 & 7.4 & 3.8 & 7.2 & 5.7 & 5.3 & 5.1 & 2.9 & 4.4 & 6.9 \\
\hline National capital & 4.0 & 4.2 & 4.9 & 4.2 & 4.4 & 4.2 & 4.4 & 4.3 & 3.4 & 3.4 & 4.6 \\
\hline Regional mobile capital & 6.5 & 6.6 & 10.2 & 5.4 & 10.2 & 7.6 & 6.9 & 6.5 & 5.5 & 6.1 & 8.0 \\
\hline Crude oil resources & 4.9 & & & 5.6 & 4.1 & 5.3 & & 5.4 & 2.9 & 2.8 & 5.9 \\
\hline Natural gas resources & 1.8 & & & 2.9 & -17.2 & -9.1 & & -5.0 & -9.9 & -12.3 & -9.1 \\
\hline Coal resources & 10.8 & & & & & 14.1 & 13.7 & 13.6 & 10.6 & 9.8 & 14.2 \\
\hline Specific capital in domestic firms & -24.7 & -32.3 & -26.4 & -47.5 & -23.7 & -27.4 & -19.7 & -26.3 & -18.6 & -21.0 & -30.4 \\
\hline Specific capital in multinational firms & 101.4 & 60.4 & 45.6 & 228.1 & 79.2 & 148.3 & 116.6 & 130.6 & 144.1 & 165.2 & 118.0 \\
\hline \multicolumn{12}{|l|}{ Factor adjustments } \\
\hline Unskilled labor (\% changing sectors) & 2.3 & 2.1 & 3.2 & 1.5 & 4.2 & 2.1 & 2.6 & 1.7 & 2.3 & 2.1 & 2.8 \\
\hline Skilled labor (\% changing sector) & 2.5 & 2.6 & 3.9 & 1.9 & 4.1 & 2.5 & 2.9 & 2.0 & 2.4 & 2.4 & 3.2 \\
\hline
\end{tabular}

Source: Authors' calculations. 
Table 13b. Impact of Full Foreign Direct Investment Liberalization in Services on Regional Markets: Welfare, Trade and Factor Market Effects

(\% change from base year)

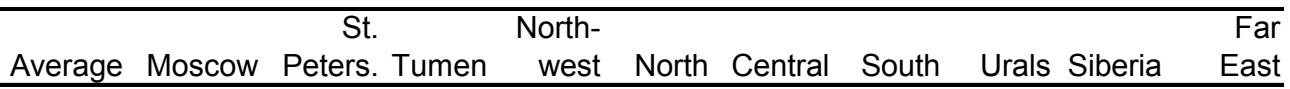

\section{Aggregate welfare}

Welfare (EV as \% of consumption)

$\begin{array}{rrrrrrrrrrr}6.7 & 5.5 & 8.4 & 11.5 & 9.0 & 8.9 & 7.3 & 7.2 & 5.9 & 6.8 & 8.4 \\ 3.7 & 3.8 & 4.5 & 2.6 & 5.0 & 4.3 & 4.1 & 4.1 & 3.2 & 3.8 & 4.5\end{array}$

Welfare (EV as \% of GDP)

Aggregate trade

Regional terms of trade (\% change)

$1.7 \quad 2.1 \quad 2.9$

Regional exports (\% change)

Real exchange rate (\% change)

International exports (\% change)

$1.8 \quad 2.1$

$1.1 \quad 1.0$

$\begin{array}{lllllllllll}2.9 & 5.1 & 5.5 & 2.5 & 5.6 & 3.1 & 5.2 & 2.6 & 1.8 & 2.3 & 4.1\end{array}$

Return to primary factors (\% change)

\begin{tabular}{|c|c|c|c|c|c|c|c|c|c|c|c|}
\hline Unskilled labor & 3.3 & 2.6 & 5.1 & 3.0 & 4.5 & 5.0 & 3.5 & 3.7 & 2.5 & 3.5 & 5.3 \\
\hline Skilled labor & 2.1 & 0.9 & 3.9 & 2.5 & 4.2 & 4.3 & 2.6 & 2.6 & 1.2 & 2.5 & 4.3 \\
\hline National capital & 2.1 & 1.9 & 2.6 & 2.5 & 2.4 & 2.6 & 2.1 & 2.1 & 1.8 & 2.1 & 2.4 \\
\hline Regional mobile capital & 3.8 & 3.4 & 5.6 & 3.9 & 5.8 & 5.2 & 4.3 & 4.2 & 2.9 & 3.5 & 5.3 \\
\hline Crude oil resources & 4.0 & & & 4.4 & 3.9 & 4.9 & & 3.8 & 2.6 & 3.8 & 4.5 \\
\hline Coal resources & 7.9 & & & & & 9.9 & 7.3 & 8.2 & 6.4 & 7.6 & 9.1 \\
\hline Specific capital in domestic firms & -20.4 & -27.4 & -19.1 & -47.7 & -18.2 & -23.8 & -14.2 & -22.2 & -14.0 & -18.7 & -25.1 \\
\hline Specific capital in multinational firms & 86.3 & 53.2 & 44.2 & 198.9 & 68.4 & 126.9 & 96.6 & 106.1 & 118.6 & 137.5 & 100.1 \\
\hline Skilled labor (\% changing sector) & 1.8 & 2.0 & 2.3 & 1.8 & 2.2 & 2.4 & 1.6 & 1.4 & 1.6 & 2.0 & 2.5 \\
\hline
\end{tabular}

See Table 2 for definition of regional markets

Source: Authors' estimates 
Table 13c. Impact of Partial Foreign Direct Investment Liberalization in Services on Regional Markets: Welfare, Trade and Factor Market Effects

(\% change from base year)

\begin{tabular}{ccrrrrr} 
& St. & North- & & & Far \\
Average Moscow & Peters. Tumen & west & North Central & South & Urals Siberia & East \\
\hline
\end{tabular}

Aggregate welfare

Welfare (EV as \% of consumption)

Welfare (EV as \% of GDP)

$\begin{array}{lllllllllll}4.2 & 4.3 & 6.0 & 6.4 & 6.1 & 4.8 & 3.7 & 4.5 & 3.2 & 4.0 & 5.1 \\ 2.4 & 2.9 & 3.2 & 1.5 & 3.4 & 2.3 & 2.0 & 2.6 & 1.7 & 2.2 & 2.7\end{array}$

Aggregate trade

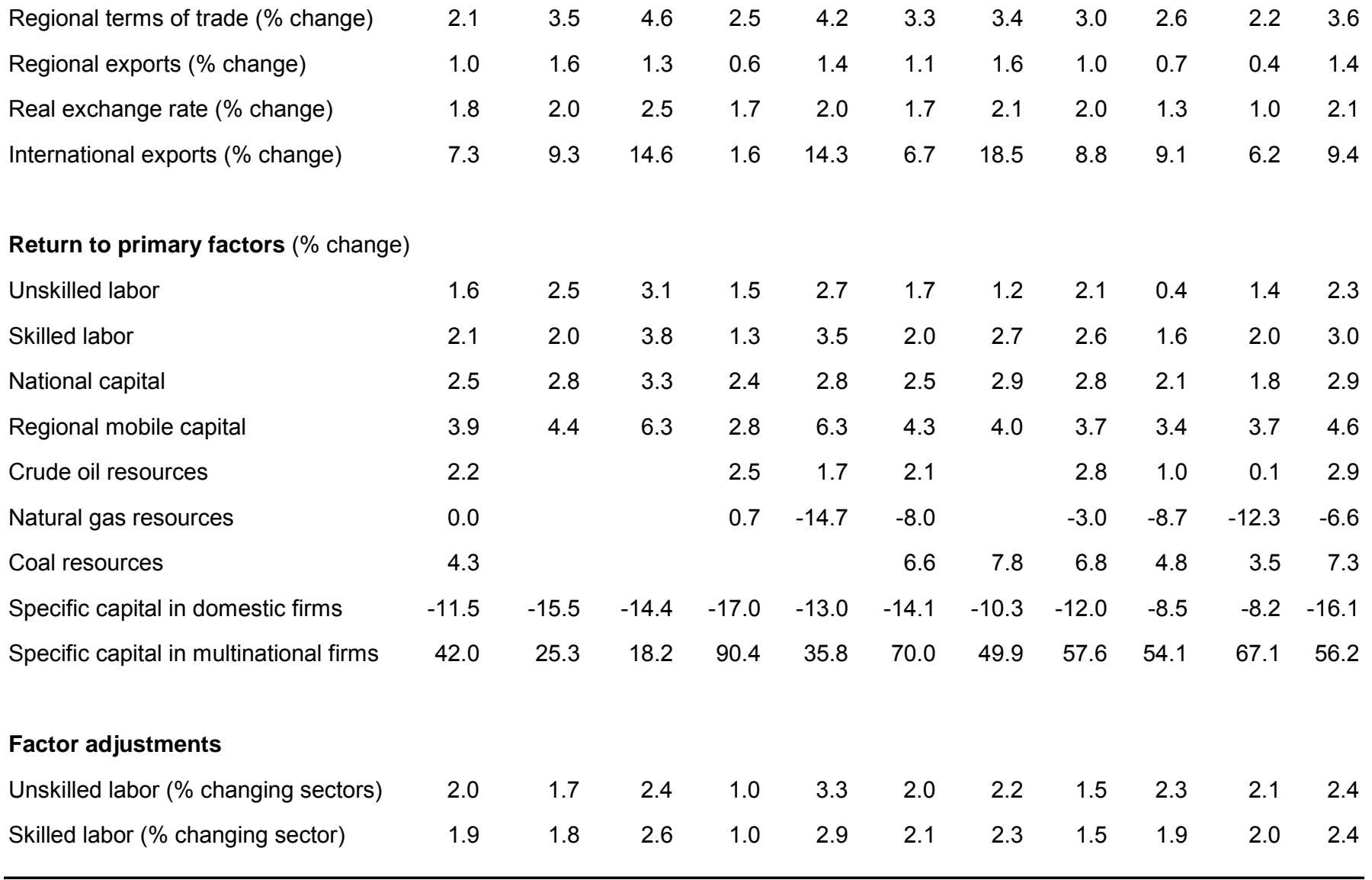

See Table 2 for definition of regional markets

Source: Authors' estimates 
Table 13d. Impact of Improved External Market Access on Regional Markets: Welfare, Trade and Factor Market Effects

(\% change from base year)

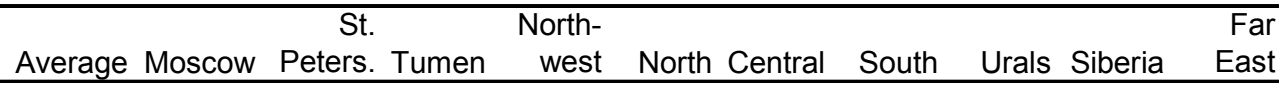

\section{Aggregate welfare}

Welfare (EV as \% of consumption)

$0.3 \quad 0.5 \quad 0.5$

Welfare (EV as \% of GDP)

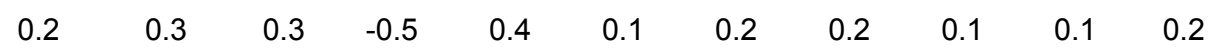

\section{Aggregate trade}

Regional terms of trade (\% change)

$\begin{array}{rrrrrrrrrrr}0.1 & -0.4 & -0.4 & -0.6 & -0.4 & -0.6 & -0.5 & -0.5 & -0.6 & -0.7 & -0.3 \\ 0.0 & 0.2 & 0.1 & -0.3 & 0.2 & -0.2 & 0.1 & 0.1 & -0.1 & -0.2 & 0.1 \\ -0.6 & -0.5 & -0.5 & -0.4 & -0.7 & -0.6 & -0.6 & -0.6 & -0.8 & -0.9 & -0.4 \\ 0.6 & -1.0 & 1.2 & 0.3 & 3.2 & -0.1 & 2.6 & 0.0 & 1.4 & 0.5 & -1.8\end{array}$

International exports (\% change)

\section{Return to primary factors (\% change)}

Unskilled labor

Skilled labor

National capital

Regional mobile capital

Crude oil resources

Natural gas resources

Coal resources

Specific capital in domestic firms

Specific capital in multinational firms

$\begin{array}{rrrrrrrrrrr}-0.3 & -0.1 & -0.2 & -0.3 & -0.2 & -0.4 & -0.2 & 0.0 & -0.3 & -0.6 & -0.4 \\ 0.0 & 0.2 & 0.3 & -0.4 & 0.2 & -0.2 & 0.2 & 0.1 & 0.1 & -0.3 & -0.2 \\ 0.2 & 0.3 & 0.3 & 0.4 & 0.0 & 0.2 & 0.1 & 0.2 & 0.0 & -0.1 & 0.4 \\ 0.4 & 0.4 & 0.7 & -0.4 & 0.9 & 0.3 & 0.5 & 0.3 & 0.5 & 0.5 & 0.2 \\ -1.4 & & & -0.9 & -2.5 & -1.9 & & -1.8 & -2.3 & -2.7 & -1.1 \\ -2.5 & & & -1.6 & -13.9 & -9.3 & & -9.3 & -11.8 & -12.9 & -6.3 \\ -1.7 & & & & & -0.8 & -1.0 & -0.8 & -1.2 & -2.1 & -0.1 \\ -0.4 & -0.5 & -0.8 & -0.1 & -1.2 & -0.1 & -0.7 & -0.3 & -0.6 & 0.1 & 0.3 \\ 2.0 & 0.4 & -0.3 & 4.5 & 1.6 & 2.9 & 3.2 & 3.7 & 3.9 & 5.0 & 2.1\end{array}$

\section{Factor adjustments}

\begin{tabular}{|c|c|c|c|c|c|c|c|c|c|c|}
\hline Unskilled labor (\% changing sectors) & 0.7 & 0.5 & 0.8 & 0.3 & 1.2 & 0.8 & 0.5 & 0.3 & 0.8 & 1.1 \\
\hline Skilled labor (\% changing sector) & 0.7 & 0.4 & 0.8 & 0.3 & 1.1 & 0.9 & 0.5 & 0.3 & 0.8 & 1.1 \\
\hline
\end{tabular}

See Table 2 for definition of regional markets

Source: Authors' estimates 
Table 13e. Impact of Tariff Reductions on Regional Markets of Russia: Welfare, Trade and Factor Market Effects

(\% change from base year)

\begin{tabular}{|c|c|c|c|c|c|c|c|c|c|c|c|}
\hline & Average & Moscow & $\begin{array}{r}\text { St. } \\
\text { Peters. }\end{array}$ & Tumen & $\begin{array}{r}\text { North- } \\
\text { west } \\
\end{array}$ & North & Central & South & Urals & Siberia & $\begin{array}{r}\text { Far } \\
\text { East } \\
\end{array}$ \\
\hline \multicolumn{12}{|l|}{ Aggregate welfare } \\
\hline Welfare (EV as \% of consumption) & 0.7 & 0.9 & 1.6 & 4.6 & 1.4 & 0.7 & -0.2 & 0.7 & -0.1 & 0.6 & 0.9 \\
\hline Welfare (EV as $\%$ of GDP) & 0.4 & 0.6 & 0.9 & 1.0 & 0.8 & 0.3 & -0.1 & 0.4 & 0.0 & 0.3 & 0.5 \\
\hline \multicolumn{12}{|l|}{ Aggregate trade } \\
\hline Regional terms of trade ( $\%$ change) & 1.4 & 3.1 & 3.9 & 1.9 & 3.5 & 2.6 & 3.2 & 2.8 & 2.6 & 2.3 & 2.7 \\
\hline Regional exports (\% change) & 0.2 & 0.2 & 0.2 & 0.1 & 0.3 & 0.1 & 0.7 & 0.2 & 0.2 & -0.3 & 0.2 \\
\hline Real exchange rate (\% change) & 2.0 & 2.1 & 2.5 & 1.4 & 2.3 & 1.6 & 2.4 & 2.1 & 1.8 & 1.5 & 1.7 \\
\hline International exports (\% change) & 5.5 & 9.3 & 9.0 & 0.1 & 8.2 & 4.8 & 13.1 & 7.7 & 7.3 & 5.1 & 9.6 \\
\hline \multicolumn{12}{|l|}{ Return to primary factors (\% change) } \\
\hline Unskilled labor & 1.2 & 2.2 & 2.2 & 1.4 & 1.8 & 0.9 & 0.6 & 1.2 & 0.3 & 1.3 & 1.3 \\
\hline Skilled labor & 2.0 & 2.2 & 2.8 & 1.6 & 2.7 & 1.6 & 2.3 & 2.2 & 1.6 & 1.9 & 2.6 \\
\hline National capital & 1.7 & 1.8 & 2.2 & 1.2 & 2.0 & 1.3 & 2.1 & 1.8 & 1.5 & 1.2 & 1.5 \\
\hline Regional mobile capital & 2.2 & 2.7 & 3.3 & 1.9 & 3.1 & 2.1 & 1.9 & 1.9 & 2.0 & 1.9 & 2.5 \\
\hline Crude oil resources & 2.3 & & & 1.9 & 3.0 & 2.2 & & 3.6 & 2.8 & 1.7 & 2.0 \\
\hline Natural gas resources & 1.2 & & & 0.7 & 1.6 & 2.5 & & 9.9 & 6.1 & 1.2 & 0.2 \\
\hline Coal resources & 3.2 & & & & & 3.6 & 6.5 & 5.0 & 4.4 & 3.0 & 3.3 \\
\hline Specific capital in domestic firms & -3.4 & -3.7 & -4.6 & 0.7 & -3.5 & -3.3 & -4.2 & -3.2 & -3.7 & -2.0 & -5.4 \\
\hline Specific capital in multinational firms & 10.9 & 5.8 & 1.0 & 21.0 & 6.6 & 15.5 & 13.5 & 17.4 & 18.6 & 19.3 & 13.7 \\
\hline \multicolumn{12}{|l|}{ Factor adjustments } \\
\hline Unskilled labor (\% changing sectors) & 1.3 & 1.0 & 1.2 & 0.6 & 1.6 & 1.0 & 1.5 & 1.1 & 1.5 & 1.1 & 2.4 \\
\hline Skilled labor (\% changing sector) & 0.9 & 0.8 & 1.0 & 0.4 & 1.0 & 0.8 & 1.4 & 0.8 & 1.0 & 0.8 & 2.0 \\
\hline
\end{tabular}

See Table 2 for definition of regional markets

Source: Authors' estimates 
Table 14. Decomposition of Welfare Impacts for the Regional Markets - WTO Scenario

Component effects on welfare (EV) as a percent of consumption

\begin{tabular}{rrr} 
St. & North- & Far \\
Average Moscow & Peters. Tumen & west North Central South Urals Siberia East \\
\hline
\end{tabular}

Wages

Skilled wages

Unskilled wages

\section{Capital Earnings}

National capital

Regional mobile capital

Regional energy rents

Specific capital in domestic firms

Specific capital in multinational firms

\begin{tabular}{|c|c|c|c|c|c|c|c|c|c|}
\hline 0.7 & 0.3 & 1.2 & 1.9 & 1.5 & 1.1 & 1.1 & 0.9 & 0.6 & 0.9 \\
\hline$\theta$ & 1.0 & 2.5 & 3.7 & 2.9 & 2.1 & 2.0 & 2.0 & 1.2 & 1.8 \\
\hline
\end{tabular}

$\begin{array}{rrrrrrrrrrr}2.7 & 4.1 & 3.9 & -0.2 & 1.7 & 3.5 & 1.5 & 2.9 & 1.3 & 1.5 & 4.3 \\ 3.2 & 1.7 & 4.6 & 7.9 & 6.2 & 3.7 & 4.3 & 3.2 & 3.3 & 3.6 & 3.3 \\ 0.2 & & & 4.2 & 0.0 & 0.4 & 0.0 & 0.2 & 0.1 & 0.2 & 0.2 \\ -1.9 & -1.3 & -2.4 & -5.2 & -2.7 & -2.4 & -2.5 & -1.8 & -2.0 & -1.9 & -2.1 \\ 1.0 & 0.7 & 1.1 & 2.9 & 1.4 & 1.3 & 1.2 & 1.0 & 1.0 & 1.1 & 1.1\end{array}$

Tax and Terms of Trade Effects

\begin{tabular}{|c|c|c|c|c|c|c|c|c|c|c|c|}
\hline Regional investment & -0.4 & -0.1 & -0.7 & -2.7 & -0.5 & -0.7 & -0.5 & -0.5 & -0.2 & -0.3 & -0.7 \\
\hline Value of stock changes & 0.4 & 0.4 & 0.5 & 1.1 & 0.6 & 0.6 & 0.4 & 0.3 & 0.3 & 0.4 & 0.5 \\
\hline Value of capital flows (terms of trade) & -0.9 & -1.0 & -1.3 & -1.0 & -1.1 & -1.0 & -1.1 & -1.0 & -0.7 & -0.7 & -1.1 \\
\hline Change in lumpsum taxes & 1.1 & 1.1 & 1.1 & 1.1 & 1.1 & 1.1 & 1.1 & 1.1 & 1.1 & 1.1 & \\
\hline Total Welfare Change ( $\%$ Consump) & 7.8 & 7.0 & 10.6 & 13.8 & 11.2 & 9.8 & 7.6 & 8.3 & 6.2 & 7.6 & \\
\hline
\end{tabular}

See Table 2 for definition of regional markets

Source: Authors' estimates 
Table 15. Impact of WTO Accession on Output by Sector and Regional Market (percentage change)

\begin{tabular}{|c|c|c|c|c|c|c|c|c|c|c|}
\hline Good & Central & Siberia & South & North & Urals & Far East & Moscow & $\begin{array}{r}\text { St. } \\
\text { Peters. }\end{array}$ & Tumen & $\begin{array}{r}\text { North- } \\
\text { west } \\
\end{array}$ \\
\hline FME & 33.1 & 13.1 & 44.8 & 23.7 & 15.2 & 19.7 & 43.6 & 352.3 & & 10.5 \\
\hline $\mathrm{CHM}$ & 8.3 & 21.5 & 10.4 & -1.9 & 12.7 & 0.1 & 2.9 & 4.9 & 45.3 & 28.6 \\
\hline NFM & 10.9 & 4.5 & 33.8 & 10.2 & 22.7 & 6.1 & 35.4 & -0.1 & & -11.6 \\
\hline TMS & 9.2 & 5.0 & 9.0 & 16.6 & -2.3 & 16.7 & -4.3 & 15.8 & 11.3 & 16.8 \\
\hline TRK & 7.7 & 5.3 & 6.9 & 9.6 & 3.1 & 11.2 & 2.9 & 10.8 & 7.0 & 11.9 \\
\hline $\mathrm{COL}$ & 5.6 & 3.7 & 5.5 & 5.7 & 4.8 & 5.2 & & & & \\
\hline TRD & 6.0 & 4.1 & 4.4 & 4.2 & 3.9 & 5.3 & 4.3 & 6.5 & 2.7 & 8.0 \\
\hline ELE & 1.9 & 1.6 & 1.8 & 1.0 & 1.4 & 0.7 & 0.4 & 1.9 & 0.3 & 4.0 \\
\hline $\mathrm{SCl}$ & -0.6 & 1.3 & -0.1 & 2.9 & -1.2 & 3.7 & -0.1 & 4.8 & -0.5 & 4.5 \\
\hline $\mathrm{HOU}$ & 0.9 & 1.2 & 1.9 & 1.8 & 0.4 & 1.9 & 1.4 & 1.3 & 2.2 & 1.6 \\
\hline PST & 1.5 & 1.0 & 2.0 & 1.6 & 0.5 & 2.1 & 1.0 & 1.1 & 1.7 & 1.6 \\
\hline HEA & 1.2 & 1.2 & 1.6 & 1.4 & 1.0 & 1.6 & 1.4 & 1.6 & 1.2 & 1.7 \\
\hline CRU & & 0.9 & 1.4 & 1.7 & 0.9 & 1.6 & & & 1.6 & 1.3 \\
\hline RLW & 3.2 & -0.1 & 0.9 & 0.4 & 0.8 & 0.8 & -1.1 & 4.6 & 0.7 & 2.6 \\
\hline OIL & 4.0 & -2.5 & 3.6 & 2.2 & -1.7 & 3.0 & -0.7 & -2.8 & 6.2 & \\
\hline GAS & & -1.4 & -0.2 & -0.5 & -1.0 & -0.6 & & & 1.1 & -1.9 \\
\hline CON & 0.5 & -1.6 & 0.6 & -1.4 & -0.1 & -1.4 & 1.6 & -2.7 & 2.2 & -4.7 \\
\hline TPP & -7.0 & -4.6 & -10.1 & -0.6 & -2.3 & 29.9 & -13.2 & -8.9 & 15.3 & -10.6 \\
\hline AIR & -1.4 & -5.1 & -1.4 & 1.1 & -3.4 & 0.6 & -2.5 & -2.6 & 4.8 & -2.7 \\
\hline CLI & -1.8 & -4.5 & -2.1 & -3.1 & -3.2 & -2.9 & -3.8 & -6.1 & 1.3 & -7.1 \\
\hline PIP & -2.4 & -4.6 & -3.1 & -4.6 & -2.8 & -4.6 & -5.9 & -6.0 & -0.2 & -1.3 \\
\hline MWO & -9.4 & 0.4 & -1.7 & -6.1 & -9.0 & -4.0 & 8.7 & -2.4 & -1.7 & -11.2 \\
\hline OTI & -3.8 & -6.2 & -2.6 & -4.5 & -4.3 & -5.9 & -0.3 & -3.6 & -1.5 & -6.0 \\
\hline AGR & -3.2 & -4.0 & -2.2 & -4.6 & -1.8 & -5.4 & -3.7 & -9.7 & 2.8 & -11.4 \\
\hline FIN & -6.2 & -6.7 & -6.1 & -6.6 & -6.7 & -6.3 & -6.6 & -6.0 & -7.1 & -5.3 \\
\hline MAR & -4.3 & -11.7 & -6.8 & -4.9 & -6.1 & -3.6 & -9.3 & -6.0 & -5.8 & -8.1 \\
\hline TRO & -6.2 & -11.0 & -7.5 & -2.3 & -15.6 & -1.8 & -19.4 & -2.2 & -10.0 & -1.1 \\
\hline CNM & -7.4 & -11.4 & -5.6 & -8.0 & -7.1 & -9.0 & -12.7 & -14.1 & 1.6 & -15.7 \\
\hline OTH & -7.0 & -13.9 & -8.7 & -13.3 & -6.9 & -14.7 & -7.0 & -17.2 & -4.6 & -21.1 \\
\hline FOO & -13.5 & -11.9 & -10.6 & -8.8 & -11.3 & -12.5 & -17.1 & -13.9 & 0.4 & -17.0 \\
\hline
\end{tabular}

See Tables 1 and 2 for sector and regional market definitions.

Source: Authors' calculations. 
Table 16. Impact of WTO Accession on Skilled Employment by Sector and Regional Market (percentage change)

\begin{tabular}{|c|c|c|c|c|c|c|c|c|c|c|}
\hline Good & Central & Siberia & South & North & Urals & Far East & Moscow & $\begin{array}{r}\text { St. } \\
\text { Peters. }\end{array}$ & Tumen & $\begin{array}{r}\text { North- } \\
\text { west }\end{array}$ \\
\hline FME & 33.4 & 13.7 & 45.0 & 24.0 & 16.5 & 19.4 & 45.9 & 355.6 & & 11.3 \\
\hline $\mathrm{CHM}$ & 8.4 & 22.1 & 10.6 & -1.6 & 14.0 & -0.1 & 4.8 & 5.6 & 46.1 & 29.5 \\
\hline NFM & 11.3 & 5.1 & 34.3 & 10.8 & 24.3 & 6.0 & 38.0 & 0.9 & & -10.7 \\
\hline TMS & 9.2 & 5.5 & 9.2 & 17.0 & -1.3 & 16.6 & -2.7 & 16.5 & 11.9 & 17.5 \\
\hline TRK & 7.1 & 5.2 & 6.6 & 9.3 & 3.5 & 10.5 & 3.9 & 10.7 & 7.1 & 11.6 \\
\hline $\mathrm{COL}$ & 8.0 & 5.3 & 8.0 & 8.0 & 7.6 & 6.9 & & & & \\
\hline TRD & 5.2 & 3.8 & 3.5 & 3.2 & 4.7 & 3.5 & 5.7 & 6.0 & 2.1 & 7.6 \\
\hline OIL & 5.0 & -1.5 & 4.4 & 3.3 & 0.0 & 3.5 & 1.5 & -1.2 & 7.3 & \\
\hline $\mathrm{HOU}$ & 1.3 & 1.9 & 2.4 & 2.5 & 1.8 & 2.0 & 3.5 & 2.4 & 3.0 & 2.7 \\
\hline ELE & 2.1 & 2.1 & 2.1 & 1.3 & 2.6 & 0.5 & 2.1 & 2.6 & 0.8 & 4.8 \\
\hline RLW & 3.2 & 0.3 & 1.1 & 0.7 & 1.6 & 0.6 & 0.3 & 5.2 & 1.2 & 3.1 \\
\hline $\mathrm{SCl}$ & -1.4 & 1.2 & -0.3 & 2.8 & -0.9 & 3.1 & 1.2 & 4.7 & -0.3 & 4.2 \\
\hline HEA & 0.4 & 1.2 & 1.4 & 1.2 & 1.3 & 0.9 & 2.7 & 1.4 & 1.5 & 1.3 \\
\hline CON & 0.3 & -1.3 & 0.6 & -1.3 & 0.6 & -1.7 & 3.0 & -2.4 & 2.6 & -4.5 \\
\hline CRU & & -1.5 & 0.3 & -0.4 & 0.1 & -0.9 & & & 1.7 & -2.9 \\
\hline PST & -0.9 & -0.7 & -0.3 & -1.1 & -0.1 & -1.2 & 1.1 & -1.2 & -0.4 & -0.8 \\
\hline TPP & -7.3 & -4.5 & -10.1 & -0.6 & -1.8 & 29.3 & -12.0 & -8.7 & 15.6 & -10.5 \\
\hline AIR & -2.8 & -5.8 & -2.4 & -0.1 & -3.7 & -1.0 & -2.1 & -3.9 & 4.2 & -4.1 \\
\hline CLI & -2.4 & -4.3 & -2.0 & -3.0 & -2.8 & -3.2 & -2.2 & -6.1 & 1.9 & -7.2 \\
\hline AGR & -2.7 & -3.2 & -1.6 & -3.8 & -0.3 & -5.2 & -1.5 & -8.5 & 3.7 & -10.2 \\
\hline OTI & -4.5 & -6.1 & -2.7 & -4.6 & -4.0 & -6.3 & 1.2 & -3.7 & -1.1 & -6.3 \\
\hline PIP & -3.2 & -5.1 & -4.0 & -5.6 & -2.0 & -6.3 & -4.7 & -6.4 & -0.9 & -1.6 \\
\hline MWO & -10.6 & -0.3 & -2.6 & -7.2 & -9.2 & -5.6 & 9.5 & -3.5 & -2.2 & -12.2 \\
\hline MAR & -5.3 & -12.1 & -7.6 & -6.0 & -5.9 & -5.2 & -8.6 & -6.9 & -6.3 & -9.0 \\
\hline TRO & -6.6 & -11.0 & -7.9 & -2.7 & -15.1 & -2.7 & -18.5 & -2.3 & -10.0 & -1.2 \\
\hline CNM & -7.5 & -11.1 & -5.4 & -7.7 & -6.2 & -9.2 & -11.2 & -13.6 & 2.2 & -15.2 \\
\hline FIN & -8.8 & -8.8 & -8.5 & -9.7 & -8.0 & -9.8 & -7.2 & -9.0 & -9.3 & -8.5 \\
\hline FOO & -13.1 & -11.2 & -10.1 & -8.2 & -10.1 & -12.3 & -15.4 & -12.9 & 1.2 & -16.1 \\
\hline OTH & -8.1 & -14.3 & -9.3 & -13.9 & -7.0 & -15.6 & -6.2 & -17.9 & -4.8 & -21.9 \\
\hline GAS & & -16.0 & -9.6 & -14.1 & -12.4 & -15.0 & & & -0.9 & -22.7 \\
\hline
\end{tabular}

See Tables 1 and 2 for sector and regional market definitions.

Source: Authors' calculations. 
Table 17. Impact of WTO Accession on Unskilled Employment by Sector and Regional Market (percentage change)

\begin{tabular}{|c|c|c|c|c|c|c|c|c|c|c|}
\hline Good & Central & Siberia & South & North & Urals & Far East & Moscow & $\begin{array}{r}\text { St. } \\
\text { Peters. }\end{array}$ & Tumen & $\begin{array}{r}\text { North- } \\
\text { west } \\
\end{array}$ \\
\hline FME & 35.2 & 14.0 & 45.3 & 24.3 & 17.0 & 20.1 & 44.1 & 359.0 & & 12.5 \\
\hline $\mathrm{CHM}$ & 9.9 & 22.5 & 10.9 & -1.3 & 14.4 & 0.5 & 3.5 & 6.4 & 45.5 & 30.9 \\
\hline NFM & 12.9 & 5.4 & 34.6 & 11.1 & 24.8 & 6.6 & 36.3 & 1.7 & & -9.7 \\
\hline TMS & 10.7 & 5.8 & 9.4 & 17.3 & -0.9 & 17.3 & -3.9 & 17.4 & 11.5 & 18.7 \\
\hline TRK & 8.6 & 5.5 & 6.8 & 9.6 & 3.9 & 11.2 & 2.6 & 11.5 & 6.6 & 12.8 \\
\hline COL & 9.5 & 5.5 & 8.3 & 8.2 & 8.0 & 7.5 & & & & \\
\hline TRD & 6.6 & 4.1 & 3.7 & 3.4 & 5.1 & 4.1 & 4.4 & 6.8 & 1.7 & 8.8 \\
\hline OIL & 6.4 & -1.2 & 4.6 & 3.6 & 0.4 & 4.1 & 0.3 & -0.4 & 6.9 & \\
\hline $\mathrm{HOU}$ & 2.7 & 2.2 & 2.6 & 2.7 & 2.2 & 2.6 & 2.2 & 3.2 & 2.6 & 3.8 \\
\hline ELE & 3.5 & 2.4 & 2.3 & 1.6 & 3.0 & 1.1 & 0.8 & 3.4 & 0.4 & 5.9 \\
\hline RLW & 4.6 & 0.6 & 1.3 & 1.0 & 2.0 & 1.3 & -0.9 & 5.9 & 0.8 & 4.2 \\
\hline $\mathrm{SCl}$ & 0.0 & 1.5 & -0.1 & 3.0 & -0.5 & 3.7 & 0.0 & 5.4 & -0.7 & 5.3 \\
\hline HEA & 1.8 & 1.4 & 1.6 & 1.4 & 1.7 & 1.5 & 1.5 & 2.2 & 1.0 & 2.4 \\
\hline CON & 1.7 & -1.1 & 0.8 & -1.1 & 1.0 & -1.2 & 1.7 & -1.6 & 2.2 & -3.5 \\
\hline CRU & & -1.2 & 0.5 & -0.1 & 0.5 & -0.3 & & & 1.3 & -1.9 \\
\hline PST & 0.5 & -0.5 & -0.1 & -0.8 & 0.3 & -0.6 & -0.1 & -0.5 & -0.8 & 0.3 \\
\hline TPP & -6.0 & -4.2 & -10.0 & -0.4 & -1.3 & 30.1 & -13.0 & -8.0 & 15.1 & -9.5 \\
\hline AIR & -1.5 & -5.5 & -2.2 & 0.1 & -3.4 & -0.4 & -3.3 & -3.2 & 3.8 & -3.0 \\
\hline CLI & -1.0 & -4.1 & -1.8 & -2.8 & -2.4 & -2.6 & -3.4 & -5.4 & 1.5 & -6.2 \\
\hline AGR & -1.3 & -2.9 & -1.4 & -3.5 & 0.1 & -4.6 & -2.7 & -7.8 & 3.3 & -9.2 \\
\hline OTI & -3.2 & -5.9 & -2.5 & -4.4 & -3.6 & -5.8 & -0.1 & -3.0 & -1.5 & -5.3 \\
\hline PIP & -1.8 & -4.8 & -3.8 & -5.4 & -1.6 & -5.7 & -5.9 & -5.7 & -1.3 & -0.6 \\
\hline MWO & -9.3 & 0.0 & -2.4 & -7.0 & -8.9 & -5.0 & 8.2 & -2.8 & -2.6 & -11.3 \\
\hline MAR & -3.9 & -11.9 & -7.4 & -5.7 & -5.5 & -4.6 & -9.7 & -6.2 & -6.6 & -8.0 \\
\hline TRO & -5.3 & -10.8 & -7.7 & -2.5 & -14.7 & -2.1 & -19.5 & -1.5 & -10.4 & -0.1 \\
\hline CNM & -6.2 & -10.8 & -5.2 & -7.4 & -5.8 & -8.6 & -12.3 & -13.0 & 1.8 & -14.3 \\
\hline FIN & -7.5 & -8.5 & -8.3 & -9.5 & -7.6 & -9.3 & -8.3 & -8.4 & -9.7 & -7.5 \\
\hline FOO & -11.9 & -11.0 & -10.0 & -7.9 & -9.7 & -11.8 & -16.4 & -12.3 & 0.8 & -15.2 \\
\hline ОтН & -6.8 & -14.1 & -9.1 & -13.7 & -6.7 & -15.1 & -7.4 & -17.3 & -5.2 & -21.1 \\
\hline GAS & & -15.8 & -9.4 & -13.8 & -12.1 & -14.5 & & & -1.3 & -21.9 \\
\hline
\end{tabular}

See Tables 1 and 2 for sector and regional market definitions.

Source: Authors' calculations. 
Table 18. Impact of WTO Accession on Exports by Sector and Regional Market (percentage change)

\begin{tabular}{|c|c|c|c|c|c|c|c|c|c|c|}
\hline Good & Central & Siberia & South & North & Urals & Far East & Moscow & $\begin{array}{r}\text { St. } \\
\text { Peters. } \\
\end{array}$ & Tumen & $\begin{array}{r}\text { North- } \\
\text { west } \\
\end{array}$ \\
\hline FME & 61.0 & 30.1 & 76.6 & 49.7 & 34.2 & 45.1 & 70.2 & 423.5 & & 26.3 \\
\hline $\mathrm{CHM}$ & 31.6 & 39.8 & 35.4 & 18.7 & 32.1 & 21.0 & 23.2 & 21.8 & 82.8 & 44.2 \\
\hline $\mathrm{SCl}$ & 21.3 & 18.6 & 22.0 & 42.6 & 17.2 & 43.0 & 19.1 & 41.9 & 25.6 & 39.8 \\
\hline NFM & 21.2 & 11.3 & 47.7 & 19.3 & 34.0 & 14.6 & 48.3 & 3.2 & & -11.2 \\
\hline TMS & 14.9 & 5.8 & 13.8 & 28.0 & -0.3 & 27.0 & -4.3 & 21.0 & 20.9 & 20.4 \\
\hline CLI & 15.6 & 7.8 & 14.7 & 12.1 & 11.3 & 12.1 & 9.3 & 4.5 & 22.9 & 1.8 \\
\hline $\mathrm{COL}$ & 9.1 & 1.6 & 9.4 & 10.4 & 3.9 & 9.7 & & & & \\
\hline OIL & 9.4 & -1.6 & 9.0 & 7.3 & -0.4 & 8.1 & 2.2 & -1.1 & 13.0 & \\
\hline TRK & 7.0 & 1.5 & 5.8 & 6.5 & 2.4 & 7.5 & 2.6 & 4.7 & 8.5 & 4.4 \\
\hline FIN & 5.0 & 0.2 & 4.9 & 6.8 & 1.4 & 6.9 & 3.2 & 5.7 & 6.6 & 4.9 \\
\hline TPP & 0.9 & -4.8 & -2.0 & 6.0 & 0.9 & 36.1 & -6.6 & -5.2 & 28.2 & -10.2 \\
\hline MWO & -1.4 & 5.3 & 7.9 & 2.2 & -3.0 & 4.2 & 19.1 & 4.3 & 11.0 & -7.7 \\
\hline AGR & 6.5 & -3.3 & 7.2 & 4.2 & 1.0 & 3.4 & -0.6 & -4.7 & 16.8 & -9.5 \\
\hline CRU & & 1.6 & 2.4 & 2.9 & 1.3 & 2.1 & & & 2.9 & 1.3 \\
\hline OTI & 2.1 & -2.9 & 4.4 & 0.3 & 0.5 & -1.7 & 8.4 & 2.9 & 4.6 & -1.3 \\
\hline CNM & 3.5 & -6.6 & 6.5 & 3.1 & -1.6 & 2.2 & -5.3 & -7.1 & 17.9 & -11.4 \\
\hline PST & 2.6 & -1.7 & 2.9 & 1.1 & -0.7 & 0.7 & -2.1 & -5.0 & 7.1 & -5.8 \\
\hline AIR & 0.7 & -6.6 & 0.2 & 2.6 & -3.4 & 1.8 & -2.6 & -4.3 & 9.5 & -5.3 \\
\hline HEA & 0.9 & -2.9 & -0.2 & -3.0 & 0.2 & -3.0 & -0.2 & -3.8 & 1.3 & -5.2 \\
\hline CON & 0.9 & -3.8 & 1.1 & -3.0 & -0.2 & -3.3 & 3.7 & -6.4 & 4.7 & -9.8 \\
\hline ELE & -0.1 & -3.1 & 0.2 & -2.6 & -1.4 & -3.3 & -1.5 & -5.7 & 0.9 & -4.9 \\
\hline TRD & 0.9 & -3.8 & 0.0 & -2.9 & -2.3 & -2.0 & -2.8 & -6.2 & 1.9 & -6.5 \\
\hline FOO & -4.6 & -9.0 & -1.6 & -1.8 & -6.3 & -5.4 & -10.8 & -6.9 & 12.9 & -14.1 \\
\hline $\mathrm{HOU}$ & -3.6 & -5.7 & -2.4 & -5.2 & -4.1 & -5.5 & -2.9 & -9.6 & 0.4 & -10.6 \\
\hline RLW & -1.6 & -7.4 & -4.1 & -7.2 & -3.2 & -7.6 & -5.1 & -6.9 & -1.4 & -9.9 \\
\hline MAR & -3.6 & -14.7 & -6.2 & -4.5 & -7.1 & -3.6 & -9.1 & -8.5 & -3.4 & -11.7 \\
\hline TRO & -5.8 & -13.4 & -7.1 & -3.3 & -16.4 & -3.0 & -19.2 & -6.6 & -7.4 & -6.8 \\
\hline OTH & -6.2 & -17.2 & -8.8 & -15.8 & -6.3 & -18.5 & -7.0 & -22.7 & -1.9 & -27.5 \\
\hline GAS & & -40.8 & -17.0 & -33.2 & -31.6 & -33.9 & & & 2.3 & -71.2 \\
\hline PIP & & & & & & & & & & \\
\hline
\end{tabular}

See Tables 1 and 2 for sector and regional market definitions.

Source: Authors' calculations. 
Table 19. Piecemeal Sensitivity Analysis -- Welfare Impacts as a percent of GDP by Region ( $\%$ change from base year)

\begin{tabular}{|c|c|c|c|c|c|c|c|c|c|c|c|}
\hline Parameter being changed & \begin{tabular}{|r|}
$\begin{array}{r}\text { Overall } \\
\text { average }\end{array}$ \\
\end{tabular} & Moscow & $\begin{array}{r}\text { St. } \\
\text { Peters. }\end{array}$ & Tumen & $\begin{array}{r}\text { North- } \\
\text { west }\end{array}$ & North & Central & South & Urals & Siberia & $\begin{array}{l}\text { Far } \\
\text { East }\end{array}$ \\
\hline Central Results for reference & 4.3 & 4.7 & 5.7 & 3.1 & 6.2 & 4.7 & 4.2 & 4.7 & 3.3 & 4.2 & 5.2 \\
\hline regional investment potential variation ${ }^{\mathrm{a} /}$ & 4.2 & 5.1 & 6.0 & 3.3 & 5.6 & 4.0 & 3.8 & 4.2 & 3.2 & 3.6 & 4.6 \\
\hline esubconsumer $=1.5$ & 4.5 & 5.0 & 6.1 & 3.2 & 6.1 & 5.0 & 4.5 & 5.0 & 3.5 & 4.5 & 5.5 \\
\hline esubconsumer $=0.5$ & 4.1 & 4.5 & 5.4 & 3.0 & 5.9 & 4.1 & 4.0 & 4.5 & 3.1 & 4.0 & 4.9 \\
\hline esubs $=2.0$ & 5.5 & 5.9 & 7.3 & 4.3 & 7.2 & 6.1 & 5.5 & 6.0 & 4.3 & 5.4 & 6.6 \\
\hline esubs $=0.5$ & 3.5 & 4.0 & 4.8 & 2.4 & 5.2 & 2.4 & 3.6 & 3.9 & 2.6 & 3.5 & 3.9 \\
\hline sigmadm $=4$ & 4.3 & 4.8 & 5.8 & 3.2 & 6.3 & 4.8 & 4.2 & 4.8 & 3.3 & 4.3 & 5.2 \\
\hline sigmadm $=2$ & 4.3 & 4.7 & 5.7 & 3.1 & 6.2 & 4.7 & 4.2 & 4.7 & 3.3 & 4.2 & 5.2 \\
\hline etaf $=17.5$ & 4.8 & 5.2 & 6.1 & 3.5 & 6.7 & 5.2 & 4.7 & 5.3 & 3.8 & 4.8 & 5.6 \\
\hline etaf $=12.5$ & 3.7 & 4.2 & 5.2 & 2.7 & 5.6 & 3.9 & 3.6 & 4.1 & 2.7 & 3.6 & 4.6 \\
\hline etad $=10$ & 4.4 & 5.2 & 6.1 & 3.1 & 6.4 & 5.0 & 4.3 & 4.6 & 3.3 & 4.3 & 5.5 \\
\hline etad $=5$ & 4.0 & 4.1 & 5.1 & 3.1 & 6.0 & 4.3 & 4.1 & 4.5 & 3.3 & 4.1 & 4.7 \\
\hline esub $=4$ & 4.3 & 4.7 & 5.5 & 3.2 & 6.0 & 4.6 & 4.2 & 4.7 & 3.4 & 4.3 & 5.1 \\
\hline esub $=2$ & 4.3 & 4.7 & 5.5 & 3.2 & 6.0 & 4.6 & 4.2 & 4.7 & 3.4 & 4.3 & 5.1 \\
\hline esubprimary $=1.5$ & 4.3 & 4.7 & 5.7 & 3.1 & 6.3 & 4.7 & 4.3 & 4.7 & 3.4 & 4.2 & 5.1 \\
\hline esubprimary $=0.5$ & 4.3 & 4.9 & 5.7 & 3.1 & 5.9 & 4.8 & 4.0 & 4.8 & 3.1 & 4.2 & 5.4 \\
\hline etadx $=7$ & 4.3 & 4.8 & 5.8 & 3.0 & 6.3 & 4.7 & 4.3 & 4.8 & 3.3 & 4.2 & 5.2 \\
\hline etad $x=3$ & 4.3 & 4.6 & 5.6 & 3.3 & 6.1 & 4.7 & 4.2 & 4.7 & 3.3 & 4.2 & 5.1 \\
\hline
\end{tabular}

Source: Authors' calculations.

a/ We vary etaf by region as follows: Moscow = 20; St. Petersburg = 18.3; Tumen = 17.1; Northwest = 11.3; North = 10;

Central $=12.5 ;$ South $=11.5 ;$ Urals $=14.3 ;$ Siberia $=10.8 ;$ Far East $=10.8$.

\section{Notes:}

a. The piecemeal sensitivity analysis employs central values for all parameters (see below) other than the tested parameter and lump sum tax replacement.

b. Hicksian equivalent variation as a percent of the value of consumption in the benchmark equilibrium.

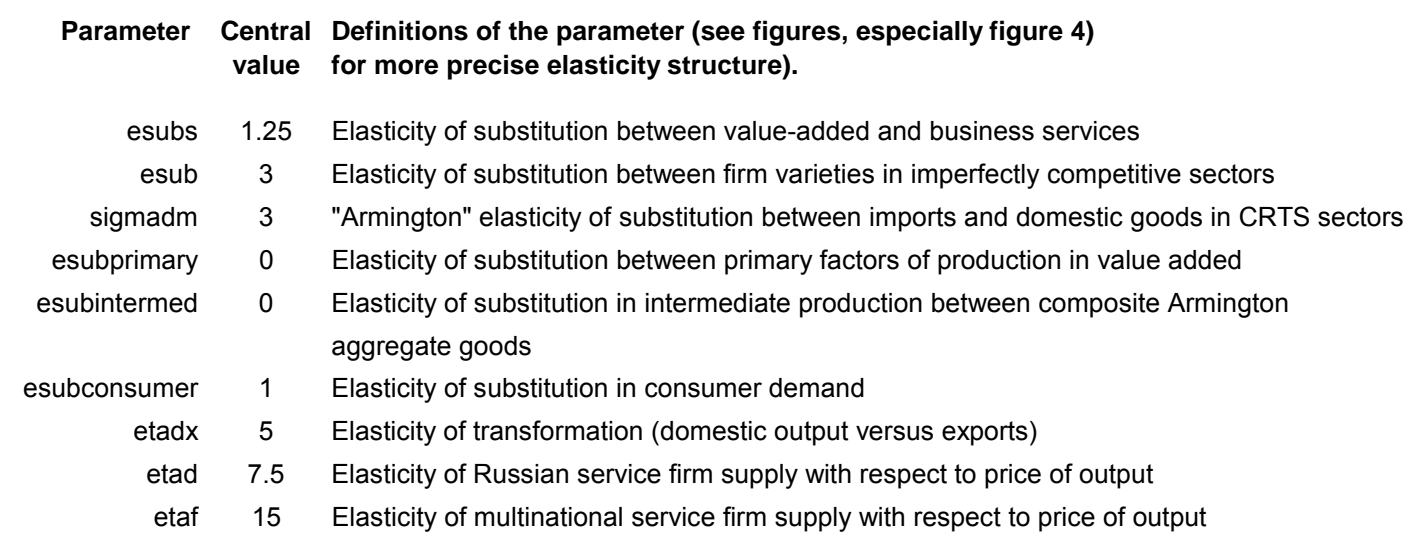


Figure 1. Sales for Constant Returns to Scale Sectors: Determined by Constant Elasticity of Transformation Production Structure

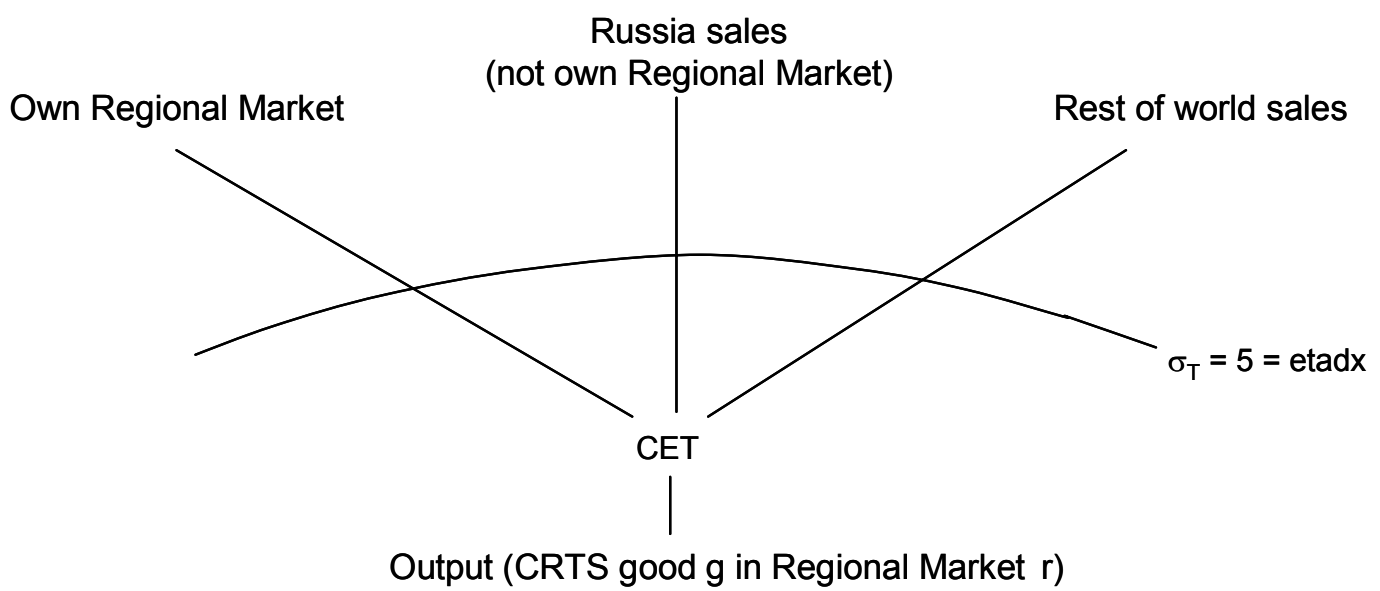


Figure 2. Demand for Representative CRTS good $\mathbf{g}$ in Regional Market $\mathbf{r}$

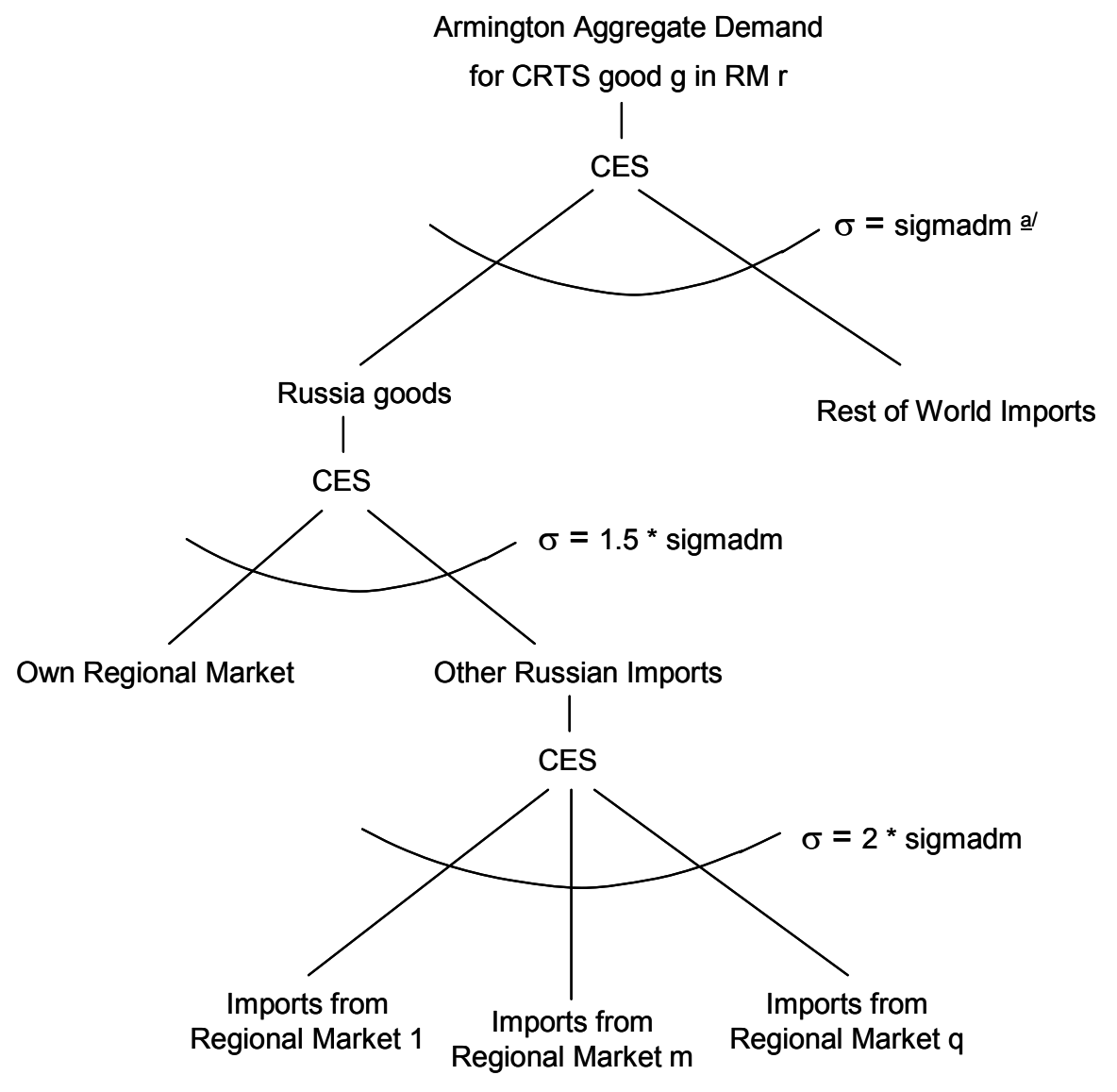

a/ sigmadm $=3$ in CRTS sectors, except in OTH (other goods producing sectors). For OTH we rely on estimates from Ivanova (2005). 
Figure 3. Demand for Representative Dixit-Stiglitz (IRTS) good $\mathbf{g}$ in Regional Market $r$

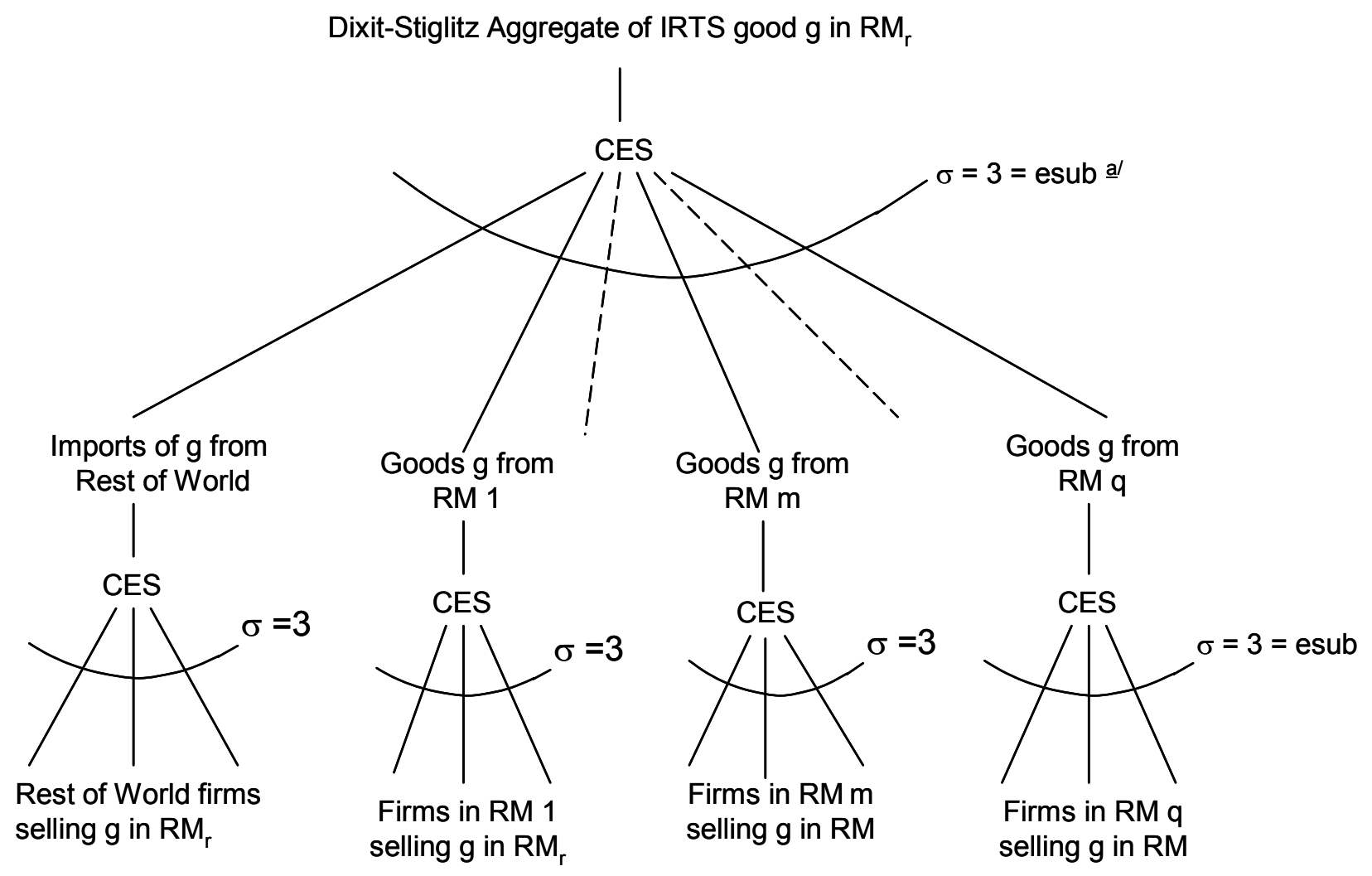

a/ We take $\sigma=3$, except based on Ivanova (2005), we take $\sigma=3.1$ in MWO; $\sigma=2.6$ in TPP; $\sigma=2.5$ in CNM; and $\sigma=1.8$ in OTI. 


\section{Figure 4. Structure of Production for Increasing Returns to Scale Russian Firms: \\ Representative Good or Service in a Representative Regional Market (RM) m}

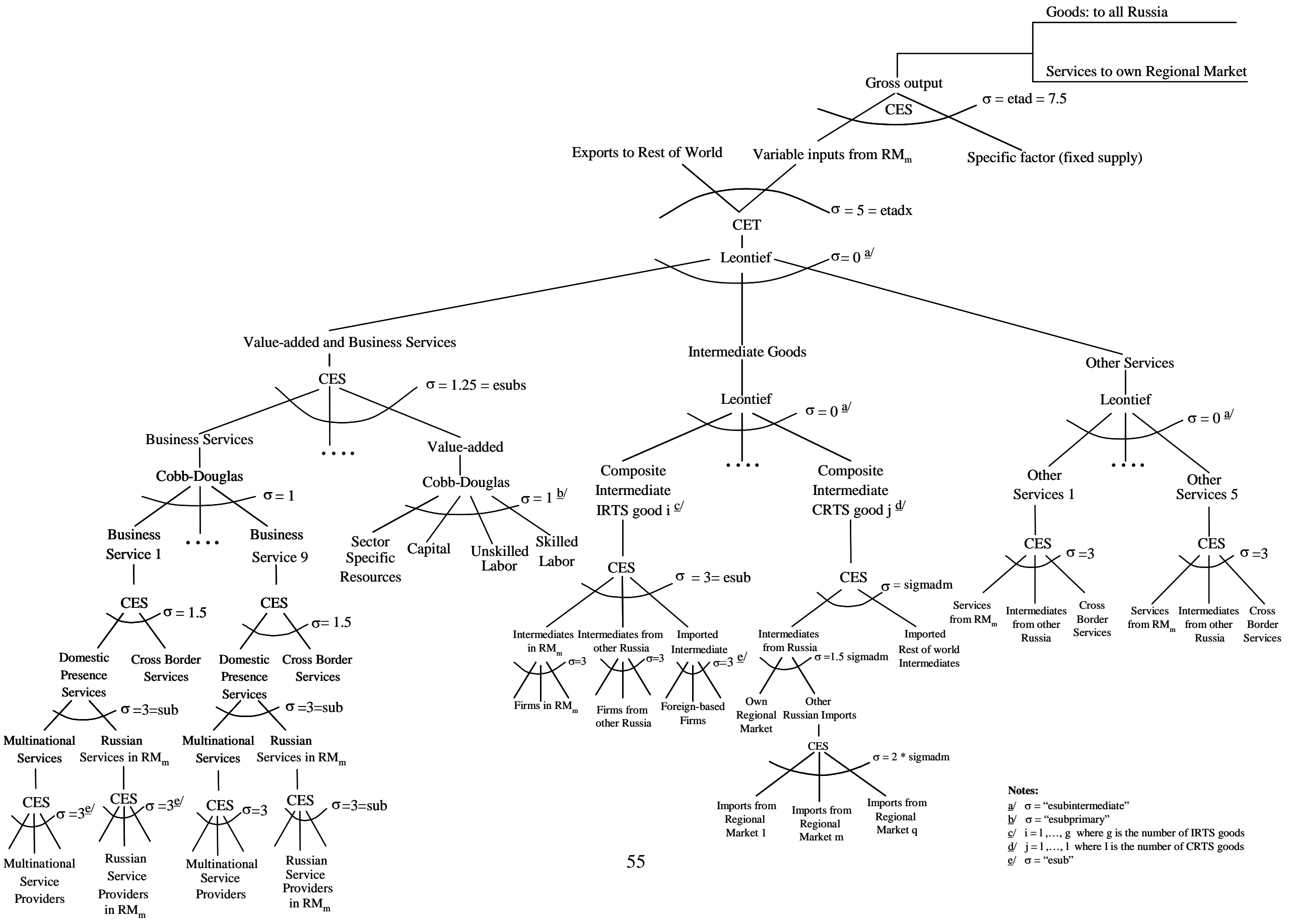


Figure 5. Demand for Representative Business Service $s$

(Dixit-Stiglitz) Sectors in Regional Market (RM) m

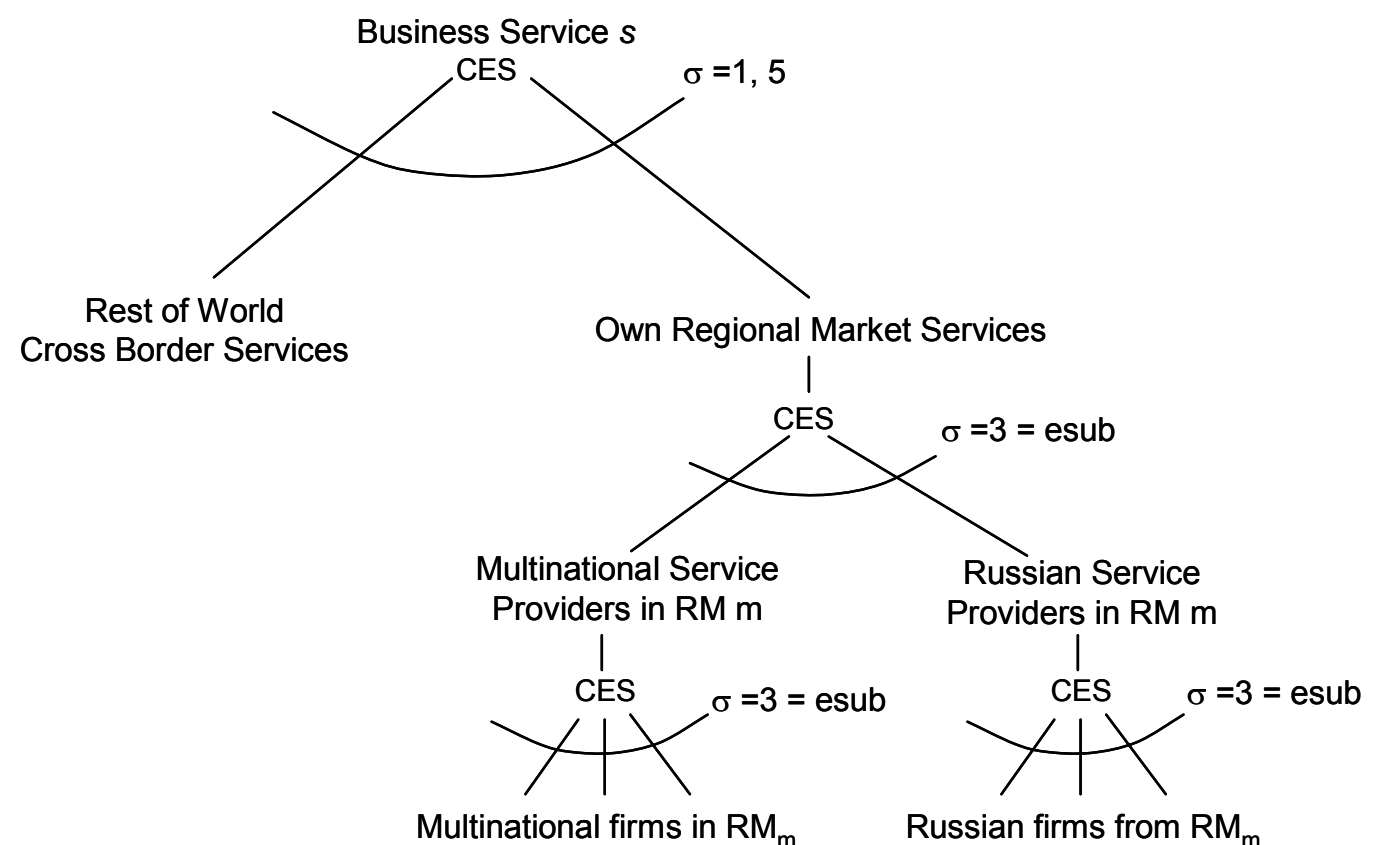


Figure 6. Structure of Production for Increasing Returns to Scale Multinational Business Service Firms: Representative Business Service in a Representative Regional Market (RM) m

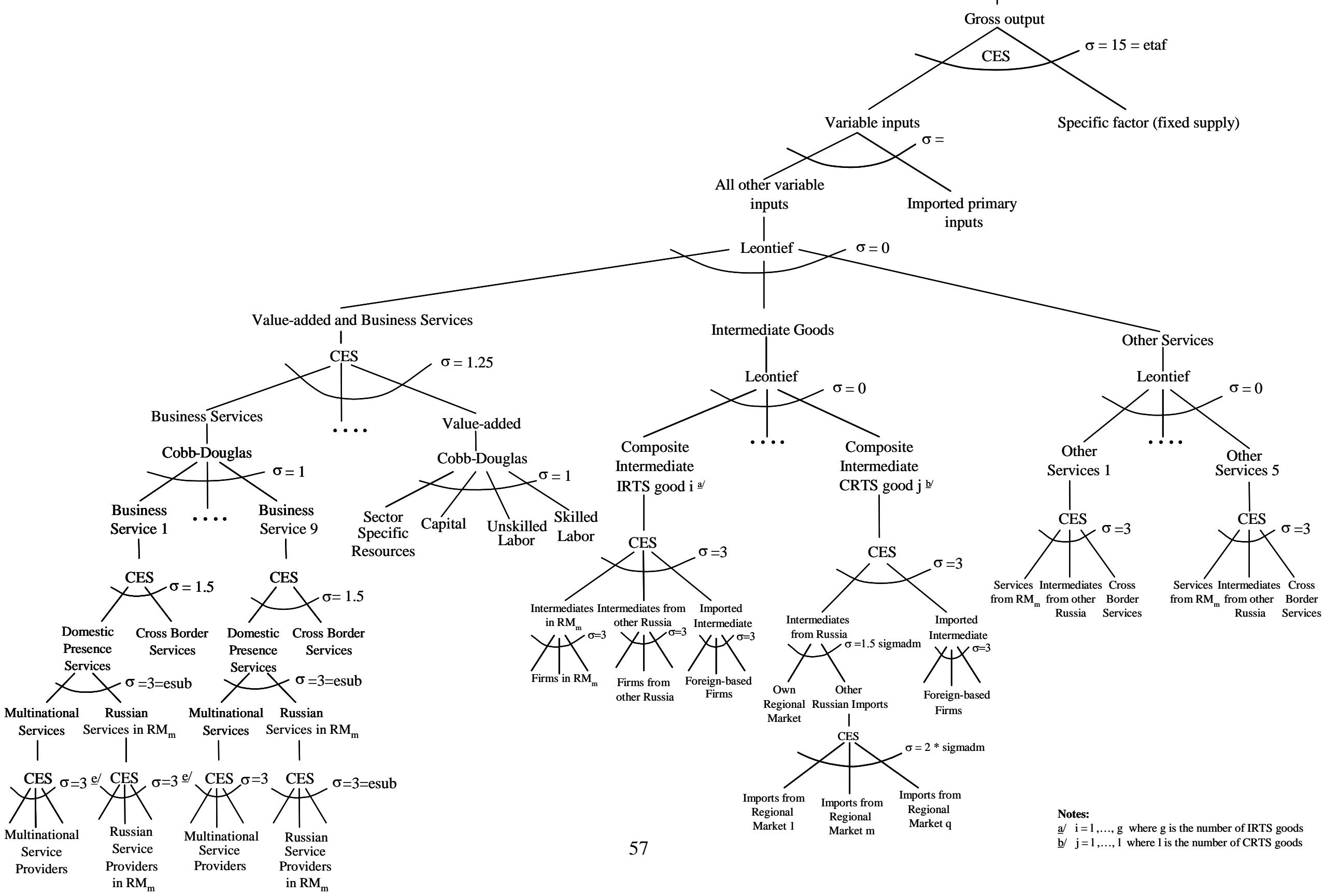




\section{Appendix A}

\section{Data on multinational shares of service sectors}

We consulted four sources of information: (1) estimates from Russian service sector institutes of the share by sector of multinational ownership in the key services sectors; (2) the NOBUS survey; (3) Regions of Russia (2003) by Rosstat; and (4) the "BEEPS survey. Of these four sources, only the NOBUS survey provides data that allows us to estimate shares of multinational ownership by both region and sector. We thus start with the NOBUS information (our results by region and service sector are summarized in table A4 below).

When we aggregate the NOBUS shares across regions or sectors, however, we find that the other three sources of information, show considerably higher foreign ownership shares than the NOBUS survey. We believe that the NOBUS survey estimates are too small, and adjust them. The estimates of the service sectors institutes are lower than those from the BEEPS or Regions of Russia, and thus involve less adjustment of the NOBUS data. We employed least squares adjustment of the NOBUS data so that the weighted average over all of Russia in each sector is consistent with the national estimates we received from the specialist service sector research institutes in Russia. This process will give as a structure of ownership based on the NOBUS survey, with the economy-wide average by sector determined by the national data. The results are in table 12b. In this appendix we explain the details of how we obtained the and calculated the data.

\section{Data}

We use three sources of data to calculate regional shares of output produced by multinational companies by regions and sectors, and we combine this with our national estimates from our Russian service sector experts. The regional data are:

1.1 The National Survey of Household Welfare and Program Participation (NOBUS) that was implemented in 87 "oblasts" of the Russian Federation in 2003 by means of random sampling procedures. The survey was conducted on the basis of voluntary participation of selected households. The households that refused to participate in the survey were replaced by the households from the same voting district. Total number of households that agreed to participate in the survey is 44,529 . 
1.2 The Statistical handbook "Regions of Russia: Social and economic indicators: 2003" published by Roskomstat. The handbook contains the major economic and social statistical indicators for Russia since 1990 by economic region.

1.3 Business Environment and Enterprise Performance Survey (BEEPS) 2002 developed jointly by the World Bank and the European Bank for Reconstruction and Development. BEEPS is a survey of managers and owners of 6,636 firms across the countries of Eastern Europe, the former Soviet Union, and Turkey.

\section{Calculations}

2.1. NOBUS. Respondents in the NOBUS survey report their wage income, the industry in which they work and whether the company is Russian owned, foreign owned or mixed ownership. For each region and industry we calculate the share of wage income earned in foreign or mixed ownership companies compared with the share of wage income earned in Russian companies. We take this wage share (in foreign plus mixed ownership companies) as a proxy for the share of output in each region and industry. Documentation of the details follows.

\subsubsection{Variables}

First, we define a variable industry $i$ based on the Question 17, Part C of the survey ${ }^{24}$. We assign a three letter code according to the Table A1

Table A1 Mapping of the survey Question 9, part C into IO table sector code

\begin{tabular}{lllc}
\hline Industry & Code & I O table code & Question 9, Part C \\
\hline Agriculture \& forestry and food & AGF & AGF, FOO & 1,2 \\
Mining & MIN & FME NFM COA OLE & 3 \\
Manufacturing & MNF & MWO TPP CNM CLO OTHT OIN & 4 \\
Electric industry & ELE & ELE & 5 \\
Construction & CON & CON & 6 \\
Trade & TRD & TRD & 7 \\
Catering & CAT & CAT & 8 \\
Communication and transport & COM & RLW TRK PIP MAR AIR TRO & 9 \\
& & TMS PST & \\
Financial services & FIN & FIN & 10 \\
Communal \& consumer services & PSM & PSM & 15,16 \\
Administration \& public & ADM & ADM & 12,17 \\
associations & & & 13 \\
Education \& culture \& art & ECM & ECM & 11 \\
Science \& science servicing & SCS & SCS & 14 \\
Public health \& sports \& social & SSM & SSM & \\
security & & & \\
\hline
\end{tabular}

\footnotetext{
${ }^{24}$ Industries are encoded using a 2-digit code from the list of economic activity classification groups given in the Questionnaire form and based on National Classifier of Economic Activities OK 029-2001 (OKVED).
} 
Second, we define a region code $\mathrm{j}$ as shown in the Table 2.

Third, we define a variable ownership based on the Question 9, Part C of the survey. For each respondent $\mathrm{k}$ who worked during the sample period ${ }^{25}$, we define ownership as foreign if the respondent answered that she worked at the enterprise with mixed (both Russian and foreign) ownership, or with foreign ownership. Otherwise, we define ownership as local.

Finally, for each respondent $\mathrm{k}$ who worked during the sample period, we define a variable wage according to the respondent's answer to the Question 13, Part C of the survey: what was your wage in rubles in the last 30 days?

\subsubsection{Aggregation}

\section{All regions}

We replicate observations according to the weight $\mathbf{k v z v}_{\mathbf{i j k}}$ that is assigned to each respondent and aggregate the variable wage $_{i j k}$ by regions and industries according to the type of ownership:

$$
\begin{aligned}
& \text { foreign }_{i j}=\sum_{k \in \text { foreign }} k v z v_{i j k} * \text { wage }_{i j k} \\
& \text { local }_{i j}=\sum_{k \in \text { local }} k v z v_{i j k} * w_{\text {age }}{ }_{i j k}
\end{aligned}
$$

$\mathrm{i}$ is an industry code as defined in the second column of the Table 1

$\mathrm{j}$ is a region as defined in the Table 2

and calculate a share of foreign owned enterprises calculated as

$$
\text { foreign_share }_{i j}=\frac{\text { foreign }_{i j}}{\text { foreign }_{i j}+\text { local }_{i j}}
$$

The results are presented in the Table A2.

\footnotetext{
${ }^{25}$ A respondent worked during the investigated period if she answered "Yes" to the Question 1 or the Question 2, Part C of the survey.
} 
Table A2 Share of foreign owned companies

\begin{tabular}{|c|c|c|c|c|c|c|c|c|c|c|c|c|c|c|}
\hline Region & $A D M$ & AGF & $C A T$ & COM $^{*}$ & CON & $E C M$ & $E L E$ & FIN & $M I N^{* *}$ & $M N F^{\star \star *}$ & $P S M$ & SCS & SSM & TRD \\
\hline alt & 0.00 & 0.00 & & 0.00 & 0.00 & 0.00 & 0.00 & 0.00 & & 0.00 & 0.00 & 0.00 & 0.00 & 0.13 \\
\hline$a m u$ & 0.00 & 0.00 & 0.00 & 0.00 & 0.05 & 0.00 & 0.00 & 0.00 & 0.00 & 0.04 & 0.00 & 0.00 & 0.00 & 0.00 \\
\hline arh & 0.00 & 0.01 & 0.00 & 0.01 & 0.01 & 0.00 & 0.00 & 0.00 & 0.00 & 0.08 & 0.00 & 0.00 & 0.00 & 0.00 \\
\hline ast & 0.00 & 0.00 & 0.00 & 0.02 & 0.00 & 0.00 & 0.00 & 0.00 & 0.03 & 0.34 & 0.00 & 0.00 & 0.01 & 0.00 \\
\hline bel & 0.00 & 0.00 & 0.00 & 0.00 & 0.00 & 0.00 & 0.00 & 0.00 & 0.00 & 0.00 & 0.00 & & 0.00 & 0.00 \\
\hline bry & 0.00 & 0.00 & 0.00 & 0.02 & 0.00 & 0.00 & 0.00 & 0.00 & 0.00 & 0.00 & 0.00 & 0.00 & 0.00 & 0.00 \\
\hline vla & 0.00 & 0.00 & & 0.00 & 0.00 & 0.00 & 0.00 & & 0.00 & 0.08 & 0.00 & 0.00 & 0.00 & 0.00 \\
\hline vlg & 0.00 & 0.01 & 0.00 & 0.00 & 0.00 & 0.00 & 0.08 & 0.00 & 0.13 & 0.01 & 0.00 & 0.00 & 0.00 & 0.00 \\
\hline vol & 0.00 & 0.00 & 0.00 & 0.00 & 0.00 & 0.00 & 0.00 & 0.00 & & 0.00 & 0.00 & & 0.00 & 0.00 \\
\hline vor & 0.00 & 0.00 & 0.00 & 0.00 & 0.00 & 0.00 & 0.00 & 0.00 & 0.00 & 0.05 & 0.00 & 0.00 & 0.00 & 0.01 \\
\hline msk & 0.00 & 0.00 & 0.00 & 0.00 & 0.00 & 0.00 & 0.00 & 0.12 & 0.33 & 0.00 & 0.00 & 0.03 & 0.00 & 0.01 \\
\hline spb & 0.04 & 0.00 & 0.00 & 0.01 & 0.01 & 0.00 & 0.00 & 0.00 & 0.25 & 0.06 & 0.00 & 0.03 & 0.00 & 0.03 \\
\hline eao & 0.00 & 0.00 & 0.00 & 0.00 & 0.00 & 0.00 & 0.00 & 0.00 & 0.00 & 0.00 & 0.00 & 0.00 & 0.00 & 0.00 \\
\hline iva & 0.00 & 0.00 & 0.00 & 0.01 & 0.00 & 0.00 & 0.00 & 0.00 & 0.00 & 0.00 & 0.00 & 0.00 & 0.00 & 0.00 \\
\hline irk & 0.00 & 0.00 & 0.00 & 0.00 & 0.00 & 0.00 & 0.00 & 0.00 & 0.00 & 0.38 & 0.00 & 0.00 & 0.00 & 0.00 \\
\hline kab & 0.00 & 0.00 & 0.00 & 0.00 & 0.00 & 0.00 & 0.00 & 0.00 & 0.00 & 0.00 & 0.00 & 0.00 & 0.00 & 0.00 \\
\hline klg & 0.00 & 0.00 & 0.00 & 0.00 & 0.00 & 0.10 & 0.00 & 0.00 & 0.00 & 0.00 & 0.24 & 0.00 & 0.00 & 0.03 \\
\hline kal & 0.00 & 0.00 & 0.00 & 0.00 & 0.00 & 0.00 & 0.00 & & 0.00 & 0.00 & 0.00 & 0.00 & 0.00 & 0.00 \\
\hline kam & 0.00 & 0.01 & 0.00 & 0.00 & 0.00 & 0.00 & 0.03 & 0.00 & 0.00 & 0.16 & 0.00 & 0.00 & 0.00 & 0.00 \\
\hline kar & 0.00 & 0.00 & & 0.00 & 0.00 & 0.00 & 0.00 & & 0.00 & 0.00 & 0.00 & 0.00 & 0.00 & 0.00 \\
\hline kem & 0.00 & 0.00 & 0.00 & 0.00 & 0.00 & 0.00 & 0.00 & 0.00 & 0.02 & 0.00 & 0.00 & 0.00 & 0.00 & 0.00 \\
\hline kir & 0.00 & 0.00 & 0.00 & 0.00 & 0.00 & 0.00 & 0.02 & 0.00 & 0.00 & 0.03 & 0.00 & 0.00 & 0.00 & 0.00 \\
\hline kos & 0.00 & 0.00 & 0.00 & 0.00 & 0.05 & 0.00 & 0.00 & 0.06 & 0.00 & 0.04 & 0.00 & 0.00 & 0.00 & 0.00 \\
\hline$k d k$ & 0.00 & 0.00 & 0.00 & 0.02 & 0.07 & 0.00 & 0.00 & 0.00 & 0.00 & 0.05 & 0.00 & 0.00 & 0.01 & 0.00 \\
\hline kra & 0.00 & 0.00 & 0.15 & 0.00 & 0.01 & 0.00 & 0.02 & 0.00 & 0.02 & 0.06 & 0.00 & 0.00 & 0.00 & 0.00 \\
\hline krg & 0.00 & 0.00 & 0.00 & 0.00 & 0.00 & 0.00 & 0.00 & 0.00 & 0.00 & 0.00 & 0.00 & 0.00 & 0.00 & 0.00 \\
\hline krs & 0.00 & 0.00 & & 0.00 & 0.00 & 0.00 & 0.00 & 0.00 & 0.00 & 0.00 & 0.00 & 0.00 & 0.00 & 0.00 \\
\hline len & 0.00 & 0.10 & 0.24 & 0.09 & 0.00 & 0.00 & 0.00 & 0.00 & 0.00 & 0.07 & 0.00 & 0.00 & 0.00 & 0.00 \\
\hline lip & 0.00 & 0.00 & 0.00 & 0.03 & 0.00 & 0.00 & 0.00 & 0.00 & 0.00 & 0.10 & 0.00 & 0.00 & 0.00 & 0.00 \\
\hline mag & 0.00 & 0.00 & 0.00 & 0.00 & 0.00 & 0.00 & 0.00 & & 0.00 & 0.00 & 0.00 & 0.00 & 0.00 & 0.00 \\
\hline mos & 0.00 & 0.00 & 0.00 & 0.00 & 0.00 & 0.00 & 0.00 & 0.00 & 0.00 & 0.00 & 0.00 & 0.00 & 0.00 & 0.00 \\
\hline mur & 0.01 & 0.04 & 0.00 & 0.00 & 0.00 & 0.00 & 0.00 & 0.00 & 0.00 & 0.10 & 0.00 & 0.00 & 0.00 & 0.00 \\
\hline niz & 0.00 & 0.00 & 0.11 & 0.01 & 0.00 & 0.00 & 0.00 & 0.00 & 0.00 & 0.01 & 0.02 & 0.00 & 0.01 & 0.00 \\
\hline nov & 0.00 & 0.00 & 0.00 & 0.00 & 0.00 & 0.00 & 0.00 & 0.00 & 0.00 & 0.12 & 0.00 & 0.54 & 0.00 & 0.00 \\
\hline$n v s$ & 0.00 & 0.00 & 0.00 & 0.00 & 0.05 & 0.00 & 0.00 & 0.00 & 0.00 & 0.00 & 0.00 & 0.06 & 0.00 & 0.00 \\
\hline
\end{tabular}




\begin{tabular}{|c|c|c|c|c|c|c|c|c|c|c|c|c|c|c|}
\hline Region & $A D M$ & AGF & CAT & COM $^{*}$ & CON & $E C M$ & $E L E$ & FIN & $M I N^{* *}$ & $M N F^{* \star *}$ & $P S M$ & SCS & SSM & TRD \\
\hline oms & 0.00 & 0.00 & 0.00 & 0.00 & 0.00 & 0.00 & 0.00 & 0.00 & 0.00 & 0.00 & 0.00 & 0.00 & 0.00 & 0.00 \\
\hline ore & 0.00 & 0.00 & 0.00 & 0.00 & 0.00 & 0.00 & & 0.00 & 0.00 & 0.02 & 0.00 & 0.00 & 0.00 & 0.00 \\
\hline orl & 0.00 & 0.00 & 0.00 & 0.00 & 0.00 & 0.00 & 0.31 & 0.00 & 0.00 & 0.02 & 0.00 & 0.00 & 0.00 & 0.01 \\
\hline pen & 0.00 & 0.00 & 0.00 & 0.00 & 0.00 & 0.00 & 0.00 & 0.00 & & 0.05 & 0.00 & 0.00 & 0.00 & 0.00 \\
\hline per & 0.00 & 0.00 & 0.00 & 0.00 & 0.00 & 0.00 & 0.00 & 0.00 & 0.00 & 0.00 & 0.00 & 0.00 & 0.00 & 0.00 \\
\hline pri & 0.00 & 0.19 & 0.31 & 0.05 & 0.00 & 0.00 & 0.02 & 0.00 & 0.00 & 0.09 & 0.01 & 0.00 & 0.00 & 0.02 \\
\hline psk & 0.00 & 0.05 & 0.00 & 0.00 & 0.00 & 0.00 & 0.00 & 0.00 & 0.00 & 0.00 & 0.14 & 0.17 & 0.00 & 0.00 \\
\hline sev & 0.00 & 0.00 & & 0.00 & 0.00 & 0.00 & 0.00 & 0.00 & 0.00 & 0.00 & 0.00 & 0.00 & 0.00 & 0.00 \\
\hline ady & 0.00 & 0.00 & 0.00 & 0.00 & 0.00 & 0.00 & 0.00 & 0.00 & 0.00 & 0.00 & 0.00 & 0.00 & 0.00 & 0.00 \\
\hline alr & 0.00 & 0.02 & 0.00 & 0.00 & 0.00 & 0.00 & 0.00 & 0.00 & & 0.00 & 0.00 & 0.00 & 0.00 & 0.00 \\
\hline bas & 0.00 & 0.00 & 0.00 & 0.00 & 0.00 & 0.00 & 0.00 & 0.00 & 0.03 & 0.01 & 0.00 & 0.00 & 0.00 & 0.00 \\
\hline bur & 0.00 & 0.00 & 0.00 & 0.00 & 0.01 & 0.00 & 0.00 & 0.00 & 0.08 & 0.08 & 0.00 & 0.00 & 0.00 & 0.00 \\
\hline dag & 0.00 & 0.00 & 0.00 & 0.07 & 0.00 & 0.00 & 0.00 & 0.00 & 0.00 & 0.03 & 0.00 & 0.00 & 0.00 & 0.00 \\
\hline ing & 0.00 & 0.00 & & 0.00 & 0.00 & 0.23 & 0.00 & & & 0.00 & 0.00 & 0.00 & 0.00 & 0.00 \\
\hline$k l r$ & 0.00 & 0.00 & & 0.00 & 0.00 & 0.00 & 0.00 & & & 0.00 & 0.00 & 0.00 & 0.00 & 0.00 \\
\hline$k r l$ & 0.00 & 0.50 & 0.00 & 0.00 & 0.00 & 0.00 & & 0.00 & 0.00 & 0.00 & 0.00 & 0.00 & 0.00 & 0.00 \\
\hline kom & 0.00 & 0.05 & 0.00 & 0.00 & 0.00 & 0.00 & 0.00 & 0.00 & 0.05 & 0.00 & 0.00 & 0.00 & 0.00 & 0.01 \\
\hline mar & 0.00 & 0.00 & & 0.00 & 0.00 & 0.00 & 0.00 & 0.00 & & 0.00 & 0.00 & 0.00 & 0.00 & 0.00 \\
\hline mor & 0.00 & 0.00 & 0.00 & 0.00 & 0.00 & 0.00 & 0.00 & 0.00 & 0.00 & 0.00 & 0.00 & 0.00 & 0.00 & 0.00 \\
\hline sah & 0.00 & 0.00 & 0.00 & 0.00 & 0.00 & 0.00 & 0.00 & 0.00 & 0.05 & 0.00 & 0.00 & 0.00 & 0.00 & 0.03 \\
\hline tat & 0.00 & 0.00 & 0.00 & 0.00 & 0.00 & 0.00 & 0.00 & 0.00 & 0.00 & 0.00 & 0.00 & 0.21 & 0.00 & 0.03 \\
\hline tyv & 0.00 & 0.00 & & 0.00 & & 0.00 & 0.00 & 0.00 & 0.00 & & 0.00 & & 0.00 & 0.00 \\
\hline hak & 0.00 & 0.00 & & 0.00 & 0.00 & 0.00 & 0.00 & & 0.00 & 0.00 & 0.00 & & 0.00 & 0.00 \\
\hline ros & 0.00 & 0.00 & 0.00 & 0.00 & 0.00 & 0.02 & 0.00 & 0.00 & 0.00 & 0.01 & 0.00 & 0.00 & 0.00 & 0.00 \\
\hline rya & 0.00 & 0.00 & & 0.00 & 0.00 & 0.00 & 0.00 & 0.00 & 0.00 & 0.00 & 0.00 & 0.00 & 0.00 & 0.00 \\
\hline sam & 0.00 & 0.00 & 0.00 & 0.03 & 0.00 & 0.00 & 0.00 & 0.00 & 0.00 & 0.06 & 0.00 & 0.00 & 0.02 & 0.02 \\
\hline sar & 0.00 & 0.00 & & 0.00 & 0.00 & 0.00 & 0.00 & & 0.00 & 0.00 & 0.00 & 0.00 & 0.00 & 0.00 \\
\hline sao & 0.00 & 0.02 & 0.00 & 0.03 & 0.00 & 0.01 & 0.02 & 0.00 & 0.38 & 0.00 & 0.01 & 0.11 & 0.00 & 0.00 \\
\hline sve & 0.00 & 0.00 & 0.00 & 0.00 & 0.00 & 0.00 & 0.00 & 0.00 & 0.01 & 0.03 & 0.00 & 0.00 & 0.00 & 0.00 \\
\hline smo & 0.00 & 0.00 & & 0.00 & 0.00 & 0.00 & 0.00 & & 0.00 & 0.00 & 0.00 & & 0.00 & 0.00 \\
\hline sta & 0.00 & 0.00 & & 0.00 & 0.00 & 0.00 & 0.00 & 0.00 & & 0.00 & 0.00 & & 0.00 & 0.00 \\
\hline tam & 0.00 & 0.00 & 0.00 & 0.00 & 0.00 & 0.00 & 0.00 & 0.00 & 0.00 & 0.00 & 0.00 & 0.00 & 0.00 & 0.00 \\
\hline tve & 0.00 & 0.00 & 0.00 & 0.00 & 0.01 & 0.00 & 0.00 & 0.00 & 0.00 & 0.00 & 0.00 & 0.00 & 0.00 & 0.01 \\
\hline tom & 0.00 & 0.00 & & 0.00 & 0.00 & 0.00 & 0.00 & 0.00 & 0.00 & 0.00 & 0.00 & 0.00 & 0.00 & 0.00 \\
\hline tul & 0.00 & 0.00 & 0.00 & 0.00 & 0.00 & 0.00 & 0.00 & 0.00 & 0.00 & 0.03 & 0.00 & & 0.00 & 0.00 \\
\hline tum & 0.00 & 0.00 & 0.00 & 0.00 & 0.01 & 0.00 & 0.00 & 0.00 & 0.03 & 0.02 & 0.00 & 0.04 & 0.00 & 0.00 \\
\hline
\end{tabular}




\begin{tabular}{lrccccccccccccc}
\hline Region & ADM & AGF & CAT & COM $^{*}$ & CON & ECM & ELE & FIN & MIN $^{* *}$ & MNF $^{* * *}$ & PSM & SCS & SSM & TRD \\
\hline udm & 0.00 & 0.00 & 0.00 & 0.00 & 0.00 & 0.00 & 0.00 & 0.00 & 0.22 & 0.00 & 0.00 & 0.00 & 0.00 & 0.00 \\
ulo & 0.00 & 0.00 & & 0.00 & 0.00 & 0.00 & 0.00 & 0.00 & 0.00 & 0.00 & 0.00 & 0.00 & 0.00 & 0.00 \\
hab & 0.00 & 0.15 & 0.00 & 0.01 & 0.00 & 0.00 & 0.00 & 0.00 & 0.00 & 0.01 & 0.00 & 0.00 & 0.00 & 0.01 \\
chl & 0.00 & 0.09 & 0.00 & 0.02 & 0.00 & 0.00 & 0.00 & 0.00 & 0.15 & 0.23 & 0.00 & 0.00 & 0.00 & 0.00 \\
chi & 0.00 & 0.00 & 0.00 & 0.00 & 0.00 & 0.00 & 0.00 & 0.00 & 0.12 & 0.02 & 0.00 & 0.00 & 0.00 & 0.00 \\
chv & 0.00 & 0.00 & 0.00 & 0.00 & 0.00 & 0.00 & 0.00 & 0.00 & 0.00 & 0.08 & 0.00 & 0.00 & 0.00 & 0.00 \\
chu & 0.00 & 0.00 & 0.00 & 0.00 & 0.51 & 0.00 & 0.06 & 0.00 & 0.00 & & 0.00 & 0.00 & 0.00 & 0.00 \\
yar & 0.00 & 0.00 & 0.00 & 0.00 & 0.01 & 0.00 & 0.00 & 0.00 & 0.00 & 0.01 & 0.00 & 0.00 & 0.00 & 0.00 \\
\hline
\end{tabular}

* $\quad$ COM (communication and transport) includes RLW TRK PIP MAR AIR TRO TMS PST

** $\quad$ MIN(mining) includes FME NFM COA OLE

*** MNF (manufacturing) includes MWO TPP CNM CLO OTHT OIN

Source: NOBUS 2003 


\section{0 bigger regions}

Table A3 presents shares of foreign owned enterprises for 10 bigger regions: Moscow, Saint

Petersburg, Tumen, Northwest, North, Center, South, Ural, Siberia, and Far East regions.

Aggregation from the regional level to the 10 big regions is conducted according to the following

formula:

$$
\text { foreign_share }_{k j}=\frac{\sum_{i \in k} \text { foreign }_{i j}}{\sum_{i \in k} \text { foreign }_{i j}+\text { local }_{i j}}
$$

where $\mathrm{i}$ is a region that belongs to a bigger region $\mathrm{k}$.

Table A3 Share of foreign owned companies for 10 regions

\begin{tabular}{|c|c|c|c|c|c|c|c|c|c|c|c|c|c|c|}
\hline & $A D M$ & AGF & $C A T$ & $\mathrm{COM}^{*}$ & CON & $E C M$ & ELE & FIN & $M I N^{* *}$ & $M N F^{* * *}$ & PSM & scs & SSM & TRD \\
\hline $\begin{array}{l}\text { Moscow } \\
\text { Saint }\end{array}$ & 0.000 & 0.000 & 0.000 & 0.001 & 0.000 & 0.000 & 0.000 & 0.101 & 0.222 & 0.000 & 0.000 & 0.025 & 0.000 & 0.009 \\
\hline Petersburgh & 0.021 & 0.082 & 0.042 & 0.032 & 0.006 & 0.000 & 0.000 & 0.000 & 0.111 & 0.060 & 0.000 & 0.023 & 0.000 & 0.030 \\
\hline Tumen & 0.000 & 0.000 & 0.000 & 0.000 & 0.008 & 0.000 & 0.000 & 0.000 & 0.028 & 0.021 & 0.000 & 0.037 & 0.000 & 0.000 \\
\hline Northwest & 0.000 & 0.004 & 0.000 & 0.000 & 0.000 & 0.040 & 0.000 & 0.000 & 0.000 & 0.024 & 0.086 & 0.192 & 0.000 & 0.010 \\
\hline North & 0.006 & 0.115 & 0.000 & 0.003 & 0.002 & 0.000 & 0.000 & 0.000 & 0.025 & 0.044 & 0.000 & 0.000 & 0.000 & 0.004 \\
\hline Center & 0.000 & 0.000 & 0.000 & 0.003 & 0.005 & 0.000 & 0.005 & 0.003 & 0.000 & 0.026 & 0.000 & 0.000 & 0.000 & 0.003 \\
\hline South & 0.000 & 0.000 & 0.000 & 0.006 & 0.023 & 0.006 & 0.013 & 0.000 & 0.023 & 0.024 & 0.000 & 0.000 & 0.004 & 0.000 \\
\hline Urals & 0.000 & 0.005 & 0.016 & 0.005 & 0.000 & 0.000 & 0.001 & 0.000 & 0.034 & 0.046 & 0.002 & 0.035 & 0.003 & 0.005 \\
\hline Sibiria & 0.000 & 0.001 & 0.069 & 0.000 & 0.010 & 0.000 & 0.005 & 0.000 & 0.021 & 0.141 & 0.000 & 0.013 & 0.000 & 0.013 \\
\hline Far East & 0.000 & 0.121 & 0.077 & 0.018 & 0.006 & 0.001 & 0.008 & 0.000 & 0.096 & 0.046 & 0.004 & 0.012 & 0.000 & 0.010 \\
\hline * & & & & & & & & & & & & & & \\
\hline ** & & & & & & LEE & & & & & & & & \\
\hline *** & MNF & 11140 & & & & 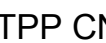 & & & & & & & & \\
\hline
\end{tabular}

\section{$2.2 \quad$ Regions of Russia 2003}

Table 3.5 of "Regions of Russia 2003" reports the distribution of labor force by regions and types of ownership in 2002. The types of ownership include state, city, private, NGO, mixed Russian $^{26}$, and foreign ${ }^{27}$ ownership. Unfortunately, the handbook does not have the sectoral distribution of labor by the types of ownership within a region. Therefore, we can calculate only the regional distribution of workers.

\footnotetext{
${ }^{26}$ Any mix of state, city, private, and NGO ownership

${ }^{27}$ Includes both fully and partially foreign ownership
} 
The share of the foreign owned firms in the region is defined as

foreign_share $_{j}=\frac{\text { foreign }_{j}}{\text { total }_{j}}$

where $\mathrm{j}$ is a region as defined in the Table 2

foreign $n_{j}$ is a number of workers in foreign owned companies in the region $\mathrm{j}$

total $_{\mathrm{j}}$ is a total number of workers in the region $\mathrm{j}$

Results are presented in the Table A4:

Table A4 Distribution of labor force by type of ownership

\begin{tabular}{|c|c|c|c|c|c|c|c|}
\hline \multirow[b]{2}{*}{ Code } & \multirow[b]{2}{*}{ Region } & \multicolumn{6}{|c|}{ Share of workers by type of ownership } \\
\hline & & State & City & Private & NGO & $\begin{array}{c}\text { Mixed } \\
\text { Russian }\end{array}$ & Foreign \\
\hline rus & Russian Federation & 0.21 & 0.16 & 0.50 & 0.01 & 0.09 & 0.03 \\
\hline cen & Central Federal Okrug & 0.20 & 0.15 & 0.51 & 0.01 & 0.09 & 0.04 \\
\hline bel & Belgorodskaya & 0.13 & 0.19 & 0.61 & 0.01 & 0.06 & 0.01 \\
\hline bry & Bryanskaya & 0.19 & 0.17 & 0.56 & 0.01 & 0.07 & 0.01 \\
\hline vla & Vladimirskaya & 0.17 & 0.17 & 0.53 & 0.01 & 0.09 & 0.03 \\
\hline vor & Voronezhskaya & 0.20 & 0.15 & 0.58 & 0.01 & 0.06 & 0.01 \\
\hline iva & Ivanovskaya & 0.22 & 0.15 & 0.52 & 0.02 & 0.08 & 0.02 \\
\hline kal & Kaluzhskaya & 0.22 & 0.15 & 0.51 & 0.01 & 0.07 & 0.03 \\
\hline kos & Kostromskaya & 0.21 & 0.21 & 0.49 & 0.01 & 0.07 & 0.01 \\
\hline krs & Kurskaya & 0.22 & 0.11 & 0.58 & 0.01 & 0.07 & 0.02 \\
\hline lip & Lipetskaya & 0.15 & 0.18 & 0.47 & 0.01 & 0.07 & 0.12 \\
\hline mos & Moskovskaya & 0.22 & 0.18 & 0.47 & 0.01 & 0.09 & 0.03 \\
\hline orl & Orlovskaya & 0.21 & 0.13 & 0.48 & 0.01 & 0.14 & 0.02 \\
\hline rya & Ryazanskaya & 0.17 & 0.17 & 0.56 & 0.01 & 0.07 & 0.02 \\
\hline smo & Smolenskaya & 0.22 & 0.18 & 0.51 & 0.01 & 0.07 & 0.01 \\
\hline tam & Tambovskaya & 0.20 & 0.18 & 0.55 & 0.01 & 0.04 & 0.02 \\
\hline tve & Tverskaya & 0.20 & 0.17 & 0.51 & 0.01 & 0.09 & 0.01 \\
\hline tul & Tulskaya & 0.16 & 0.16 & 0.45 & 0.01 & 0.16 & 0.06 \\
\hline yar & Yaroslavskaya & 0.16 & 0.18 & 0.48 & 0.01 & 0.15 & 0.03 \\
\hline msk & Moscow city & 0.22 & 0.11 & 0.51 & 0.01 & 0.11 & 0.06 \\
\hline nor & North West Federal Okrug & 0.26 & 0.13 & 0.49 & 0.01 & 0.07 & 0.05 \\
\hline krl & The Republic of Karelia & 0.24 & 0.21 & 0.39 & 0.01 & 0.10 & 0.05 \\
\hline kom & The Republic of Komi & 0.21 & 0.22 & 0.39 & 0.00 & 0.13 & 0.05 \\
\hline arh & Arkhangelskaya & 0.29 & 0.21 & 0.38 & 0.00 & 0.06 & 0.06 \\
\hline nao & Nenetskiy AO & 0.27 & 0.19 & 0.45 & 0.00 & 0.03 & 0.06 \\
\hline vol & Vologodskaya & 0.15 & 0.19 & 0.49 & 0.00 & 0.14 & 0.03 \\
\hline$k l g$ & Kaliningradskaya & 0.24 & 0.16 & 0.50 & 0.01 & 0.06 & 0.03 \\
\hline len & Leningradskaya & 0.17 & 0.18 & 0.54 & 0.00 & 0.05 & 0.06 \\
\hline mur & Murmanskaya & 0.30 & 0.20 & 0.38 & 0.00 & 0.10 & 0.02 \\
\hline nov & Novgorodskaya & 0.19 & 0.21 & 0.45 & 0.01 & 0.09 & 0.06 \\
\hline psk & Pskovskaya & 0.22 & 0.18 & 0.54 & 0.01 & 0.03 & 0.02 \\
\hline$s p b$ & Saint Petersburg city & 0.34 & 0.00 & 0.55 & 0.01 & 0.05 & 0.05 \\
\hline sou & South Federal Okrug & 0.18 & 0.15 & 0.57 & 0.01 & 0.07 & 0.01 \\
\hline ady & The Republic of Adygeya & 0.21 & 0.18 & 0.53 & 0.01 & 0.06 & 0.00 \\
\hline
\end{tabular}




\begin{tabular}{|c|c|c|c|c|c|c|c|}
\hline \multirow[b]{2}{*}{ Code } & \multirow[b]{2}{*}{ Region } & \multicolumn{6}{|c|}{ Share of workers by type of ownership } \\
\hline & & State & City & Private & NGO & $\begin{array}{c}\text { Mixed } \\
\text { Russian }\end{array}$ & Foreign \\
\hline dag & The Republic of Dagestan & 0.25 & 0.15 & 0.55 & 0.01 & 0.04 & 0.01 \\
\hline ing & The Republic of Ingushetia & 0.34 & 0.15 & 0.49 & 0.01 & 0.02 & 0.01 \\
\hline kab & Kabardino Balkaria & 0.19 & 0.19 & 0.49 & 0.01 & 0.11 & 0.00 \\
\hline klr & The Republic of Kalmykia & 0.28 & 0.22 & 0.43 & 0.01 & 0.07 & 0.00 \\
\hline kar & Karachaevo Cherkessia & 0.30 & 0.09 & 0.57 & 0.01 & 0.04 & 0.00 \\
\hline sev & North Osetia & 0.30 & 0.18 & 0.45 & 0.01 & 0.06 & 0.01 \\
\hline $\begin{array}{l}\text { cher } \\
\text { kdk }\end{array}$ & $\begin{array}{l}\text { The Chechen Republic } \\
\text { Krasnodarsky krai }\end{array}$ & 0.15 & 0.17 & 0.58 & 0.01 & 0.08 & $\ldots$ \\
\hline sta & Stavropolsky krai & 0.22 & 0.09 & 0.59 & 0.01 & 0.05 & 0.04 \\
\hline ast & Astrakhanskaya & 0.23 & 0.19 & 0.46 & 0.01 & 0.06 & 0.05 \\
\hline vlg & Volgogradskaya & 0.15 & 0.18 & 0.59 & 0.01 & 0.07 & 0.01 \\
\hline ros & Rostovskaya & 0.15 & 0.15 & 0.59 & 0.01 & 0.09 & 0.01 \\
\hline pvl & Provlzhsky Federal Okrug & 0.21 & 0.16 & 0.48 & 0.01 & 0.13 & 0.02 \\
\hline bas & Bashkortostan & 0.19 & 0.22 & 0.37 & 0.01 & 0.22 & 0.00 \\
\hline mar & The Republic of Mari El & 0.23 & 0.19 & 0.44 & 0.01 & 0.12 & 0.01 \\
\hline mor & The Republic of Mordovia & 0.25 & 0.16 & 0.40 & 0.01 & 0.17 & 0.00 \\
\hline tat & The Republic of Tatarstan & 0.35 & 0.05 & 0.38 & 0.01 & 0.16 & 0.05 \\
\hline$u d m$ & The Republic of Udmurtia & 0.21 & 0.18 & 0.45 & 0.01 & 0.14 & 0.01 \\
\hline $\operatorname{chv}$ & The Republic of Chuvashia & 0.16 & 0.17 & 0.49 & 0.02 & 0.14 & 0.02 \\
\hline kir & Kirovskaya & 0.22 & 0.16 & 0.48 & 0.01 & 0.10 & 0.03 \\
\hline niz & Nizhegorodskaya & 0.17 & 0.17 & 0.55 & 0.01 & 0.08 & 0.02 \\
\hline ore & Orenburgskaya & 0.16 & 0.19 & 0.54 & 0.00 & 0.11 & 0.01 \\
\hline pen & Penzenskaya & 0.26 & 0.11 & 0.55 & 0.01 & 0.06 & 0.00 \\
\hline per & Permskaya & 0.17 & 0.18 & 0.51 & 0.01 & 0.09 & 0.03 \\
\hline kpao & Komi-Perm AO & 0.28 & 0.15 & 0.49 & 0.00 & 0.07 & 0.01 \\
\hline sam & Samarskaya & 0.14 & 0.16 & 0.51 & 0.01 & 0.15 & 0.03 \\
\hline sar & Saratovskaya & 0.21 & 0.16 & 0.55 & 0.01 & 0.04 & 0.02 \\
\hline ulo & Ulyanovskaya & 0.21 & 0.17 & 0.41 & 0.01 & 0.19 & 0.01 \\
\hline ura & Urals Federal Okrug & 0.18 & 0.19 & 0.49 & 0.01 & 0.08 & 0.06 \\
\hline krg & Kurganskaya & 0.19 & 0.18 & 0.56 & 0.01 & 0.05 & 0.01 \\
\hline sve & Sverdlovskaya & 0.21 & 0.18 & 0.40 & 0.01 & 0.07 & 0.12 \\
\hline tum & Tumenskaya & 0.12 & 0.20 & 0.58 & 0.00 & 0.09 & 0.01 \\
\hline hmao & Hanty-Mansi AO & 0.08 & 0.21 & 0.60 & 0.00 & 0.09 & 0.01 \\
\hline ynao & Yamal-Nenets AO & 0.09 & 0.22 & 0.55 & 0.00 & 0.12 & 0.01 \\
\hline chl & Chelyabinskaya & 0.19 & 0.19 & 0.46 & 0.01 & 0.09 & 0.07 \\
\hline sib & Siberia Federal Okrug & 0.22 & 0.19 & 0.48 & 0.01 & 0.08 & 0.02 \\
\hline alr & Altay republic & 0.28 & 0.23 & 0.45 & 0.01 & 0.03 & 0.00 \\
\hline bur & The Republic of Buryatia & 0.25 & 0.22 & 0.41 & 0.02 & 0.06 & 0.04 \\
\hline tyv & The Republic of Tyva & 0.34 & 0.32 & 0.30 & 0.00 & 0.04 & 0.00 \\
\hline hak & The Republic of Khakasia & 0.23 & 0.16 & 0.51 & 0.01 & 0.07 & 0.04 \\
\hline alt & Altaisky krai & 0.18 & 0.20 & 0.54 & 0.01 & 0.05 & 0.02 \\
\hline kra & Krasnoyarsky krai & 0.21 & 0.20 & 0.42 & 0.00 & 0.11 & 0.06 \\
\hline tao & Tajmyr AO & 0.36 & 0.17 & 0.43 & 0.00 & 0.03 & 0.00 \\
\hline evao & Evenkskiy AO & 0.49 & 0.21 & 0.20 & 0.00 & 0.11 & $\ldots$ \\
\hline irk & Irkutskaya & 0.21 & 0.20 & 0.46 & 0.00 & 0.10 & 0.02 \\
\hline uoao & Ust-Ordyn Buryat AO & 0.15 & 0.25 & 0.52 & 0.00 & 0.07 & 0.00 \\
\hline kem & Kemerovskaya & 0.16 & 0.22 & 0.50 & 0.00 & 0.11 & 0.00 \\
\hline nvs & Novosibirskaya & 0.28 & 0.15 & 0.48 & 0.01 & 0.07 & 0.01 \\
\hline oms & Omskaya & 0.19 & 0.17 & 0.56 & 0.01 & 0.07 & 0.01 \\
\hline tom & Tomskaya & 0.23 & 0.18 & 0.49 & 0.00 & 0.08 & 0.01 \\
\hline chi & Chitinskaya & 0.33 & 0.19 & 0.38 & 0.01 & 0.07 & 0.02 \\
\hline abao & Aginsk Buryat AO & 0.35 & 0.07 & 0.54 & 0.01 & 0.02 & 0.01 \\
\hline far & Far East Federal Okrug & 0.29 & 0.15 & 0.42 & 0.00 & 0.11 & 0.02 \\
\hline sah & The Republic of Sakha & 0.52 & 0.01 & 0.28 & 0.00 & 0.18 & 0.00 \\
\hline pri & Primorsky krai & 0.23 & 0.16 & 0.47 & 0.01 & 0.11 & 0.03 \\
\hline hab & Khabarovsky krai & 0.29 & 0.18 & 0.38 & 0.00 & 0.11 & 0.03 \\
\hline
\end{tabular}




\begin{tabular}{llcccccc}
\hline \multirow{2}{*}{ Code } & \multicolumn{2}{c}{ Region } & \multicolumn{6}{c}{ Share of workers by type of ownership } \\
\cline { 3 - 7 } & & State & City & Private & NGO & $\begin{array}{c}\text { Mixed } \\
\text { Russian }\end{array}$ & Foreign \\
\hline $\mathbf{a m u}$ & Amurskaya & 0.26 & 0.17 & 0.47 & 0.00 & 0.08 & $\mathbf{0 . 0 1}$ \\
kam & Kamchatskaya & 0.28 & 0.18 & 0.46 & 0.00 & 0.07 & $\mathbf{0 . 0 0}$ \\
$\mathbf{k o a o}$ & Koryak AO & 0.29 & 0.27 & 0.38 & 0.00 & 0.06 & $\mathbf{0 . 0 0}$ \\
$\mathbf{m a g}$ & Magadanskaya & 0.23 & 0.21 & 0.46 & 0.00 & 0.08 & $\mathbf{0 . 0 2}$ \\
sao & Sakhalinskaya & 0.19 & 0.19 & 0.52 & 0.01 & 0.07 & $\mathbf{0 . 0 2}$ \\
eao & Jewish AO & 0.31 & 0.21 & 0.40 & 0.00 & 0.07 & $\mathbf{0 . 0 1}$ \\
chu & Chukotsky AO & 0.47 & 0.23 & 0.18 & 0.00 & 0.11 & $\mathbf{0 . 0 2}$ \\
\hline
\end{tabular}

Source: Regions of Russia 2003

\section{Distribution of labor force by type of ownership for 10 bigger regions}

Table A5 presents shares of total regional labor force employed by state, city, local private company, non-government, mixed Russian, and foreign organizations for 10 bigger regions:

Moscow, Saint Petersburg, Tumen, Northwest, North, Center, South, Ural, Siberia, and Far East regions. Aggregation from the regional level to the 10 big regions is conducted according to the following formula:

$$
\text { share }_{k j}=\frac{\sum_{i \in k} \text { Labor_by_ownership }_{i j}}{\sum_{i \in k} \text { Total_labor }_{i}}
$$

where $i$ is on of the 89 regions of Russia that belongs to a bigger regional markets $k$, and $j$ is a type of ownership.

Table A5 Distribution of labor force by type of ownership. Ten bigger regions

\begin{tabular}{llcccccc}
\hline \multirow{2}{*}{ Code } & \multicolumn{6}{c}{ Market } & \multicolumn{5}{c}{ Share of workers by type of ownership } \\
& & State & City & Private & NGO & Mixed Russian & Foreign \\
\hline Msc & Moscow & 0.22 & 0.13 & 0.49 & 0.01 & 0.10 & 0.05 \\
Stp & Saint Petersburgh & 0.30 & 0.04 & 0.54 & 0.01 & 0.05 & 0.05 \\
Tmn & Tumen Region & 0.12 & 0.20 & 0.58 & 0.00 & 0.09 & 0.01 \\
Vgd & Northwest & 0.19 & 0.19 & 0.50 & 0.01 & 0.09 & 0.03 \\
Nor & North & 0.26 & 0.21 & 0.38 & 0.00 & 0.09 & 0.05 \\
Cen & Center & 0.19 & 0.16 & 0.53 & 0.01 & 0.09 & 0.03 \\
Sou & South & 0.19 & 0.16 & 0.56 & 0.01 & 0.07 & 0.02 \\
Url & Ural & 0.21 & 0.16 & 0.46 & 0.01 & 0.12 & 0.04 \\
Sib & Siberia & 0.23 & 0.18 & 0.47 & 0.01 & 0.09 & 0.02 \\
Far & Far East & 0.26 & 0.18 & 0.44 & 0.01 & 0.10 & 0.02 \\
\hline
\end{tabular}

Source: Regions of Russia 2003 


\subsection{BEEPS}

\subsubsection{Variables}

We define a variable workers $\mathrm{ijk}_{\mathrm{ijk}}$ as a number of permanent, full time employees that a firm $\mathrm{k}$ in industry i from country j had in 2002 (Question 91a1 of the survey).

We define an industry i according to the firm's main area of activity in terms of sales (Question S.3)

Finally, we define a variable ownership that takes two values: foreign and local. A company k is the foreign owned company if at least $10 \%$ of the company is owned by a private foreign company or organization (Question S.4c).

\subsubsection{Country Aggregation}

We aggregate the variable workers $_{\mathrm{ijk}}$ in two categories:

$$
\begin{aligned}
& \text { foreign }_{i j}=\sum_{k \in \text { foreign }} \text { wor ker } s_{i j k} \\
& \text { local }_{i j}=\sum_{k \in l o c a l} \text { wor ker } s_{i j k}
\end{aligned}
$$

Then, the share of the foreign owned firms in an industry $\mathrm{i}$ in a country $\mathrm{j}$ is defined as

$$
\text { foreign_share }_{i j}=\frac{\text { foreign }_{i j}}{\text { foreign }_{i j}+\text { local }_{i j}}
$$

The results are presented in the Table A6. 
Sector

Transport

communication and

Mining Construction Manufacturing

\section{Country}

\begin{tabular}{|c|c|c|c|c|c|}
\hline \multirow[t]{3}{*}{ Albania } & $1.00 \mathrm{a}$ & 0.11 & 0.18 & 0.36 & 0.10 \\
\hline & $0.00 b$ & 0.32 & 0.39 & 0.50 & 0.30 \\
\hline & $2 c$ & 19 & 62 & 14 & 42 \\
\hline \multirow[t]{3}{*}{ Armenia } & 0.33 & 0.00 & 0.19 & 0.10 & 0.17 \\
\hline & 0.58 & 0.00 & 0.39 & 0.32 & 0.38 \\
\hline & 3 & 11 & 64 & 10 & 47 \\
\hline \multirow[t]{3}{*}{ Azerbaijan } & 0.00 & 0.11 & 0.24 & 0.40 & 0.09 \\
\hline & 0.00 & 0.32 & 0.43 & 0.52 & 0.29 \\
\hline & 3 & 27 & 49 & 10 & 57 \\
\hline \multirow[t]{3}{*}{ Belarus } & . & 0.07 & 0.38 & 0.40 & 0.18 \\
\hline & . & 0.26 & 0.49 & 0.50 & 0.38 \\
\hline & 0 & 68 & 42 & 25 & 80 \\
\hline \multirow[t]{3}{*}{$\mathrm{BiH}$} & 0.00 & 0.00 & 0.10 & 0.17 & 0.18 \\
\hline & 0.00 & 0.00 & 0.31 & 0.39 & 0.39 \\
\hline & 3 & 12 & 67 & 12 & 56 \\
\hline \multirow[t]{3}{*}{ Bulgaria } & 0.33 & 0.00 & 0.24 & 0.16 & 0.17 \\
\hline & 0.58 & 0.00 & 0.43 & 0.37 & 0.38 \\
\hline & 3 & 19 & 49 & 25 & 93 \\
\hline \multirow[t]{3}{*}{ Croatia } & 0.33 & 0.09 & 0.14 & 0.07 & 0.31 \\
\hline & 0.58 & 0.29 & 0.35 & 0.26 & 0.47 \\
\hline & 3 & 23 & 37 & 15 & 58 \\
\hline
\end{tabular}




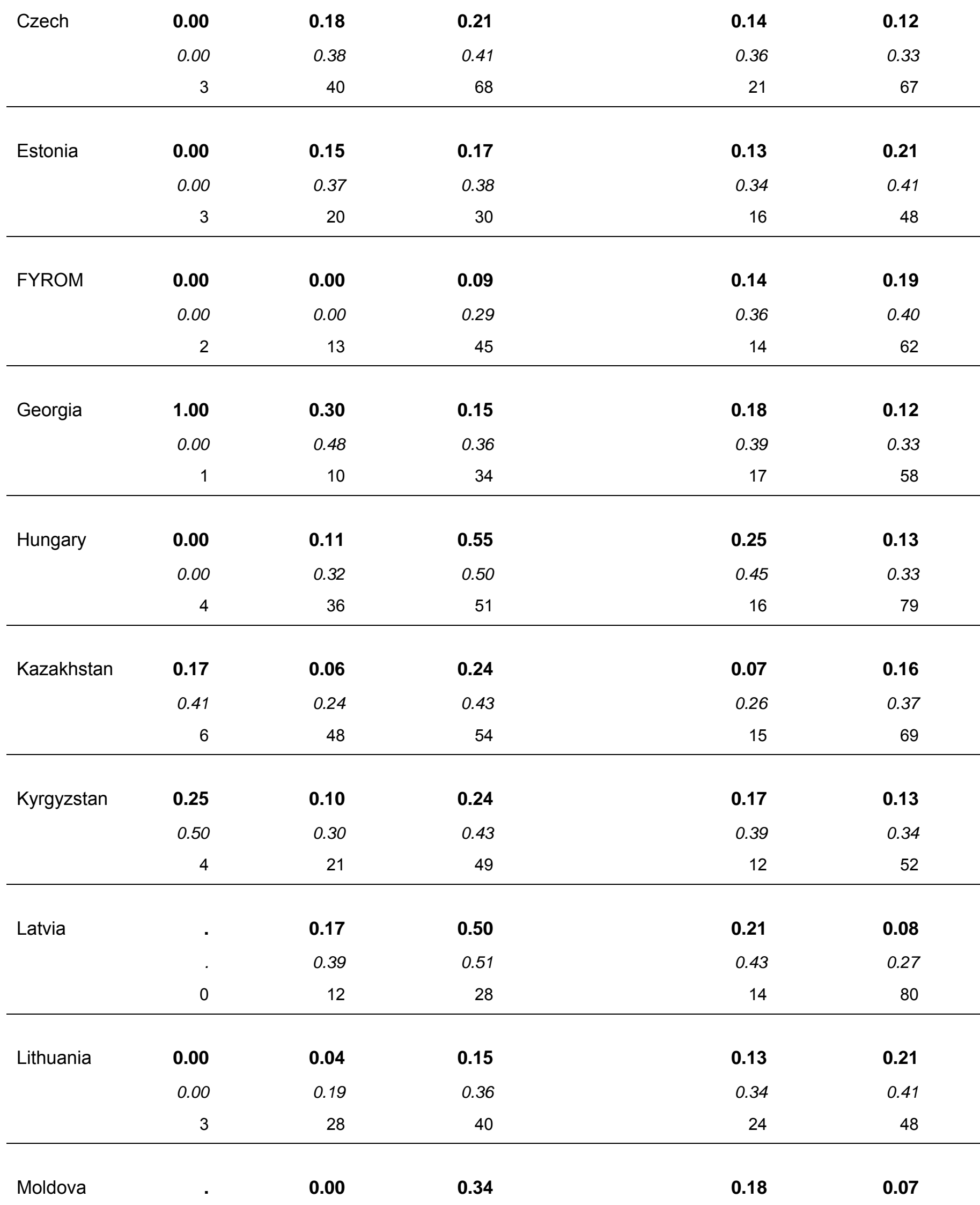




\begin{tabular}{|c|c|c|c|c|c|}
\hline & . & 0.00 & 0.48 & 0.40 & 0.25 \\
\hline & 0 & 5 & 50 & 11 & 74 \\
\hline \multirow[t]{3}{*}{ Poland } & . & 0.11 & 0.15 & 0.17 & 0.20 \\
\hline & . & 0.31 & 0.36 & 0.38 & 0.40 \\
\hline & 0 & 76 & 114 & 54 & 168 \\
\hline \multirow[t]{3}{*}{ Romania } & . & 0.17 & 0.21 & 0.25 & 0.12 \\
\hline & . & 0.38 & 0.41 & 0.44 & 0.32 \\
\hline & 0 & 24 & 82 & 20 & 68 \\
\hline \multirow[t]{3}{*}{ Russia } & 0.29 & 0.08 & 0.17 & 0.24 & 0.16 \\
\hline & 0.49 & 0.27 & 0.38 & 0.43 & 0.36 \\
\hline & 7 & 80 & 128 & 37 & 135 \\
\hline \multirow[t]{3}{*}{ Slovakia } & - & 0.18 & 0.17 & 0.40 & 0.22 \\
\hline & . & 0.39 & 0.38 & 0.51 & 0.42 \\
\hline & 0 & 17 & 29 & 15 & 46 \\
\hline \multirow[t]{3}{*}{ Slovenia } & 0.00 & 0.00 & 0.36 & 0.00 & 0.15 \\
\hline & 0.00 & 0.00 & 0.49 & 0.00 & 0.36 \\
\hline & 3 & 28 & 47 & 16 & 40 \\
\hline \multirow[t]{3}{*}{ Tajikistan } & 0.20 & 0.00 & 0.10 & 0.17 & 0.00 \\
\hline & 0.45 & 0.00 & 0.31 & 0.39 & 0.00 \\
\hline & 5 & 20 & 48 & 12 & 47 \\
\hline \multirow[t]{3}{*}{ Turkey } & 0.00 & 0.03 & 0.17 & 0.21 & 0.10 \\
\hline & 0.00 & 0.17 & 0.37 & 0.42 & 0.30 \\
\hline & 8 & 33 & 151 & 28 & 165 \\
\hline \multirow[t]{3}{*}{ Ukraine } & 0.00 & 0.04 & 0.15 & 0.14 & 0.27 \\
\hline & 0.00 & 0.19 & 0.36 & 0.35 & 0.45 \\
\hline & 2 & 57 & 139 & 29 & 114 \\
\hline \multirow[t]{2}{*}{ Uzbekistan } & 0.00 & 0.02 & 0.39 & 0.16 & 0.18 \\
\hline & 0.00 & 0.16 & 0.49 & 0.37 & 0.39 \\
\hline
\end{tabular}


Yugoslavia

$\begin{array}{rr}0.00 & 0.06 \\ 0.00 & 0.24 \\ 4 & 18\end{array}$

.06

0.12

0.23

0.27

18

0.32

0.43

0.45

68

22

73

Total by

sector

0.14

0.08

0.21

0.19

0.16

0.35

0.27

0.41

0.40

0.37

77

806

1676

523

2018

Notes:

a Share of employed by a company with at least $10 \%$ of foreign ownership

\begin{tabular}{|c|c|c|c|c|c|c|c|c|c|}
\hline Country & 옳 & 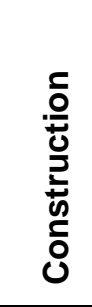 & 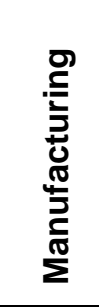 & 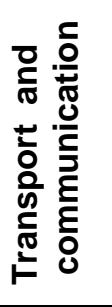 & 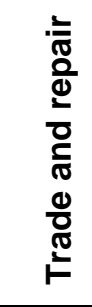 & 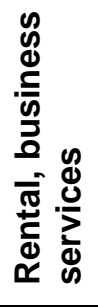 & 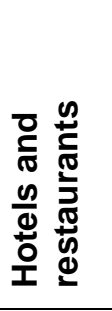 & 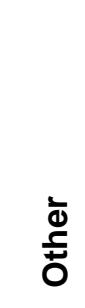 & 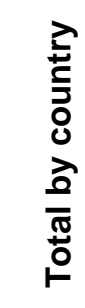 \\
\hline \multirow[t]{3}{*}{ Albania } & $1.00^{a}$ & 0.11 & 0.18 & 0.36 & 0.10 & 0.11 & 0.08 & 0.00 & 0.15 \\
\hline & $0.00^{b}$ & 0.32 & 0.39 & 0.50 & 0.30 & 0.33 & 0.28 & 0.00 & 0.36 \\
\hline & $2^{\mathrm{c}}$ & 19 & 62 & 14 & 42 & 9 & 13 & 9 & 170 \\
\hline \multirow[t]{3}{*}{ Armenia } & 0.33 & 0.00 & 0.19 & 0.10 & 0.17 & 0.10 & 0.25 & 0.00 & 0.16 \\
\hline & 0.58 & 0.00 & 0.39 & 0.32 & 0.38 & 0.32 & 0.45 & 0.00 & 0.37 \\
\hline & 3 & 11 & 64 & 10 & 47 & 10 & 16 & 10 & 171 \\
\hline \multirow[t]{3}{*}{ Azerbaijan } & 0.00 & 0.11 & 0.24 & 0.40 & 0.09 & 0.13 & 0.22 & 0.00 & 0.16 \\
\hline & 0.00 & 0.32 & 0.43 & 0.52 & 0.29 & 0.35 & 0.44 & 0.00 & 0.37 \\
\hline & 3 & 27 & 49 & 10 & 57 & 8 & 9 & 6 & 169 \\
\hline \multirow[t]{3}{*}{ Belarus } & . & 0.07 & 0.38 & 0.40 & 0.18 & 0.13 & 0.20 & 0.07 & 0.20 \\
\hline & . & 0.26 & 0.49 & 0.50 & 0.38 & 0.35 & 0.45 & 0.26 & 0.40 \\
\hline & 0 & 68 & 42 & 25 & 80 & 15 & 5 & 15 & 250 \\
\hline \multirow[t]{3}{*}{$\mathrm{BiH}$} & 0.00 & 0.00 & 0.10 & 0.17 & 0.18 & 0.29 & 0.07 & 0.13 & 0.13 \\
\hline & 0.00 & 0.00 & 0.31 & 0.39 & 0.39 & 0.49 & 0.26 & 0.35 & 0.33 \\
\hline & 3 & 12 & 67 & 12 & 56 & 7 & 15 & 8 & 180 \\
\hline \multirow[t]{3}{*}{ Bulgaria } & 0.33 & 0.00 & 0.24 & 0.16 & 0.17 & 0.18 & 0.10 & 0.06 & 0.16 \\
\hline & 0.58 & 0.00 & 0.43 & 0.37 & 0.38 & 0.39 & 0.30 & 0.24 & 0.37 \\
\hline & 3 & 19 & 49 & 25 & 93 & 22 & 21 & 17 & 249 \\
\hline \multirow[t]{3}{*}{ Croatia } & 0.33 & 0.09 & 0.14 & 0.07 & 0.31 & 0.18 & 0.10 & 0.00 & 0.18 \\
\hline & 0.58 & 0.29 & 0.35 & 0.26 & 0.47 & 0.39 & 0.32 & 0.00 & 0.38 \\
\hline & 3 & 23 & 37 & 15 & 58 & 28 & 10 & 10 & 184 \\
\hline \multirow[t]{3}{*}{ Czech } & 0.00 & 0.18 & 0.21 & 0.14 & 0.12 & 0.16 & 0.13 & 0.17 & 0.16 \\
\hline & 0.00 & 0.38 & 0.41 & 0.36 & 0.33 & 0.37 & 0.34 & 0.39 & 0.37 \\
\hline & 3 & 40 & 68 & 21 & 67 & 32 & 23 & 12 & 266 \\
\hline \multirow[t]{2}{*}{ Estonia } & 0.00 & 0.15 & 0.17 & 0.13 & 0.21 & 0.25 & 0.07 & 0.22 & 0.18 \\
\hline & 0.00 & 0.37 & 0.38 & 0.34 & 0.41 & 0.44 & 0.26 & 0.44 & 0.38 \\
\hline
\end{tabular}




\begin{tabular}{|c|c|c|c|c|c|c|c|c|c|}
\hline Country & & 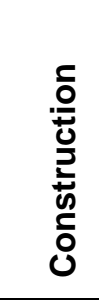 & 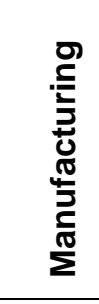 & 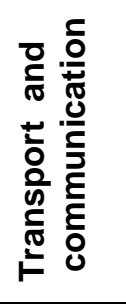 & 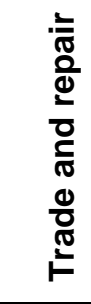 & 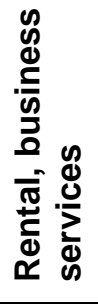 & 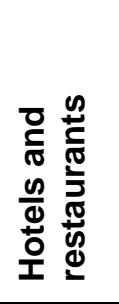 & $\begin{array}{l}\text { む } \\
\text { ঠे }\end{array}$ & 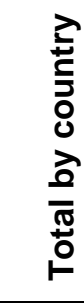 \\
\hline & 3 & 20 & 30 & 16 & 48 & 28 & 15 & 9 & 169 \\
\hline \multirow[t]{3}{*}{ FYROM } & 0.00 & 0.00 & 0.09 & 0.14 & 0.19 & 0.09 & 0.14 & 0.17 & 0.13 \\
\hline & 0.00 & 0.00 & 0.29 & 0.36 & 0.40 & 0.30 & 0.36 & 0.41 & 0.34 \\
\hline & 2 & 13 & 45 & 14 & 62 & 11 & 14 & 6 & 167 \\
\hline \multirow[t]{3}{*}{ Georgia } & 1.00 & 0.30 & 0.15 & 0.18 & 0.12 & 0.16 & 0.17 & 0.09 & 0.15 \\
\hline & 0.00 & 0.48 & 0.36 & 0.39 & 0.33 & 0.37 & 0.39 & 0.29 & 0.36 \\
\hline & 1 & 10 & 34 & 17 & 58 & 19 & 12 & 23 & 174 \\
\hline \multirow[t]{3}{*}{ Hungary } & 0.00 & 0.11 & 0.55 & 0.25 & 0.13 & 0.27 & 0.20 & 0.06 & 0.23 \\
\hline & 0.00 & 0.32 & 0.50 & 0.45 & 0.33 & 0.45 & 0.41 & 0.24 & 0.42 \\
\hline & 4 & 36 & 51 & 16 & 79 & 30 & 15 & 17 & 248 \\
\hline \multirow[t]{3}{*}{ Kazakhstan } & 0.17 & 0.06 & 0.24 & 0.07 & 0.16 & 0.14 & 0.18 & 0.10 & 0.15 \\
\hline & 0.41 & 0.24 & 0.43 & 0.26 & 0.37 & 0.35 & 0.40 & 0.32 & 0.36 \\
\hline & 6 & 48 & 54 & 15 & 69 & 37 & 11 & 10 & 250 \\
\hline \multirow[t]{3}{*}{ Kyrgyzstan } & 0.25 & 0.10 & 0.24 & 0.17 & 0.13 & 0.00 & 0.50 & 0.09 & 0.17 \\
\hline & 0.50 & 0.30 & 0.43 & 0.39 & 0.34 & 0.00 & 0.53 & 0.30 & 0.38 \\
\hline & 4 & 21 & 49 & 12 & 52 & 14 & 8 & 11 & 171 \\
\hline \multirow[t]{3}{*}{ Latvia } & . & 0.17 & 0.50 & 0.21 & 0.08 & 0.12 & 0.00 & 0.00 & 0.16 \\
\hline & . & 0.39 & 0.51 & 0.43 & 0.27 & 0.33 & 0.00 & 0.00 & 0.37 \\
\hline & 0 & 12 & 28 & 14 & 80 & 25 & 9 & 7 & 175 \\
\hline \multirow[t]{3}{*}{ Lithuania } & 0.00 & 0.04 & 0.15 & 0.13 & 0.21 & 0.09 & 0.27 & 0.33 & 0.16 \\
\hline & 0.00 & 0.19 & 0.36 & 0.34 & 0.41 & 0.29 & 0.45 & 0.52 & 0.36 \\
\hline & 3 & 28 & 40 & 24 & 48 & 23 & 26 & 6 & 198 \\
\hline \multirow[t]{3}{*}{ Moldova } & . & 0.00 & 0.34 & 0.18 & 0.07 & 0.67 & 0.00 & 0.14 & 0.17 \\
\hline & . & 0.00 & 0.48 & 0.40 & 0.25 & 0.58 & 0.00 & 0.35 & 0.37 \\
\hline & 0 & 5 & 50 & 11 & 74 & 3 & 9 & 22 & 174 \\
\hline \multirow[t]{3}{*}{ Poland } & . & 0.11 & 0.15 & 0.17 & 0.20 & 0.13 & 0.21 & 0.04 & 0.15 \\
\hline & . & 0.31 & 0.36 & 0.38 & 0.40 & 0.34 & 0.43 & 0.20 & 0.36 \\
\hline & 0 & 76 & 114 & 54 & 168 & 47 & 14 & 25 & 498 \\
\hline \multirow[t]{3}{*}{ Romania } & . & 0.17 & 0.21 & 0.25 & 0.12 & 0.27 & 0.12 & 0.11 & 0.18 \\
\hline & . & 0.38 & 0.41 & 0.44 & 0.32 & 0.45 & 0.33 & 0.32 & 0.38 \\
\hline & 0 & 24 & 82 & 20 & 68 & 26 & 17 & 18 & 255 \\
\hline \multirow[t]{3}{*}{ Russia } & 0.29 & 0.08 & 0.17 & 0.24 & 0.16 & 0.23 & 0.21 & 0.12 & 0.16 \\
\hline & 0.49 & 0.27 & 0.38 & 0.43 & 0.36 & 0.42 & 0.42 & 0.33 & 0.37 \\
\hline & 7 & 80 & 128 & 37 & 135 & 40 & 19 & 58 & 504 \\
\hline \multirow[t]{3}{*}{ Slovakia } & . & 0.18 & 0.17 & 0.40 & 0.22 & 0.11 & 0.00 & 0.17 & 0.18 \\
\hline & . & 0.39 & 0.38 & 0.51 & 0.42 & 0.31 & 0.00 & 0.39 & 0.38 \\
\hline & 0 & 17 & 29 & 15 & 46 & 38 & 12 & 12 & 169 \\
\hline \multirow[t]{3}{*}{ Slovenia } & 0.00 & 0.00 & 0.36 & 0.00 & 0.15 & 0.12 & 0.07 & 0.00 & 0.15 \\
\hline & 0.00 & 0.00 & 0.49 & 0.00 & 0.36 & 0.33 & 0.26 & 0.00 & 0.36 \\
\hline & 3 & 28 & 47 & 16 & 40 & 33 & 15 & 6 & 188 \\
\hline \multirow[t]{2}{*}{ Tajikistan } & 0.20 & 0.00 & 0.10 & 0.17 & 0.00 & 0.00 & 0.00 & 0.00 & 0.05 \\
\hline & 0.45 & 0.00 & 0.31 & 0.39 & 0.00 & 0.00 & 0.00 & 0.00 & 0.21 \\
\hline
\end{tabular}




\begin{tabular}{|c|c|c|c|c|c|c|c|c|c|}
\hline Country & $\frac{\stackrel{D}{E}}{\stackrel{S}{\Sigma}}$ & 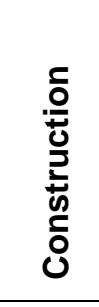 & 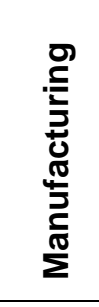 & 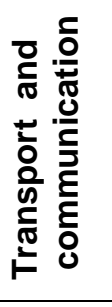 & 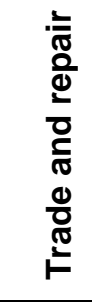 & 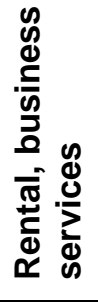 & 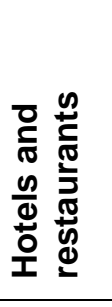 & $\frac{\grave{\Phi}}{\stackrel{ \pm}{0}}$ & 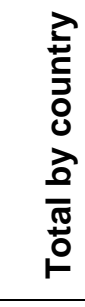 \\
\hline & 5 & 20 & 48 & 12 & 47 & 18 & 10 & 14 & 174 \\
\hline \multirow[t]{3}{*}{ Turkey } & 0.00 & 0.03 & 0.17 & 0.21 & 0.10 & 0.26 & 0.07 & 0.05 & 0.12 \\
\hline & 0.00 & 0.17 & 0.37 & 0.42 & 0.30 & 0.45 & 0.25 & 0.21 & 0.33 \\
\hline & 8 & 33 & 151 & 28 & 165 & 34 & 73 & 22 & 514 \\
\hline \multirow[t]{3}{*}{ Ukraine } & 0.00 & 0.04 & 0.15 & 0.14 & 0.27 & 0.22 & 0.21 & 0.03 & 0.17 \\
\hline & 0.00 & 0.19 & 0.36 & 0.35 & 0.45 & 0.41 & 0.42 & 0.19 & 0.38 \\
\hline & 2 & 57 & 139 & 29 & 114 & 65 & 28 & 29 & 463 \\
\hline \multirow[t]{3}{*}{ Uzbekistan } & 0.00 & 0.02 & 0.39 & 0.16 & 0.18 & 0.04 & 0.12 & 0.10 & 0.17 \\
\hline & 0.00 & 0.16 & 0.49 & 0.37 & 0.39 & 0.20 & 0.33 & 0.32 & 0.38 \\
\hline & 5 & 41 & 51 & 19 & 92 & 25 & 17 & 10 & 260 \\
\hline \multirow[t]{3}{*}{ Yugoslavia } & 0.00 & 0.06 & 0.12 & 0.23 & 0.27 & 0.15 & 0.17 & 0.06 & 0.17 \\
\hline & 0.00 & 0.24 & 0.32 & 0.43 & 0.45 & 0.37 & 0.38 & 0.24 & 0.38 \\
\hline & 4 & 18 & 68 & 22 & 73 & 26 & 18 & 17 & 246 \\
\hline \multirow[t]{3}{*}{$\begin{array}{l}\text { Total by } \\
\text { sector }\end{array}$} & 0.14 & 0.08 & 0.21 & 0.19 & 0.16 & 0.16 & 0.14 & 0.08 & 0.16 \\
\hline & 0.35 & 0.27 & 0.41 & 0.40 & 0.37 & 0.37 & 0.34 & 0.28 & 0.37 \\
\hline & 77 & 806 & 1676 & 523 & 2018 & 673 & 454 & 409 & 6636 \\
\hline
\end{tabular}

Notes: $\quad \begin{array}{ll}\text { a Share of employed by a company with at least } 10 \% \text { of foreign ownership } \\ \\ \text { b Standard deviation } \\ \text { c Number of observations }\end{array}$

Source: BEEPS 2002 


\section{Appendix B \\ Investment Ratings of the Regions of Russia}

To assess the investment climate and barriers to foreign direct investment, we use "The Rating of Investment Climate of Russia’s Regions in 2002-2003” published by Expert Rating Agency (Expert RA). Expert RA is a rating agency founded by Expert Magazine that has published its “Investment Rating of Russia’s Regions” every year since 1996. The evaluation of the investment climate is carried out for each of the 89 regions of Russia based on more than a hundred statistical indicators of regional development from various sources that include Rosstat, the Ministry of Finance, the Ministry of Economic Development, and The Central Bank.

The rating of investment climate is formed based on two primary measures: investment risk and investment potential of each region. The aggregate measure of investment risk is calculated based on the seven types of risks: legal, political, economic, financial, social, criminal, and ecological risks. The rating of a region by each type of risks is defined based on the index of risk calculated as the deviation from the all-Russia average level of risk that is set equal to 1 and aggregated to the overall index of risk An investment potential of a region is derived based on the eight regional indicators of economic potential in the following categories: labor, consumer demand, production, financial potential, institutional quality, innovations, infrastructure, and natural resources. The region's potential rating in each category is calculated according to the regional share in that category. The overall rating of investment potential is derived as a weighted average of investment potential in each category. For our sensitivity analysis, we chose the "investment potential rankings." 
Table 2 Investment Risk in 2003

\begin{tabular}{|c|c|c|c|c|c|c|c|c|c|}
\hline \multirow[b]{2}{*}{ Region } & \multirow{2}{*}{$\begin{array}{l}\text { Investment } \\
\text { risk rating } \\
\text { in } 2003\end{array}$} & \multirow{2}{*}{$\begin{array}{l}\text { Index of } \\
\text { investment } \\
\text { risk }\end{array}$} & \multicolumn{7}{|c|}{ Seven components of investment risk } \\
\hline & & & $\begin{array}{l}\text { Leg } \\
\text { al }\end{array}$ & $\begin{array}{l}\text { Polit } \\
\text { ical }\end{array}$ & $\begin{array}{l}\text { Econo } \\
\text { mic }\end{array}$ & $\begin{array}{l}\text { Fina } \\
\text { ncial }\end{array}$ & $\begin{array}{l}\text { Soc } \\
\text { ial }\end{array}$ & $\begin{array}{l}\text { Crimi } \\
\text { nal }\end{array}$ & $\begin{array}{l}\text { Ecolo } \\
\text { gical }\end{array}$ \\
\hline Novgorodskaya & 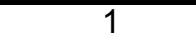 & 0.861 & 3 & 44 & 9 & 20 & 7 & 39 & 19 \\
\hline Yaroslavskaya & 2 & 0.871 & 1 & 74 & 48 & 22 & 2 & 45 & 50 \\
\hline Saint Petersburg city & 3 & 0.872 & 52 & 76 & 6 & 2 & 3 & 40 & 44 \\
\hline Belgorodskaya & 4 & 0.876 & 58 & 26 & 14 & 24 & 4 & 16 & 11 \\
\hline Orlovskaya & 5 & 0.885 & 24 & 6 & 15 & 23 & 8 & 33 & 74 \\
\hline \multicolumn{10}{|l|}{ The Republic of } \\
\hline Tatarstan & 6 & 0.886 & 64 & 2 & 23 & 27 & 17 & 43 & 40 \\
\hline Vologodskaya & 7 & 0.897 & 30 & 23 & 16 & 10 & 6 & 41 & 70 \\
\hline Moskovskaya & 8 & 0.902 & 9 & 28 & 8 & 14 & 40 & 24 & 43 \\
\hline Nizhegorodskaya & 9 & 0.907 & 2 & 72 & 52 & 16 & 9 & 29 & 18 \\
\hline \multicolumn{10}{|l|}{ The Republic of } \\
\hline Bashkortostan & 10 & 0.923 & 4 & 7 & 3 & 35 & 38 & 63 & 42 \\
\hline \multicolumn{10}{|l|}{ The Republic of } \\
\hline Mordovia & 11 & 0.924 & 49 & 1 & 49 & 47 & 42 & 14 & 23 \\
\hline Rostovskaya & 12 & 0.944 & 44 & 21 & 4 & 31 & 25 & 46 & 21 \\
\hline Lipetskaya & 13 & 0.949 & 42 & 55 & 21 & 25 & 5 & 5 & 73 \\
\hline Permskaya & 14 & 0.953 & 10 & 35 & 26 & 11 & 11 & 69 & 67 \\
\hline Moscow city & 15 & 0.959 & 76 & 34 & 1 & 1 & 1 & 85 & 26 \\
\hline Tomskaya & 16 & 0.976 & 7 & 40 & 7 & 3 & 37 & 77 & 54 \\
\hline Leningradskaya & 17 & 0.977 & 11 & 58 & 10 & 9 & 50 & 26 & 72 \\
\hline Kaluzhskaya & 18 & 0.979 & 26 & 36 & 20 & 18 & 13 & 47 & 71 \\
\hline Krasnodarsky krai & 19 & 0.986 & 8 & 24 & 12 & 26 & 35 & 67 & 56 \\
\hline \multicolumn{10}{|l|}{ The Republic of } \\
\hline Chuvash & 20 & 0.988 & 18 & 46 & 64 & 33 & 27 & 23 & 3 \\
\hline Samarskaya & 21 & 0.992 & 28 & 63 & 36 & 8 & 18 & 66 & 60 \\
\hline Kaliningradskaya & 22 & 0.992 & 45 & 68 & 29 & 6 & 12 & 72 & 36 \\
\hline Saratovskaya & 23 & 1.022 & 53 & 13 & 35 & 63 & 26 & 20 & 39 \\
\hline Tverskaya & 24 & 1.023 & 34 & 48 & 67 & 53 & 20 & 25 & 3 \\
\hline Voronezhskaya & 25 & 1.037 & 17 & 67 & 56 & 50 & 28 & 27 & 33 \\
\hline Nenetskiy AO & 26 & 1.04 & 75 & 11 & 2 & 4 & 58 & 8 & 83 \\
\hline Arkhangelskaya & 27 & 1.049 & 16 & 27 & 33 & 38 & 49 & 18 & 76 \\
\hline Penzenskaya & 28 & 1.055 & 15 & 30 & 74 & 67 & 36 & 1 & 29 \\
\hline Smolenskaya & 29 & 1.058 & 38 & 62 & 45 & 51 & 10 & 55 & 45 \\
\hline Ryazanskaya & 30 & 1.06 & 70 & 57 & 58 & 49 & 15 & 7 & 66 \\
\hline \multicolumn{10}{|l|}{ The Republic of } \\
\hline Khakasia & 31 & 1.06 & 6 & 56 & 24 & 30 & 54 & 59 & 49 \\
\hline \multicolumn{10}{|l|}{ The Republic of } \\
\hline Adygeya & 32 & 1.062 & 29 & 10 & 79 & 60 & 53 & 12 & 6 \\
\hline Kirovskaya & 33 & 1.066 & 5 & 49 & 72 & 58 & 48 & 13 & 31 \\
\hline Murmanskaya & 34 & 1.073 & 51 & 22 & 39 & 48 & 19 & 42 & 79 \\
\hline Kemerovskaya & 35 & 1.078 & 27 & 33 & 25 & 55 & 16 & 52 & 78 \\
\hline Kostromskaya & 36 & 1.078 & 48 & 53 & 66 & 59 & 34 & 17 & 28 \\
\hline Volgogradskaya & 37 & 1.095 & 59 & 79 & 51 & 15 & 32 & 61 & 41 \\
\hline Orenburgskaya & 38 & 1.105 & 22 & 60 & 42 & 28 & 55 & 56 & 57 \\
\hline Yamal-Nenets AO & 39 & 1.11 & 25 & 5 & 17 & 7 & 44 & 53 & 88 \\
\hline Hanty-Mansi AO & 40 & 1.113 & 61 & 9 & 5 & 5 & 14 & 79 & 87 \\
\hline Stavropolsky krai & 41 & 1.113 & 36 & 78 & 18 & 57 & 23 & 70 & 15 \\
\hline \multicolumn{10}{|l|}{ The Republic of } \\
\hline Buryatia & 42 & 1.117 & 12 & 32 & 13 & 61 & 62 & 54 & 48 \\
\hline Chukotsky AO & 43 & 1.117 & 89 & 3 & 62 & 13 & 56 & 22 & 80 \\
\hline
\end{tabular}




\begin{tabular}{|c|c|c|c|c|c|c|c|c|c|}
\hline \multirow[b]{3}{*}{ Region } & \multirow{3}{*}{$\begin{array}{l}\text { Investment } \\
\text { risk rating } \\
\text { in } 2003\end{array}$} & \multirow{3}{*}{$\begin{array}{l}\text { Index of } \\
\text { investment } \\
\text { risk }\end{array}$} & \multicolumn{7}{|c|}{ Seven components of investment risk } \\
\hline & & & \multirow{2}{*}{$\begin{array}{l}\text { Leg } \\
\text { al }\end{array}$} & \multirow{2}{*}{$\begin{array}{l}\text { Polit } \\
\text { ical }\end{array}$} & \multirow{2}{*}{$\begin{array}{l}\text { Econo } \\
\text { mic }\end{array}$} & \multirow{2}{*}{$\begin{array}{l}\text { Fina } \\
\text { ncial }\end{array}$} & \multirow{2}{*}{$\begin{array}{l}\text { Soc } \\
\text { ial } \\
\end{array}$} & \multirow{2}{*}{$\begin{array}{l}\text { Crimi } \\
\text { nal }\end{array}$} & \multirow{2}{*}{$\begin{array}{l}\text { Ecolo } \\
\text { gical }\end{array}$} \\
\hline & & & & & & & & & \\
\hline $\begin{array}{l}\text { The Republic of } \\
\text { Udmurtia }\end{array}$ & 44 & 1.121 & 57 & 19 & 65 & 17 & 76 & 30 & 53 \\
\hline Khabarovsky krai & 45 & 1.123 & 13 & 37 & 38 & 37 & 24 & 82 & 68 \\
\hline Pskovskaya & 46 & 1.127 & 39 & 52 & 34 & 34 & 80 & 34 & 13 \\
\hline \multicolumn{10}{|l|}{ The Republic of Karelia } \\
\hline & 47 & 1.129 & 55 & 43 & 30 & 39 & 57 & 50 & 65 \\
\hline Tambovskaya & 48 & 1.136 & 21 & 41 & 60 & 69 & 47 & 19 & 55 \\
\hline \multicolumn{10}{|l|}{ The Republic of Sakha } \\
\hline & 49 & 1.147 & 47 & 12 & 75 & 42 & 75 & 15 & 64 \\
\hline Kurskaya & 50 & 1.148 & 78 & 61 & 61 & 52 & 43 & 32 & 32 \\
\hline Omskaya & 51 & 1.157 & 63 & 45 & 44 & 19 & 65 & 73 & 51 \\
\hline Sverdlovskaya & 52 & 1.162 & 74 & 47 & 19 & 21 & 67 & 57 & 69 \\
\hline Amurskaya & 53 & 1.168 & 46 & 69 & 46 & 68 & 22 & 65 & 52 \\
\hline Astrakhanskaya & 54 & 1.17 & 33 & 65 & 31 & 12 & 79 & 75 & 34 \\
\hline Tumenskaya & 55 & 1.183 & 41 & 18 & 11 & 46 & 30 & 86 & 62 \\
\hline Ulyanovskaya & 56 & 1.187 & 77 & 50 & 59 & 64 & 51 & 31 & 12 \\
\hline Krasnoyarsky krai & 57 & 1.194 & 19 & 77 & 41 & 40 & 39 & 58 & 81 \\
\hline Vladimirskaya & 58 & 1.196 & 54 & 71 & 40 & 45 & 83 & 28 & 7 \\
\hline Chelyabinskaya & 59 & 1.196 & 62 & 42 & 37 & 41 & 31 & 44 & 86 \\
\hline Altay republic & 60 & 1.198 & 69 & 39 & 28 & 70 & 63 & 49 & 27 \\
\hline Tulskaya & 61 & 1.199 & 43 & 85 & 47 & 43 & 46 & 11 & 82 \\
\hline Irkutskaya & 62 & 1.209 & 66 & 73 & 27 & 44 & 33 & 76 & 77 \\
\hline Aginsk Buryat AO & 63 & 1.225 & 89 & 4 & 68 & 73 & 73 & 4 & 24 \\
\hline Novosibirskaya & 64 & 1.231 & 14 & 16 & 32 & 29 & 82 & 83 & 30 \\
\hline Primorsky krai & 65 & 1.242 & 65 & 83 & 53 & 32 & 41 & 80 & 59 \\
\hline Bryanskaya & 66 & 1.255 & 23 & 66 & 76 & 65 & 21 & 36 & 85 \\
\hline Chitinskaya & 67 & 1.263 & 37 & 31 & 81 & 62 & 52 & 71 & 61 \\
\hline Kurganskaya & 68 & 1.271 & 68 & 54 & 71 & 66 & 68 & 64 & 14 \\
\hline \multicolumn{10}{|l|}{ The Republic of Mari El } \\
\hline & 69 & 1.329 & 32 & 81 & 80 & 78 & 59 & 35 & 10 \\
\hline \multicolumn{10}{|l|}{ The Republic of } \\
\hline Kabardino Balkaria & 70 & 1.332 & 60 & 82 & 43 & 84 & 64 & 6 & 5 \\
\hline Sakhalinskaya & 71 & 1.341 & 79 & 80 & 22 & 56 & 81 & 68 & 46 \\
\hline Komi-Perm AO & 72 & 1.342 & 67 & 25 & 69 & 85 & 61 & 9 & 9 \\
\hline Ivanovskaya & 73 & 1.38 & 31 & 64 & 73 & 71 & 87 & 37 & 17 \\
\hline Altaisky krai & 74 & 1.387 & 35 & 84 & 54 & 75 & 84 & 51 & 47 \\
\hline The Republic of Komi & 75 & 1.419 & 72 & 59 & 50 & 54 & 74 & 78 & 84 \\
\hline Jewish $A O$ & 76 & 1.419 & 56 & 20 & 82 & 81 & 29 & 84 & 38 \\
\hline Evenkskiy AO & 77 & 1.435 & 81 & 15 & 86 & 74 & 78 & 3 & 58 \\
\hline \\
\hline Kalmykia & 78 & 1.448 & 50 & 38 & 88 & 76 & 71 & 48 & 20 \\
\hline \multicolumn{10}{|l|}{ The Republic of North } \\
\hline Osetia & 79 & 1.449 & 20 & 70 & 55 & 80 & 45 & 87 & 22 \\
\hline Tajmyr AO & 80 & 1.474 & 89 & 17 & 78 & 36 & 60 & 10 & 89 \\
\hline Magadanskaya & 81 & 1.525 & 80 & 51 & 83 & 72 & 85 & 62 & 63 \\
\hline Kamchatskaya & 82 & 1.563 & 83 & 75 & 84 & 79 & 66 & 74 & 37 \\
\hline The Republic of Tyva & 83 & 1.604 & 71 & 8 & 70 & 86 & 77 & 81 & 25 \\
\hline
\end{tabular}




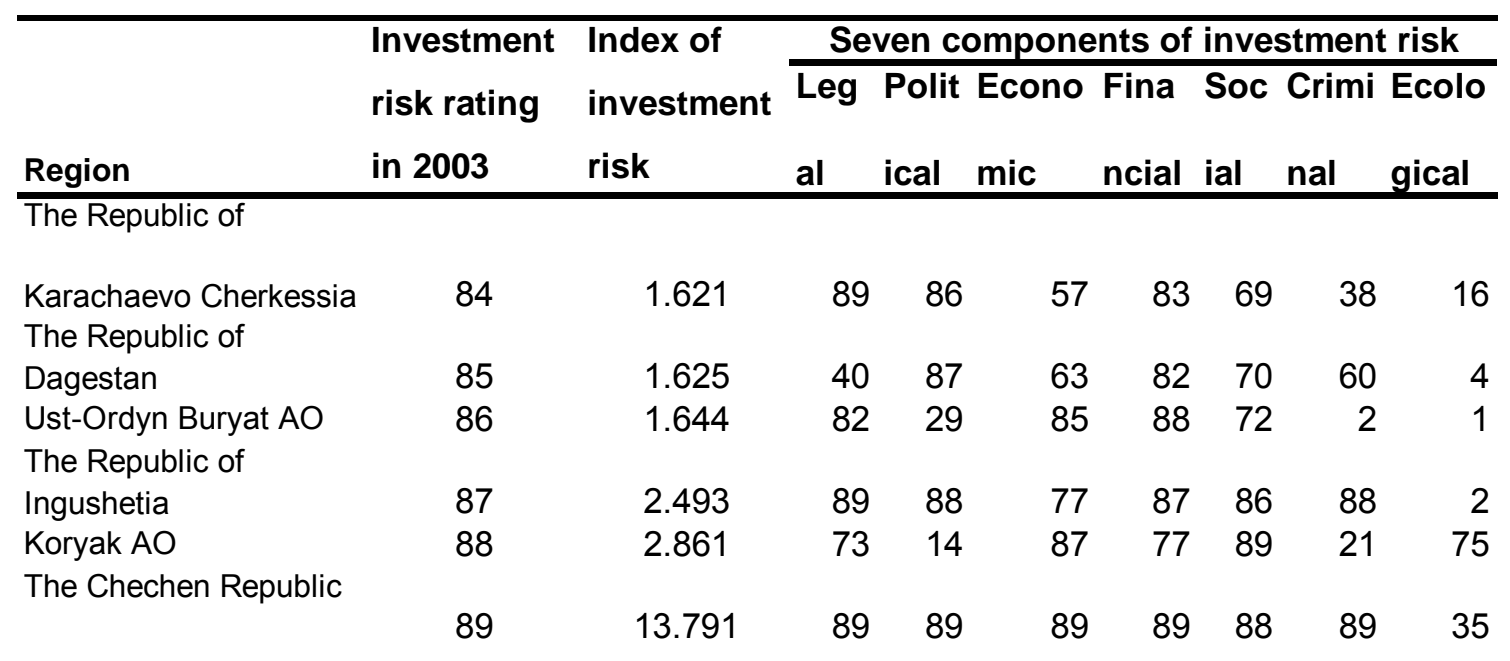

Table 3 Investment Potential in 2003

\begin{tabular}{|c|c|c|c|c|c|c|c|c|c|c|}
\hline \multirow[b]{2}{*}{ Region } & \multirow{2}{*}{$\begin{array}{l}\text { Investment } \\
\text { potential } \\
\text { rating } \\
2003\end{array}$} & \multirow{2}{*}{$\begin{array}{l}\text { Share in } \\
\text { overall } \\
\text { in potential } \\
\text { of Russia }\end{array}$} & \multicolumn{8}{|c|}{ Eight components of investment potential } \\
\hline & & & $\begin{array}{l}\text { Lab } \\
\text { or }\end{array}$ & $\begin{array}{l}\text { Cons } \\
\text { umer }\end{array}$ & $\begin{array}{l}\text { Produ } \\
\text { ction }\end{array}$ & $\begin{array}{l}\text { Finan } \\
\text { cial }\end{array}$ & $\begin{array}{l}\text { Institu } \\
\text { tional }\end{array}$ & $\begin{array}{l}\text { Innov } \\
\text { ation }\end{array}$ & $\begin{array}{l}\text { Infrastr } \\
\text { ucture }\end{array}$ & $\begin{array}{l}\text { Reso } \\
\text { urces }\end{array}$ \\
\hline Novgorodskaya & 65 & 0.433 & 66 & 65 & 56 & 64 & 57 & 48 & 30 & 79 \\
\hline Yaroslavskaya & 33 & 0.803 & 31 & 34 & 33 & 35 & 26 & 25 & 27 & 80 \\
\hline \multicolumn{11}{|l|}{ Saint Petersburg } \\
\hline city & 2 & 6.572 & 2 & 3 & 5 & 4 & 2 & 3 & 1 & 89 \\
\hline Belgorodskaya & 25 & 1.105 & 36 & 31 & 27 & 41 & 36 & 41 & 9 & 9 \\
\hline Orlovskaya & 58 & 0.516 & 55 & 56 & 57 & 57 & 62 & 38 & 21 & 76 \\
\hline \multicolumn{11}{|l|}{ The Republic of } \\
\hline Tatarstan & 9 & 2.049 & 10 & 9 & 7 & 8 & 7 & 10 & 35 & 34 \\
\hline Vologodskaya & 39 & 0.73 & 46 & 35 & 19 & 27 & 39 & 39 & 63 & 62 \\
\hline Moskovskaya & 3 & 4.511 & 3 & 2 & 3 & 3 & 3 & 2 & 4 & 48 \\
\hline Nizhegorodskaya & 6 & 2.239 & 6 & 10 & 15 & 15 & 9 & 4 & 33 & 57 \\
\hline \multicolumn{11}{|l|}{ The Republic of } \\
\hline Bashkortostan & 15 & 1.822 & 12 & 8 & 10 & 6 & 18 & 14 & 47 & 25 \\
\hline \multicolumn{11}{|l|}{ The Republic of } \\
\hline Mordovia & 62 & 0.452 & 53 & 68 & 55 & 60 & 69 & 47 & 34 & 66 \\
\hline Rostovskaya & 12 & 1.969 & 5 & 7 & 16 & 12 & 6 & 11 & 13 & 29 \\
\hline Lipetskaya & 38 & 0.74 & 47 & 38 & 21 & 31 & 53 & 65 & 14 & 73 \\
\hline Permskaya & 11 & 1.97 & 22 & 14 & 14 & 11 & 16 & 12 & 58 & 5 \\
\hline Moscow city & 1 & 17.781 & 1 & 1 & 1 & 1 & 1 & 1 & 2 & 89 \\
\hline Tomskaya & 45 & 0.681 & 48 & 37 & 37 & 33 & 41 & 22 & 70 & 28 \\
\hline Leningradskaya & 21 & 1.228 & 29 & 36 & 18 & 32 & 23 & 6 & 5 & 52 \\
\hline Kaluzhskaya & 40 & 0.726 & 40 & 55 & 48 & 55 & 44 & 15 & 17 & 71 \\
\hline Krasnodarsky krai & 10 & 2.017 & 4 & 5 & 12 & 9 & 5 & 27 & 6 & 30 \\
\hline The Republic of & & & & & & & & & & \\
\hline Chuvashia & 52 & 0.615 & 39 & 53 & 47 & 53 & 49 & 36 & 19 & 83 \\
\hline
\end{tabular}




\begin{tabular}{|c|c|c|c|c|c|c|c|c|c|c|}
\hline \multirow[b]{2}{*}{ Region } & \multirow{2}{*}{$\begin{array}{l}\text { Investmen } \\
\text { potential } \\
\text { rating } \\
2003\end{array}$} & \multirow{2}{*}{ 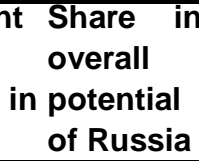 } & \multicolumn{8}{|c|}{ Eight components of investment potential } \\
\hline & & & $\begin{array}{l}\text { Lab } \\
\text { or }\end{array}$ & $\begin{array}{l}\text { Cons } \\
\text { umer }\end{array}$ & $\begin{array}{l}\text { Produ } \\
\text { ction }\end{array}$ & $\begin{array}{l}\text { Finan } \\
\text { cial }\end{array}$ & $\begin{array}{l}\text { Institu } \\
\text { tional }\end{array}$ & $\begin{array}{l}\text { Innov } \\
\text { ation }\end{array}$ & $\begin{array}{l}\text { Infrastr } \\
\text { ucture }\end{array}$ & $\begin{array}{l}\text { Reso } \\
\text { urces }\end{array}$ \\
\hline Samarskaya & 8 & 2.16 & 7 & 6 & 6 & 10 & 8 & 7 & 20 & 45 \\
\hline Kaliningradskaya & 37 & 0.741 & 52 & 58 & 53 & 52 & 29 & 54 & 3 & 40 \\
\hline Saratovskaya & 20 & 1.262 & 9 & 21 & 23 & 21 & 19 & 19 & 23 & 35 \\
\hline Tverskaya & 44 & 0.682 & 37 & 48 & 41 & 47 & 33 & 29 & 26 & 63 \\
\hline Voronezhskaya & 28 & 1.032 & 23 & 22 & 29 & 30 & 28 & 16 & 18 & 55 \\
\hline Nenetskiy AO & 85 & 0.091 & 86 & 83 & 74 & 78 & 81 & 83 & 86 & 69 \\
\hline Arkhangelskaya & 43 & 0.685 & 41 & 33 & 43 & 39 & 42 & 46 & 66 & 19 \\
\hline Penzenskaya & 49 & 0.628 & 27 & 46 & 51 & 51 & 55 & 35 & 39 & 49 \\
\hline Smolenskaya & 54 & 0.565 & 51 & 47 & 45 & 56 & 56 & 57 & 15 & 74 \\
\hline Ryazanskaya & 48 & 0.628 & 42 & 49 & 40 & 45 & 46 & 42 & 22 & 56 \\
\hline \multicolumn{11}{|l|}{ The Republic of } \\
\hline $\begin{array}{l}\text { Khakasia } \\
\text { The Republic of }\end{array}$ & The Republic of & 0.31 & 71 & 70 & 69 & 71 & 71 & 75 & 67 & 27 \\
\hline Adygeya & 75 & 0.254 & 75 & 73 & 76 & 76 & 73 & 79 & 25 & 86 \\
\hline Kirovskaya & 55 & 0.56 & 34 & 45 & 44 & 42 & 47 & 51 & 64 & 53 \\
\hline Murmanskaya & 32 & 0.926 & 43 & 40 & 38 & 36 & 37 & 30 & 31 & 13 \\
\hline Kemerovskaya & 13 & 1.95 & 16 & 11 & 13 & 16 & 24 & 26 & 57 & 4 \\
\hline Kostromskaya & 69 & 0.344 & 68 & 69 & 64 & 69 & 65 & 49 & 59 & 72 \\
\hline Volgogradskaya & 22 & 1.175 & 19 & 16 & 20 & 17 & 22 & 20 & 43 & 32 \\
\hline Orenburgskaya & 30 & 0.957 & 24 & 27 & 22 & 29 & 35 & 55 & 44 & 18 \\
\hline Yamal-Nenets AO & 16 & 1.682 & 67 & 41 & 9 & 13 & 25 & 73 & 80 & 2 \\
\hline Hanty-Mansi AO & 5 & 2.554 & 26 & 15 & 2 & 2 & 27 & 37 & 81 & 6 \\
\hline Stavropolsky krai & 27 & 1.035 & 14 & 19 & 31 & 24 & 20 & 32 & 51 & 41 \\
\hline \multicolumn{11}{|l|}{ The Republic of } \\
\hline Buryatia & 57 & 0.521 & 57 & 54 & 62 & 58 & 61 & 66 & 74 & 15 \\
\hline Chukotsky AO & 70 & 0.339 & 81 & 81 & 77 & 73 & 82 & 81 & 78 & 14 \\
\hline \multicolumn{11}{|l|}{ The Republic of } \\
\hline Udmurtia & 41 & 0.725 & 32 & 39 & 28 & 37 & 30 & 40 & 41 & 60 \\
\hline Khabarovsky krai & 23 & 1.143 & 20 & 29 & 25 & 22 & 34 & 34 & 61 & 10 \\
\hline Pskovskaya & 63 & 0.443 & 59 & 62 & 67 & 67 & 63 & 68 & 12 & 77 \\
\hline \multicolumn{11}{|l|}{ The Republic of } \\
\hline Karelia & 60 & 0.473 & 65 & 57 & 54 & 61 & 54 & 62 & 36 & 36 \\
\hline Tambovskaya & 59 & 0.515 & 49 & 44 & 58 & 54 & 64 & 43 & 32 & 67 \\
\hline \multicolumn{11}{|l|}{ The Republic of } \\
\hline Sakha & 19 & 1.372 & 64 & 32 & 26 & 23 & 43 & 44 & 85 & 1 \\
\hline Kurskaya & 35 & 0.766 & 45 & 51 & 42 & 49 & 51 & 53 & 7 & 21 \\
\hline Omskaya & 31 & 0.937 & 25 & 20 & 34 & 20 & 21 & 21 & 53 & 43 \\
\hline Sverdlovskaya & 4 & 2.771 & 8 & 4 & 4 & 5 & 4 & 5 & 48 & 8 \\
\hline Amurskaya & 50 & 0.617 & 56 & 61 & 60 & 62 & 66 & 71 & 65 & 12 \\
\hline Astrakhanskaya & 56 & 0.536 & 60 & 52 & 59 & 44 & 52 & 59 & 46 & 26 \\
\hline Tumenskaya & 34 & 0.801 & 38 & 25 & 50 & 28 & 11 & 23 & 62 & 51 \\
\hline Ulyanovskaya & 46 & 0.649 & 50 & 42 & 46 & 50 & 48 & 18 & 42 & 54 \\
\hline
\end{tabular}




\begin{tabular}{|c|c|c|c|c|c|c|c|c|c|c|}
\hline \multirow[b]{2}{*}{ Region } & \multirow{2}{*}{$\begin{array}{l}\text { Investmen } \\
\text { potential } \\
\text { rating } \\
2003\end{array}$} & \multirow{2}{*}{$\begin{array}{l}\text { Share in } \\
\text { overall } \\
\text { in potential } \\
\text { of Russia }\end{array}$} & \multicolumn{8}{|c|}{ Eight components of investment potential } \\
\hline & & & $\begin{array}{l}\text { Lab } \\
\text { or }\end{array}$ & $\begin{array}{l}\text { Cons } \\
\text { umer }\end{array}$ & $\begin{array}{l}\text { Produ } \\
\text { ction }\end{array}$ & $\begin{array}{l}\text { Finan } \\
\text { cial }\end{array}$ & $\begin{array}{l}\text { Institu } \\
\text { tional }\end{array}$ & $\begin{array}{l}\text { Innov } \\
\text { ation }\end{array}$ & $\begin{array}{l}\text { Infrastr } \\
\text { ucture }\end{array}$ & $\begin{array}{l}\text { Reso } \\
\text { urces }\end{array}$ \\
\hline Krasnoyarsky krai & 7 & 2.175 & 13 & 13 & 11 & 7 & 14 & 17 & 75 & 3 \\
\hline Vladimirskaya & 36 & 0.75 & 30 & 50 & 39 & 43 & 32 & 24 & 16 & 70 \\
\hline Chelyabinskaya & 14 & 1.886 & 11 & 12 & 8 & 14 & 12 & 9 & 24 & 24 \\
\hline Altay republic & 83 & 0.126 & 78 & 79 & 82 & 80 & 78 & 80 & 72 & 50 \\
\hline Tulskaya & 29 & 0.977 & 33 & 30 & 30 & 38 & 31 & 13 & 8 & 61 \\
\hline Irkutskaya & 17 & 1.551 & 17 & 18 & 17 & 18 & 17 & 31 & 73 & 7 \\
\hline Aginsk Buryat $\mathrm{AO}$ & 88 & 0.052 & 84 & 84 & 87 & 84 & 88 & 82 & 83 & 85 \\
\hline Novosibirskaya & 18 & 1.373 & 15 & 17 & 24 & 19 & 13 & 8 & 50 & 37 \\
\hline Primorsky krai & 24 & 1.126 & 18 & 24 & 35 & 25 & 10 & 33 & 45 & 17 \\
\hline Bryanskaya & 47 & 0.644 & 28 & 43 & 52 & 48 & 50 & 50 & 10 & 68 \\
\hline Chitinskaya & 51 & 0.616 & 63 & 63 & 66 & 59 & 60 & 64 & 69 & 11 \\
\hline \multirow{2}{*}{\multicolumn{11}{|c|}{ The Republic of }} \\
\hline & & & & & & & & & & \\
\hline Mari El & 71 & 0.32 & 70 & 71 & 70 & 72 & 67 & 61 & 54 & 44 \\
\hline \multicolumn{11}{|l|}{ The Republic of } \\
\hline $\begin{array}{l}\text { Kabardino Balkaria } \\
\text { Sakhalinskaya }\end{array}$ & $\begin{array}{l}68 \\
61\end{array}$ & $\begin{array}{l}0.403 \\
0.472\end{array}$ & $\begin{array}{l}61 \\
69\end{array}$ & $\begin{array}{l}59 \\
64\end{array}$ & $\begin{array}{l}68 \\
49\end{array}$ & $\begin{array}{l}65 \\
46\end{array}$ & $\begin{array}{l}72 \\
40\end{array}$ & $\begin{array}{l}69 \\
56\end{array}$ & $\begin{array}{l}28 \\
55\end{array}$ & $\begin{array}{l}47 \\
39\end{array}$ \\
\hline Komi-Perm AO & 87 & 0.061 & 82 & 82 & 85 & 85 & 83 & 77 & 84 & 82 \\
\hline Ivanovskaya & 66 & 0.426 & 44 & 67 & 63 & 66 & 58 & 60 & 37 & 84 \\
\hline Altaisky krai & 26 & 1.037 & 21 & 23 & 32 & 34 & 15 & 28 & 52 & 23 \\
\hline \multicolumn{11}{|l|}{ The Republic of } \\
\hline Komi & 42 & 0.69 & 54 & 28 & 36 & 26 & 45 & 52 & 79 & 22 \\
\hline Jewish AO & 78 & 0.19 & 80 & 77 & 78 & 81 & 77 & 74 & 60 & 38 \\
\hline Evenkskiy AO & 84 & 0.094 & 87 & 88 & 88 & 89 & 89 & 89 & 89 & 31 \\
\hline The Republic of & 82 & 0.138 & 76 & 78 & 80 & 74 & 76 & 76 & 76 & 64 \\
\hline \multicolumn{11}{|l|}{ The Republic of } \\
\hline North Osetia & 64 & 0.435 & 58 & 66 & 72 & 68 & 70 & 70 & 11 & 58 \\
\hline Tajmyr AO & 77 & 0.235 & 85 & 85 & 86 & 83 & 85 & 85 & 71 & 16 \\
\hline Magadanskaya & 72 & 0.311 & 74 & 75 & 73 & 75 & 74 & 72 & 82 & 20 \\
\hline Kamchatskaya & 74 & 0.269 & 73 & 72 & 71 & 70 & 68 & 58 & 68 & 42 \\
\hline \multicolumn{11}{|l|}{ The Republic of } \\
\hline Tyva & 81 & 0.138 & 79 & 76 & 81 & 79 & 79 & 78 & 88 & 33 \\
\hline \multicolumn{11}{|l|}{$\begin{array}{l}\text { The Republic of } \\
\text { Karachaevo }\end{array}$} \\
\hline Cherkessia & 76 & 0.239 & 72 & 74 & 75 & 77 & 75 & 67 & 56 & 59 \\
\hline \multicolumn{11}{|l|}{ The Republic of } \\
\hline Dagestan & 53 & 0.613 & 35 & 26 & 61 & 40 & 38 & 63 & 40 & 46 \\
\hline \multicolumn{11}{|l|}{ Ust-Ordyn Buryat } \\
\hline $\mathrm{AO}$ & 86 & 0.066 & 83 & 86 & 84 & 87 & 84 & 89 & 77 & 81 \\
\hline \multicolumn{11}{|l|}{ The Republic of } \\
\hline Ingushetia & 79 & 0.177 & 77 & 80 & 83 & 82 & 80 & 84 & 38 & 87 \\
\hline Koryak AO & 89 & 0.047 & 88 & 87 & 79 & 86 & 86 & 89 & 87 & 78 \\
\hline \multicolumn{11}{|l|}{ The Chechen } \\
\hline Republic & 80 & 0.155 & 89 & 89 & 89 & 88 & 87 & 89 & 29 & 75 \\
\hline
\end{tabular}




\section{Appendix C \\ Key Elements of the GAMS code for creating the Regional Input-Output Tables}

Below are the key elements of the GAMS code for creating the regional input-output tables:

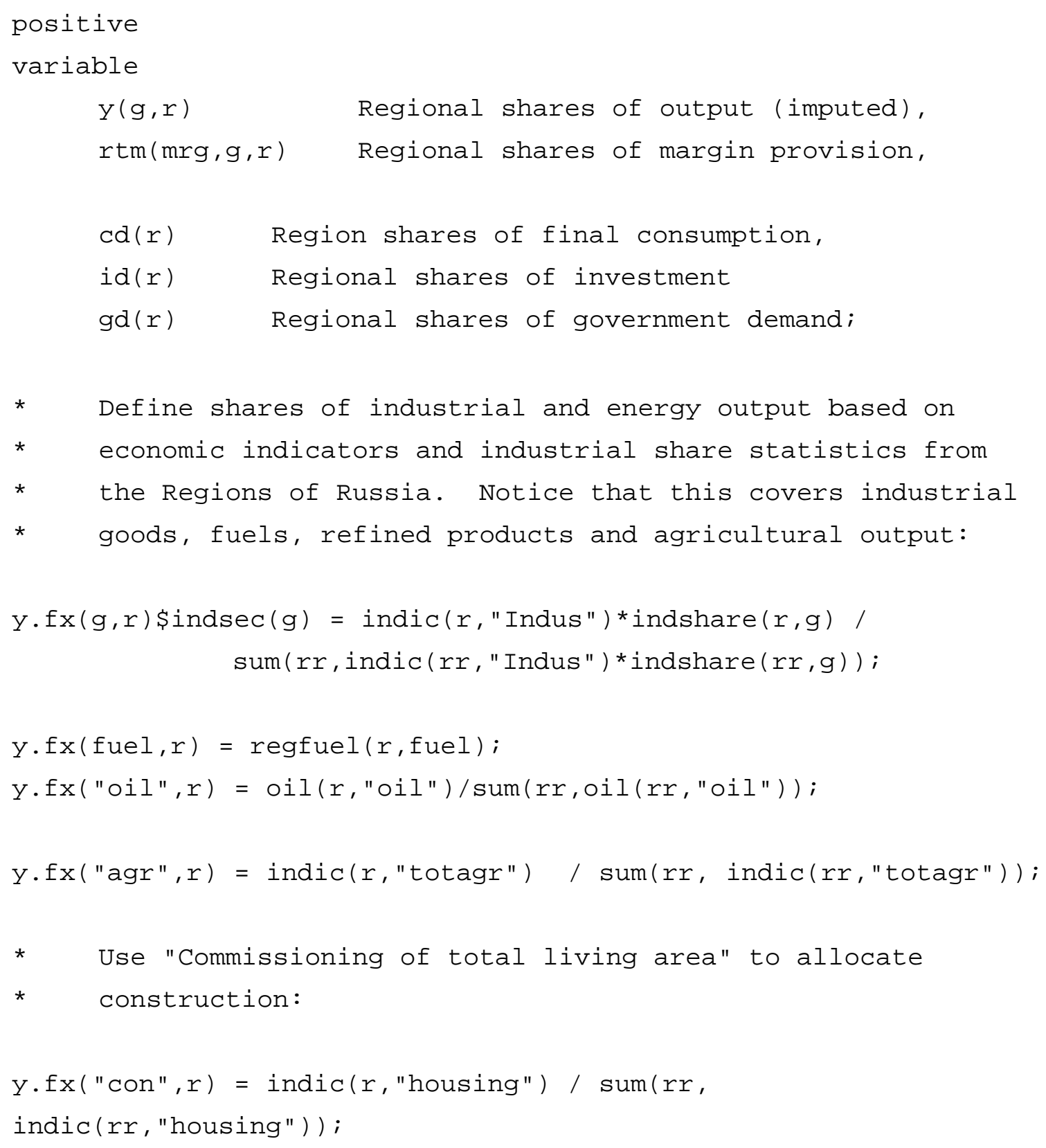


* Use industrial output to allocate other goods and services:

$y \cdot f x($ "oth", $r)=$ indic $(r$, "indus" $) / \operatorname{sum}(r r$, indic $(r r$, "indus" $))$;

* Consumptino demand levels are assumed proportional to

* expenditure per capita times population:

$\operatorname{cd} . l(r)=\operatorname{indic}(r, " \operatorname{exppc} ") * \operatorname{indic}(r$, "pop" $) /$

$\operatorname{sum}(r r, \operatorname{indic}(r r$, "exppc" $)$ *indic $(r r$, "pop" $))$;

* Investment shares are likewise based on indicator data:

id.l$(r)=\operatorname{indic}(r$, "invest")/sum $(r r, \operatorname{indic}(r r$, "invest" $))$;

* Government demand is assumed proportional to GRP:

$\operatorname{gd.l}(r)=\operatorname{indic}(r, \operatorname{grp} ") / \operatorname{sum}(r r, \operatorname{indic}(r r, " g r p "))$;

Here, then, is the system of linear equations which determine service sector supplies -- note that these equations are defined in terms of submatrices taken from the national input-output table, hence we retain the input-output characteristics from the national table when setting up the regional statistics, and we only calibrate regional shares of output:

positive

variable $a(g, r) \quad$ Armington activity level;

equations pamkt, pdmkt, pmmkt;

* Armington composite goods supply and demand:

$\operatorname{pamkt}(g, r) \$(a \cdot l o(g, r)$ ne a.up $(g, r)) \ldots$

$a(g, r) * a \theta_{-}(g)=e=\operatorname{sum}\left(g g, i d \theta_{-}(g, g g) * y(g g, r)\right)$

$+a c \theta_{-}(g) * c d . l(r)+a i \theta_{-}(g) * i d . l(r)+a g \theta_{-}(g) * g d . l(r)$; 
* Market for domestic supply:

$\operatorname{pdmkt}(g, r) \$(y \cdot l o(g, r)$ ne $y \cdot u p(g, r)) \ldots$

$$
\begin{aligned}
& \left(d \Theta_{-}(g)+s \Theta_{-}(g)\right){ }^{*} y(g, r)=e= \\
& \quad \operatorname{sum}\left((m r g, g g), r \operatorname{rmd} \Theta_{-}(g, m r g, g g){ }^{*} r t m(m r g, g g, r)\right)+
\end{aligned}
$$

ado_(g)*a $(g, r)$;

* Market for imported supply:

pmmkt $(m r g, g, r) \$(r t m . l o(m r g, g, r)$ ne $r t m . u p(m r g, g, r)) \ldots$

$$
\begin{aligned}
\operatorname{rtm}(m r g, g, r) & * r t m \Theta_{-}(m r g, g)=e= \\
\operatorname{sum} & \left(g g, y(g g, r) * m d \Theta_{-}(m r g, g, g g)\right) \\
& +y(g, r) * \text { ei.l }(r, g) * m d \Theta_{-}(m r g, g, " x ") \\
& +c d . l(r) * m d \Theta_{-}(m r g, g, " c ") \\
& +i d . l(r) * m d \Theta_{-}(m r g, g, " i ") \\
& +g d . l(r) * m d \theta_{-}(m r g, g, " g ")
\end{aligned}
$$

After having constructed input-output tables, we then integrate and rebalance trade statistics to match these production and consumption statistics. 